SJ Quinney College of Law, University of Utah Utah Law Digital Commons

\title{
Toward a National Conservation Network Act: Transforming Landscape Conservation on the Public Lands into Law
}

Robert B. Keiter

S.J. Quinney College of Law, University of Utah, robert.keiter@law.utah.edu

Follow this and additional works at: https://dc.law.utah.edu/scholarship

Part of the Environmental Law Commons, and the Natural Resources Law Commons

\section{Recommended Citation}

Keiter, Robert B., Toward a National Conservation Network Act: Transforming Landscape Conservation on the Public Lands into Law, Harvard Environmental Law Review, Forthcoming.

This Article is brought to you for free and open access by the Utah Law Scholarship at Utah Law Digital Commons. It has been accepted for inclusion in Utah Law Faculty Scholarship by an authorized administrator of Utah Law Digital Commons. For more information, please contact 


\title{
TOWARD A NATIONAL CONSERVATION NETWORK ACT: TRANSFORMING LANDSCAPE CONSERVATION ON THE PUBLIC LANDS INTO LAW
}

\author{
Robert B. Keiter ${ }^{*}$
}

The United States has made a remarkable commitment to nature conservation on the federal public lands. The country's existing array of national parks, wilderness areas, national monuments, wildlife refuges, and other protective designations encompasses roughly 150 million acres, or nearly 40 percent of the "lower 48" federal estate. A robust land trust movement has protected another 56 million acres of privately owned lands. Advances in scientific knowledge reveal that these protected enclaves, standing alone, are insufficient to protect native ecosystems and at-risk wildlife from climate change impacts and unrelenting development pressures. Abetted by existing law, conservation policy is now focusing on the larger landscape to preserve biological diversity and to promote ecological resilience as principal management goals. This growing emphasis on landscape-scale conservation is evident in various protected area complexes that have arisen organically across the federal estate in places as diverse as the Greater Yellowstone Ecosystem, California's Mojave Desert, and Colorado's San Luis Valley.

To fully capitalize on these ad hoc developments, this article makes the case for a new National Conservation Network Act to legitimize and expand upon these protected areas. It first reviews the origins and evolution of the nation's protected land systems and related nature conservation strategies, and then identifies the scientific and legal developments underlying landscape-scale conservation strategies. Next, it highlights several emergent protected area complexes evident on the public lands, explaining their diverse origins and important conservation contributions. It concludes by proposing new legislation that would place a statutory umbrella over these protected complexes, mandate effective interagency coordination within them, enlist private lands as voluntary "affiliates" in these conservation efforts, and establish new wildlife corridor and restoration area designations. The proposed law would validate the current movement toward landscape conservation, and thus amplify the federal commitment to nature conservation to meet the challenges looming ahead.

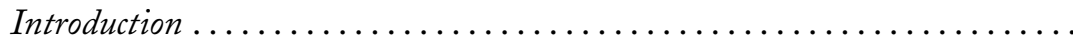

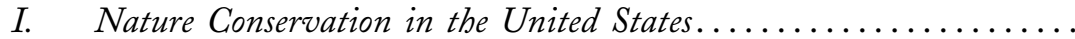

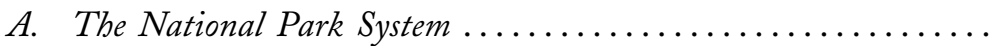

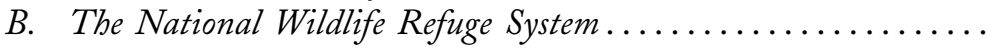

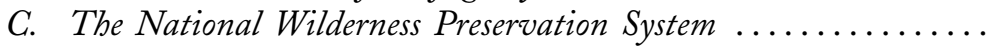

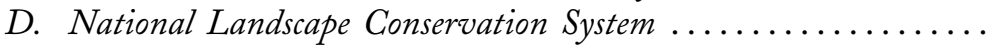

E. National Forest Roadless Areas .........................

Wallace Stegner Professor of Law, University Distinguished Professor, and Director, Wallace Stegner Center for Land, Resources and the Environment, University of Utah S.J. Quinney College of Law. My sincere thanks to the Quinney College of Law's Albert and Elaine Borchard Fund for Faculty Excellence, to John Ruple and Myrl Duncan, who thoughtfully reviewed earlier versions of this Article, to the late Fred Cheever and Justin Pidot and their Advanced Natural Resources Law class at the University of Denver Sturm College of Law, and to my Behle and Quinney Research Fellows-Hannah Follender, Sheena Christman, Mitch Longson, and Haley Carmer-who provided exceptional research assistance. 
F. Other Protected Lands: Federal, State, and Tribal

Designations ................................ 79

G. Private Land Conservation: Land Trusts and Conservation

Easements ................................. 85

II. An Evolving Nature Conservation Commitment.............. 88

A. The Role of Science in Nature Conservation ............. 88

B. Law, Ecology, and Nature Conservation ................ 93

1. Congress: Setting the Nation's Conservation Policy ....... 94

2. The Agencies: Rules, Policies, and Practices ............ 97

3. The Courts: Giving Landscape Conservation Its Due ...... 101

4. Conserving Private Lands under Federal and State Law .. 104

III. Constructing a Landscape Conservation Network .............. 110

A. De Facto Landscape Conservation: The Current Ad Hoc

Approach..................................... 111

1. Greater Yellowstone Ecosystem .................... 111

2. Crown of the Continent Ecosystem .................. 114

3. The California Desert Area ...................... 116

4. Greater Grand Canyon Region ................... 117

5. Colorado's San Luis Valley ....................... 119

6. American Prairie Reserve ....................... 120

7. Northwest Forest Plan......................... 121

8. Sierra Nevada Ecosystem........................ 123

9. Elsewhere on the Public Domain ................... 125

B. A National Conservation Network: Conceiving a Statutory

Framework .................................... 127

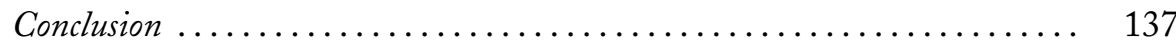

Appendix A-Federal Land Ownership and Protected Areas .......... 138

\section{INTRODUCTION}

During the past 100 years, the United States has made a remarkable commitment to nature conservation in the form of national parks, wilderness areas, national wildlife refuges, and other protective designations on the nation's public lands. This robust trend toward conserving natural landscapes is particularly evident in the western United States, where nearly half of the landscape is in federal ownership, the south Florida Everglades region, along the Appalachian Mountain chain, and elsewhere. About half of the federal estate-roughly 300 million acres-is in some form of protective status, either by congressional legislation, presidential order, or administrative rule or designation. In the lower forty-eight states, approximately 150 million acres, or nearly forty percent of 
federally owned lands, are protected from industrial activity, ${ }^{1}$ a significant number by any standard. Congress has devised four major land preservation systems for the federal estate, namely the national park, national wilderness preservation, national wildlife refuge, and national landscape conservation systems, and charged the four federal land management agencies responsible for these lands to preserve them intact. ${ }^{2}$ Moreover, a growing land trust movement has brought nature conservation to the nation's private lands as well, where 56 million acres are now safeguarded by conservation easements and other legal means, ${ }^{3}$ further reflecting the nation's protective inclinations. These trends will almost certainly continue given the broad public support that land conservation enjoys in most polls,${ }^{4}$ even as pockets of resistance remain among some western states and various rural communities.

The rationale for protecting public and private lands has evolved over time, giving rise to a growing assortment of landscape-scale conservation initiatives. In the beginning, the national parks were set aside to protect particularly scenic venues, ${ }^{5}$ the wildlife refuges to protect at-risk species, ${ }^{6}$ and wilderness areas mainly for recreational purposes. ${ }^{7}$ As time passed, it became evident that

1. See Appendix A, which contains charts showing federal land ownership and protected acreage by agency and designation.

2. Dyan Zaslowsky \& T.H. Watkins, These American Lands: Parks, Wilderness AND the Public Lands (1994). The four federal land management agencies are: National Park Service, U.S. Forest Service, U.S. Fish \& Wildlife Service, and Bureau of Land Management ("BLM"). Lands encompassed within the National Wilderness Preservation System are managed by each of these four federal agencies. Other federally protected lands include national monuments, wild and scenic river corridors, and national trails. See infra notes 84-93, 108-24 and accompanying text. BLM's National Landscape Conservation System, also known as national conservation lands, includes national monuments, national conservation areas, wild and scenic rivers, national scenic and historic trails, and wilderness study areas. See About Your National Conservation Lands, BurEAu of LAND MGMT., https://per ma.cc/6ZKN-RATC.

3. Land Tr. All., 2015 National Land Trust Census Report, https://perma.cc/ BCW8-YQKP; Ashley A. Dayer et al., Wildlife Conservation and Private Protected Areas: The Discrepancy Between Land Trust Mission Statements and Their Perceptions, 58 EnVTL. MgMT. 359, 359 (2016); see infra notes 145-159 and accompanying text.

4. See 2017 Western States Survey Interview Schedule, Colo. Coll., https://perma.cc/Y9GP7LGD; Elana Richman et al., National Poll Results: How Americans View Conservation (2017), https://perma.cc/Y86P-N6LX; Colo. Coll. State of the Rockies Project, Conservation in the West Poll, Public Lands (2015), https://perma.cc/7TBS-DC9J.

5. Alfred Runte, National Parks: The American Experience 11-12 (4th ed. 2010); Richard West Sellars, Preserving Nature in the National Parks: A History 14 (1997).

6. Robert L. Fischman, National Wildlife Refuges: Coordinating a ConservaTion System through Law 34-40 (2003).

7. See Mark Woods, Federal Wilderness Preservation in the United States: The Preservation of Wilderness?, in The Great New Wilderness Debate 131, 132 (J. Baird Callicott \& Michael P. Nelson, eds., 1998); Craig W. Allin, The Politics of Wilderness Pres- 
these enclaves also served as valuable sanctuaries for an increasing number of species whose populations were dwindling due to development and other pressures. With the maturation of the ecological sciences and the advent of conservation biology, scientists confirmed the need to establish expansive protected areas and to connect them to safeguard wildlife against habitat loss and other threats. ${ }^{8}$ The emergent realities of climate change and warmer temperatures have added urgency to these concerns. ${ }^{9}$ These insights have given rise to the related concepts of ecosystem management and landscape conservation as necessary means to preserve species and ecosystem functions vital to humankind. ${ }^{10}$ Employing this knowledge, new land conservation strategies are emerging in such diverse locations as the Greater Yellowstone Ecosystem, Montana's Glacier country, California's Mojave Desert, the Grand Canyon region, and Colorado's San Luis Valley. In short, a landscape-scale approach to nature conservation is taking shape on the public lands.

This Article makes the case for a National Conservation Network Act to acknowledge and legitimize the remarkable protected land complexes that have evolved ad hoc during the past several decades. The Article begins by examining the evolution of nature conservation efforts in the United States, focusing principally on the major role public lands play in this effort. It then explains how the rationale underlying the nation's conservation efforts has matured over time with an increasing emphasis on the critical role of science in defining preservationist goals and strategies. Next, the Article highlights several important landscape-level conservation initiatives, arguing that a piecemeal network of protected areas is de facto taking shape across large swathes of public land, and that this network is being bolstered by strategic private land conservation efforts. The Article concludes by proposing legislation to create a formal $\mathrm{Na}$ tional Conservation Network. The proposal would place the existing protected

ERVATION 76-77, 114, 129-30 (1982); see also 16 U.S.C. § 1131(a) (2012) (describing "wilderness areas" as set aside "for the use and enjoyment of the American people"); id. § 1131(c) (defining "wilderness" as an area that provides "outstanding opportunities for solitude or a primitive and unconfined type of recreation").

8. See Reed F. Noss \& Alan Y. Cooperrider, Saving Nature's Legacy: Protecting And Restoring Biodiversity 28-29 (1994); J. Michael Scott et al., The Issue of Scale in Selecting and Designing Biological Reserves, in Continental Conservation 19 (Michael E. Soulé \& John Terborgh, eds., 1999).

9. See Jonathan R. Mawdsley et al., A Review of Climate-Change Adaptation Strategies for Wildlife Management and Biodiversity Conservation, 23 Conservation Biology 1080, 1080 (2009); Céline Bellard et al., Impacts of Climate Change on the Future of Biodiversity, 15 ECOLOGY LetTERs 365, 365 (2012).

10. On emergence of the ecosystem management concept, see Robert B. KeIter, Keeping Faith with Nature: Ecosystems, Democracy, and America's Public Lands (2003); James R. Skillen, Federal Ecosystem Management: Its Rise, Fall, and AfTERLIFE (2015). For a history and analysis of the landscape conservation concept, see generally Nat'l Acad. of Sci., A Review of the Landscape Conservation CoopERATIVES (2016), https://perma.cc/WDY2-AWLW. 
area designations under a statutory umbrella, but would not change ownership or management of these areas. It calls for coordinated and accountable management of the nation's preserved lands, requires agency planners to identify potential connective wildlife corridors, affords private landowners and conservation easement holders the opportunity to affiliate with the network, and contemplates a new national restoration area designation. The goal is to promote meaningful landscape-scale conservation to meet the challenges ahead.

\section{Nature Conservation in the United States}

The American commitment to nature conservation has a long history with ties to national identity, aesthetic sensibilities, outdoor recreation, and wildlife protection. Much of the effort has focused on the nation's abundant public lands, and contrasts with the powerful utilitarian ethic that drove the country's westward march across the continent. It reflects a nation deeply devoted to saving important parts of its natural heritage yet regularly conflicted over the very notion of preservation, ${ }^{11}$ a reality that persists today. Much of what has been accomplished has occurred haphazardly, as much the result of political opportunism as any grand design. The end product reflects disparate sets of nature enclaves each designed to preserve specific areas or objects for the benefit of present and future generations, ${ }^{12}$ thus contemplating that these protected enclaves will remain undisturbed over the ages. How this has come to pass and the shape it now takes is a testament to the foresight, perseverance, and political acumen that has resulted in more than 300 million acres set aside primarily for nature conservation purposes.

\section{A. The National Park System}

With the creation of Yellowstone National Park in 1872 as a "public park or pleasuring ground," Congress endorsed the idea that some public lands should be preserved essentially in their natural state "for the benefit and enjoyment of the people." ${ }^{13}$ Motivated principally by the region's unique geysers and other extraordinary natural features, the Yellowstone legislation set the stage for Congress to preserve other scenic wonders as national parks, including Yosemite, Mount Rainier, Sequoia, Crater Lake, Glacier, and Rocky Moun-

11. See, e.g., Robert Righter, The Battle over Hetch Hetchy: America's Most Controversial Dam and the Birth of Modern Environmentalism 4-5 (2005); Mark W.T. Harvey, A Symbol of Wilderness: Echo Park and the American Conservation Movement 292-94 (2015).

12. On the enclave approach to nature conservation, see Joseph L. Sax, Perspectives Lecture: Public Land Law in the 21st Century, 4 Rocky Mtn. Min. L. Inst. § 1.02 (1999).

13. 16 U.S.C. $\S 21(2012)$. 
tain. ${ }^{14}$ Invoking the authority Congress granted him under the Antiquities Act of 1906, ${ }^{15}$ President Theodore Roosevelt established the Grand Canyon National Monument in $1908,{ }^{16}$ paving the way for subsequent presidents to use this power to expand the national park system. In 1916, in the aftermath of the high profile Hetch-Hetchy controversy that saw a dam constructed inside Yosemite National Park, Congress was convinced to bring the diverse individual parks into a new national park system and to establish the National Park Service to oversee these national treasures. ${ }^{17}$ The milestone National Park Service Organic Act directed the new Park Service to manage the national parks "to conserve the scenery and the natural and historic objects and the wild life therein and to provide for the enjoyment of the same ... by such means as will leave them unimpaired for the enjoyment of future generations." ${ }^{18}$ Though the Organic Act put an obvious premium on conservation with an eye toward future generations, the new Park Service focused on attracting visitors to these then-remote natural wonders and ensuring that they had beautiful scenery to admire.

Since then, the national park idea has evolved in terms of the type of areas included in the system. Beginning with the establishment of a National Recreation Area at Lake Mead in 1936, ${ }^{19}$ Congress has employed a potpourri of designations to add new areas to the system, including national seashores, national preserves, national lakeshores, national heritage areas, and the list goes on, each preserved from development primarily for recreational or other specific pur-

14. On the creation of the early national parks, see Alfred Runte, National Parks: The AMERican EXPERIENCE 55-57 (2d ed. 1987).

15. Pub. L. No. 59-209, 34 Stat. 225 (1906) (codified at 54 U.S.C. §§ 320301-320303 (2012)). See generally Char Miller, Landmark Decision: The Antiquities Act, Big-Stick Conservation, and the Modern State, in The Antieuities Act 64, 64-78 (David Harmon et al. eds., 2006) (describing early implementation of the Antiquities Act).

16. See Proclamation No. 794 (Jan. 11, 1908), reprinted in Proclamations And Orders ReLating to the National Park Service up to January 1, 1945, 28 (Thomas Alan Sullivan ed., 1947); Cameron v. United States, 252 U.S. 450 (1920) (sustaining President Roosevelt's designation of the Grand Canyon National Monument against legal challenge). Although President Roosevelt's 1908 proclamation left oversight of the new Grand Canyon National Monument with the Forest Service, Congress transferred the fledgling monument to the national park system in 1919. See An Act To Establish the Grand Canyon National Park in the State of Arizona, Pub. L. No. 65-277, 40 Stat. 1177 (1919). In 1932, President Herbert Hoover relied on the Antiquities Act to add more land to the park. See Proclamation No. 2022 (Dec. 22, 1932), reprinted in Proclamations and Orders Relating to the National Park Service up to January, supra, at 204.

17. See Righter, supra note 11, at 191-94; Brian E. Gray, Hetch Hetchy and the Paradoxes of Restoration, 13 Hastings W.-Nw. J. Envtl. L. \& Pol'y 211, 216-17 (2007).

18. 64 Pub. L. No. 235 (1916) (current version at 54 U.S.C.S. §§ 100101-100103 (2012)).

19. 16 U.S.C. $\S 460 \mathrm{n}(2012)$. 
poses. ${ }^{20}$ With the establishment of the Everglades National Park in $1934,{ }^{21}$ Congress began taking wilderness and ecological characteristics into account when making new national park designations, moving beyond scenery as the principal consideration for adding new areas to the system. In 1980, with the passage of the Alaska National Interest Lands Conservation Act ("ANILCA"),22 Congress created a vast new conservation system in our northernmost state, including ten new national parks and three park expansions, consciously drawing the boundaries for these units to "follow hydrographic divides or embrace other topographic or natural features"-reflecting what might be described as an emerging congressional sensitivity to ecological conservation. ${ }^{23}$

A similar evolution has occurred in the Park Service's resource management policies. Throughout its early years, the national park system was largely built upon scenic wonders_dubbed "monumentalism" by a leading park historian-and these protected areas were managed primarily to ensure their scenic integrity_labeled "façade management" by one of the Park Service's own historians. ${ }^{24}$ Because any mention of science was notably missing from the 1916 Organic Act, scientific concerns played little role in the Agency's early management policies or practices, and its wildlife conservation efforts were mainly directed toward protecting "good" animals for the visiting public to see. ${ }^{25}$

20. See Runte, supra note 14, at 224-29; Robert B. Keiter, The National Park System: Visions for Tomorrow, 50 Nat. Resources J. 71, 77-78 (2010). Furthermore, in 1933, President Franklin Roosevelt ordered that sixty-four national monuments, military parks, and cemeteries be transferred from the Department of Defense and other agencies to the National Park Service for future management, thus further expanding and diversifying the national park system. RunTE, supra note 14, at 219-20. On the national heritage area concept, see generally Alan W. Barton, From Parks to Partnerships: National Heritage Areas and the Path to Collaborative Participation in the National Park Service's First 100 Years, 56 NAT. Resources J. 23 (2016).

21. See 16 U.S.C. $\$ 410 \mathrm{r}-7$ (2012); RunTE, supra note 5, at 101.

22. 16 U.S.C. $\S \S 3101-3233$ (2012); see generally Deborah Williams, ANILCA: A Different Legal Framework for Managing the Extraordinary National Park Units of the Last Frontier, 74 Denv. U. L. Rev. 859 (1997).

23. See ANILCA, Pub. L. No. 96-487, §§ 201-202, 94 Stat. 2377, 2382 (1980) (codified at 16 U.S.C. $\S \S 410 \mathrm{hh}-410 \mathrm{hh}-1$ ) (establishing the Aniakchak National Monument, Bering Land Bridge National Preserve, Cape Krusenstern National Monument, Gates of the Arctic National Park, Kenai Fjords National Park, Kobuk Valley National Park, Lake Clark National Park, Noatak National Preserve, Wrangell-Saint Elias National Park, and Yukon-Charley Rivers National Preserve, and expanding Glacier Bay National Monument, Katmai National Monument, and Mount McKinley National Park); see also infra note 196 and accompanying text (describing Congressional intent in ANILCA to "preserve . . . ecosystems").

24. See RunTe, supra note 14, at 29 ("monumentalism”); Sellars, supra note 5, at 4-5 ("façade management").

25. See Sellars, supra note 5, at 24; see also Robert B. Keiter, Preserving Nature in the National Parks: Law, Policy, and Science in a Dynamic Environment, 74 Denv. U. L. Rev. 649, 650, 667 (1997). 
Following publication of the seminal Leopold Report in 1963, ${ }^{26}$ the Park Service fundamentally altered its resource management policies, moving away from aesthetic preservation to begin employing science in order to maintain the parks in essentially their natural state, as a "vignette of primitive America." ${ }^{27}$ By then, it was also evident that the parks did not exist in a vacuum; they faced mounting threats in the form of energy projects, subdivision development, and timber harvesting that emanated from beyond their boundaries to threaten the ecological integrity of these special places. ${ }^{28}$ In fact, many parks had seen species go extinct during the past century owing to boundary shortcomings. ${ }^{29}$ Congress finally responded in 1998 by passing the National Parks Omnibus Management Act, ${ }^{30}$ which instructed the Park Service to employ science in managing the national parks, including studies on park units and their larger regions. ${ }^{31}$

Today, the national park system totals 417 units that extend across every state and cover more than 84 million acres. Although the system includes an array of designations and many relatively small historical sites and battlefields, the large natural park units provide critical habitat for diverse species and preserve important ecosystems. The Park Service has become ever more sensitive about building new roads or visitor facilities in the parks; for most new parks, these facilities are located outside the boundary in order to minimize disturbances within the park itself. ${ }^{32}$ In several cases, Congress has overlaid national park lands with a wilderness designation, thus legally prohibiting any construction activity on these lands. ${ }^{33}$ Under its all-important Management Policies, the Park Service is committed to managing park lands and resources "to preserve fundamental physical and biological processes, as well as individual species, features, and plant and animal communities," recognizing that "park units must be

26. See A.S. Leopold et al., Wildlife Management in the National Parks, reprinted in America's National Park System: The Critical Documents 237-51 (Lary M. Dilsaver ed., 1994).

27. Id. at 239; see Sellars, supra note 5, at 214-17.

28. Nat'l Park Serv., State of the Parks, 1980: A Report to Congress, partially reprinted in America's National Park System: The Critical Documents, supra note 26, at 405; Robert B. Keiter, On Protecting the National Parks from the External Threats Dilemma, 20 Land \& Water L. Rev. 355, 358-69 (1985); Robert B. Keiter, To ConServe Unimpaired: The Evolution of the National Park Idea 204-13 (2013).

29. See William D. Newmark, Extinction of Mammal Populations in Western North American National Parks, 9 Conservation Biology 512 (1995); see also William D. Newmark, Legal and Biotic Boundaries of Western North American National Parks: A Problem of Congruence, 33 Biological Conservation 197 (1985).

30. National Parks Omnibus Management Act of 1998, Pub. L. No. 105-391, 112 Stat. 3497 (1998) (codified at 16 U.S.C. $\S \S 5931-5937$ (2012)).

31. 16 U.S.C. $\S \S 100702,100703,100706$ (2012).

32. See Paul Sutter, Driven Wild 245-48 (2002); John C. Miles, Wilderness in National Parks: Playground or Preserve? 48 (2009).

33. See Miles, supra note 32, at 270-71, 277; Runte, supra note 14, at 240-43. 
managed in the context of their larger ecosystems." ${ }^{34}$ Several national parks serve as a vital refuge for wildlife species, like the grizzly bear that has slowly rebounded in Yellowstone and Glacier national parks from near extinction and extended its range onto the surrounding lands. ${ }^{35}$ Particularly in the West, park units are often situated adjacent to national forests or other public lands, creating the opportunity to knit these lands together for conservation purposes, which is already occurring in several locations under the "greater ecosystem" rubric and similar appellations. ${ }^{36}$ In short, the national parks regularly serve as the vital core of larger ecosystems, making them a critical part of most wildlife or ecosystem conservation efforts. ${ }^{37}$

\section{B. The National Wildlife Refuge System}

The National Wildlife Refuge System, much like the national park system, has evolved haphazardly over time. Its origins date to 1903, when President Theodore Roosevelt summarily issued a proclamation reserving Pelican Island as a "preserve and breeding ground for native birds." 38 Since then, through presidential and legislative designations on public lands as well as fee simple and easement acquisitions on private lands, the system has expanded to include a "crazy quilt" mixture of wildlife refuges, migratory bird refuges, waterfowl production areas, game ranges, wildlife management areas, and other units. ${ }^{39}$ In 1966, Congress adopted the National Wildlife Refuge System Administration Act and consolidated these diverse units into a single national wildlife refuge system dedicated to animal conservation. ${ }^{40}$ During the early years, several laws helped to build the system, including the Migratory Bird Treaty Act of 1918, ${ }^{41}$ which imposed federal hunting limits on birds, and the

34. Nat'l Park Serv., Management Policies 36 (2006), https://perma.cc/8S55-JJAY [hereinafter NPS Management Policies].

35. See Sellars, supra note 5, at 253; see also Craig L. Shafer, Land Use Planning: A Potential Force for Retaining Habitat Connectivity in the Greater Yellowstone Ecosystem and Beyond, 3 Global Ecology \& Conservation 256, 259-60 (2015).

36. See The Greater Yellowstone Ecosystem: Redefining America's Wilderness Heritage 65-73 (Robert B. Keiter \& Mark S. Boyce eds., 1991); Susan Clark, Ensuring Greater Yellowstone's Future 13-15, 30-33 (2008); Joseph L. Sax \& Robert B. Keiter, The Realities of Regional Resource Management: Glacier National Park and Its Neighbors Revisited, 33 Ecology L.Q. 233, 300-05 (2006); Dena Pedynowski, Prospects for Ecosystem Management in the Crown of the Continent Ecosystem, Canada-United States: Survey and Recommendations, 17 Conservation Biology 1261, 1261-62 (2003); Keiter, To ConSERVE UNIMPAIRED, supra note 28 , at 203-30.

37. See Keiter, To Conserve Unimpaired, supra note 28, at 203-30.

38. Exec. Order No. 1014 (1903).

39. Fischman, supra note 6, at 23-31.

40. Pub. L. No. 89-669, 80 Stat. 926 (1966) (codified at 16 U.S.C. §§ 668dd-668ee (2012)); 16 U.S.C. $\S 668 \mathrm{dd}(\mathrm{a})(1)$ (2012) (consolidating the system).

41. 16 U.S.C. §§ 703-712 (2012). 
Migratory Bird Hunting Stamp Act of $1934,{ }^{42}$ which required hunters to purchase a federal duck stamp to generate revenue to acquire waterfowl conservation areas. In 1940, President Franklin Roosevelt issued an executive order creating the U.S. Fish and Wildlife Service ("FWS") to administer the growing system of refuges and waterfowl conservation areas. ${ }^{43}$ With passage in 1980 of the ANILCA, ${ }^{44}$ Congress tripled the size of the refuge system by adding several large new ecosystem-defined units, including the 19.6-million-acre Arctic National Wildlife Refuge, which accommodates the Porcupine Caribou herd on its annual 1000 -mile migratory journey. ${ }^{45}$

Today, the refuge system numbers more than 550 units that encompass more than 95 million acres spread across all fifty states. ${ }^{46}$ It includes several strategic bird refuges located along the major north-south migratory waterfowl flyways, an obvious commitment to landscape-scale conservation. Many of the refuges are situated in low-lying coastal areas, protecting ecosystem types not well represented in the more mountain-focused national park system. Approximately 20 million acres in the refuge system are overlaid with a wilderness designation, and 1400 miles of designated wild and scenic rivers are part of the system. Refuge visitation has grown to over 45 million annually, ${ }^{47}$ a figure that pales in comparison to national park visitation numbers. However, many refuges are located near major urban areas, making them readily accessible to the nation's growing urban populace. ${ }^{48}$

42. 16 U.S.C. $§ \S 718-718(\mathrm{~h})$ (2012) (commonly known as the Duck Stamp Act).

43. The Reorganization Plan No. 3, 54 Stat. 1232 (1940); see also the Reorganization Act of 1939, Pub. L. No. 76-19, ch. 36, 53 Stat. 561 (1939) (granting the President governmental reorganization authority).

44. 16 U.S.C. §§ 3101-3233 (2012).

45. See Pub. L. No. 96-487, § 303(2), 94 Stat. 2371, 2390 (1980) (adding the Arctic NWR); Karsten Heuer, Being Caribou 14-15, 24 (2008).

46. Robert L. Fischman, The Significance of National Wildife Refuges in the Development of U.S. Conservation Policy, 21 J. LANd Use \& EnvTl. L. 1, 3-4 (2005). These figures do not include the recent massive marine national monuments added to the system. The Marine National Monuments were established through the January 2009 Presidential Proclamations that designated the Marianas Trench, Pacific Remote Islands, and Rose Atoll as three $\mathrm{Pa}$ cific Marine National Monuments. The Marine National Monument Program also manages the Papahanaumokuakea Marine National Monument, which was created in 2006. In 2014, the Obama Administration announced the expansion of the Pacific Remote Islands Marine National Monument to nearly 490,000 square miles. See Marine National Monument Program, NAT'L OcEANIC AND Atmospheric Admin., https://perma.cc/NR64-4UBK; Brian Clark Howard, U.S. Creates Largest Protected Area in the World, $3 X$ Larger Than California, NAT'L GeOgRAPHic (Sept. 26, 2014), https://perma.cc/FT7S-ETZR.

47. U.S. Fish \& Wildlife Serv., Refuges Earn High Marks with Visitors, https://per ma.cc/B8ZX-8K6Q (citing figures in 2011).

48. For a detailed description of the modern national wildlife refuge system, see FISCHMAN, supra note 6 , at $15-31$. 
Early on, management priorities and practices on the refuges were not well defined, creating conflicts between wildlife preservation, hunting, and other recreational pressures. In 1962, faced with increased visitation, Congress passed the Refuge Recreation Act, which permitted public recreation use in a refuge "only to the extent that is practicable and not inconsistent with ... the primary objectives for which each particular area is established," thus establishing a "compatibility" standard for determining the uses allowed on the refuges. ${ }^{49}$ As the twentieth century wound down, however, many refuges faced mounting internal recreational use pressures as well as external development threats that were wreaking noticeable environmental harm, threatening the very wildlife that these units were intended to protect. ${ }^{50}$ Congress eventually responded by adopting the National Wildlife Refuge System Improvement Act of 1997, which has launched the FWS on a new science-oriented refuge management program..$^{51}$ Incorporating contemporary ecological concepts and related management approaches, the 1997 legislation gave the FWS a clear-cut—or dominant-conservation mission, ${ }^{52}$ prioritized wildlife-dependent recreation among permitted uses, mandated comprehensive conservation planning, and established a progressive "biological integrity, diversity, and environmental health" management standard. ${ }^{53}$ Under these new statutory provisions, the Agency gives wildlife conservation top priority on the refuges and is pursuing ecosystem-based management policies that transcend refuge boundaries.

\section{The National Wilderness Preservation System}

A relative newcomer, the National Wilderness Preservation System was established in 1964 with the passage of the Wilderness Act. ${ }^{54}$ The wilderness label, however, emerged much earlier as an administrative designation to pro-

49. Refuge Recreation Act of 1962, Pub. L. No. 87-714, 76 Stat. 653 (codified at 16 U.S.C. $\S 460 \mathrm{k}(2012))$. Four years later, when Congress consolidated the refuges into a single system, it modestly broadened the 1962 "compatibility" management standard. See 16 U.S.C. $\S \S 668 \mathrm{dd}(\mathrm{d})(1), 668 \mathrm{ee}(1)-(2)$ (2012) (using the term "compatibility" for the first time and establishing a higher standard for approving some uses and easements across the refuge system).

50. See Fischman, supra note 6, at 56-63.

51. Pub. L. No. 105-57, 111 Stat. 1252 (codified at 16 U.S.C. §§ 668dd, 668ee (2012)); see also Robert L. Fischman, The National Wildlife Refuge System and the Hallmarks of Modern Organic Legislation, 29 EcOLOGY L.Q. 457, 514-92 (2002) (describing and analyzing the 1997 legislation).

52. See 16 U.S.C. $§ 668 \mathrm{dd}(\mathrm{a})(2), 4(\mathrm{~A})-(\mathrm{C})$ (2012). However, the purpose statement for individual refuges will override this organic legislation in the event of conflict between the two. See id. $\S 668 \mathrm{dd}(\mathrm{a})(4)(\mathrm{D})$.

53. Id. $\S 668 \mathrm{dd}(\mathrm{a})(4)(\mathrm{B})$. For a comprehensive discussion of the "biological integrity, diversity, and environmental health" standard in the 1997 Refuge System Improvement Act, see the symposium articles found in 44 Nat. Resources J. 931, 939-1238 (2004).

54. Pub. L. No. 88-577, 78 Stat. 890 (codified at 16 U.S.C. $§ 1131-1136$ (2012)). 
tect select national forest lands from development. During the 1920s, while serving as a young forest ranger, Aldo Leopold convinced the fledgling Forest Service to set aside the Gila Wilderness Area in southern New Mexico, arguing that some natural areas should be spared from development for recreational, spiritual, and health reasons. ${ }^{55}$ As the idea took hold within the Agency, other remote areas were soon protected as "primitive areas," and nationwide rules were promulgated to govern their management. ${ }^{56}$ But as development pressures in the form of dam and road construction proposals as well as timber and mining activities mounted, it became apparent to wilderness advocates that stronger legal protection was necessary to safeguard the rapidly growing nation's remaining wild places on the public lands. Even the national parks were not immune from such development pressures; committed to attracting automobile travelers to the growing system, the Park Service was busy constructing roads, lodges, and other facilities, making it apparent that the national parks could not be counted on to protect the nation's wilderness heritage. ${ }^{57}$ During the 1950 s, following a landmark victory at Echo Park where conservation groups succeeded in blocking construction of a new dam inside the Dinosaur National Monument, ${ }^{58}$ wilderness proponents decided to seek new legislation that would permanently protect the remaining undisturbed public lands.

After a decade-long campaign, Congress finally passed the Wilderness Act in 1964, not only giving legal meaning to the term "wilderness," but also permanently protecting 9.1 million acres of national forest lands (formerly "wilderness," "wild," or "canoe" areas) as official wilderness. ${ }^{59}$ According to the Act, "wilderness" is "an area where the earth and its community of life are untrammeled by man ... an area of Federal land retaining its primeval character and influence, without permanent improvements or human habitation, which is protected and managed so as to preserve its natural conditions." ${ }^{60} \mathrm{~A}$ wilderness area designation serves as an overlaying legal mandate, altering the land management standard but leaving management responsibility for the lands with the agency otherwise responsible for them. ${ }^{61}$ Development activities such as $\log$ ging, mining, water projects, and new roads are generally prohibited in desig-

55. Doug Scott, The Enduring Wilderness 27-30 (2004).

56. See Samuel Trask Dana \& Sally K. Fairfax, Forest and Range Policy 132-34, 157-58, 218-19 (2d ed. 1980); SCOTT, supra note 55, at 29.

57. See Keiter, To Conserve Unimpaired, supra note 28, at 18-21.

58. See Harvey, supra note 11 , at 284-85.

59. 16 U.S.C. $\S \S 1131$ (c), 1132(a) (2012); ScOTT, supra note 55, at 57 (designating 9.1 million acres of statutory wilderness areas).

60. 16 U.S.C. $§ 1131$ (c) (2012); see also id. § 1131(a) (providing that “"wilderness areas' . . shall be administered for the use and enjoyment of the American people in such manner as will leave them unimpaired for future use and enjoyment as wilderness, and so as to provide for the protection of these areas, the preservation of their wilderness character, and the gathering and dissemination of information regarding their use and enjoyment as wilderness ...").

61. See id. § 1133 . 
nated wilderness areas, as are lodges, motors, and commercial activities-these latter prohibitions clearly distinguishing wilderness areas from national parks. ${ }^{62}$ Congress retained for itself the power to designate new wilderness areas, ${ }^{63}$ making wilderness protection an exercise in political power and spurring a grassroots conservation movement to promote additional wilderness designations. ${ }^{64}$ Although the Wilderness Act only covered national forest, park, and wildlife refuge lands, the 1976 Federal Land Policy and Management Act ("FLPMA") soon added wilderness to the Bureau of Land Management's ("BLM's") portfolio, ${ }^{65}$ giving all four federal land management agencies similar wilderness review and stewardship responsibilities.

Under the Wilderness Act and FLPMA, the agencies were responsible for inventorying their roadless lands for possible wilderness designation and then recommending potential areas for protection. This review process provoked extended and often hotly contested wilderness designation battles across the nation, culminating in the passage of several key pieces of wilderness legislation: the Eastern Wilderness Areas Act of 1975; ${ }^{66}$ the Endangered American Wilderness Act of 1978; ${ }^{67}$ the ANILCA of 1980; ${ }^{68}$ twenty separate state wilderness bills in 1984;69 the Arizona Desert Wilderness Act of 1990; ${ }^{70}$ and the California Desert Protection Act of $1994 .^{71}$ Since then, most new wilderness bills have been adopted piecemeal, the result of locally negotiated agreements to protect relatively modest acreage, sometimes with notable non-wilderness provisions attached to the bill. ${ }^{72}$ The Steens Mountain Cooperative Management and Protection Act of 2000, for example, designated new wilderness areas while also establishing a new cooperative management and protection area, creating a twelve-person advisory council and a separate science committee, providing for specific land exchanges, and addressing juniper management in some detail. ${ }^{73}$ In short, as the obvious and less controversial areas have been added to the system, the politics of wilderness designation have become more challenging,

62. See id. These prohibitions are subject to several exceptions and grandfather provisions as specified in the statute.

63. Id. § 1132(b).

64. See, e.g., Harvey, supra note 11, at 210; John D. Leshy, Legal Wilderness: Its Past and Some Speculations on Its Future, 44 EnvTL. L. 549, 569 (2014).

65. See 43 U.S.C. $\$ 1782$ (2012); John D. Leshy, Wilderness and Its Discontents-Wilderness Review Comes to the Public Lands, 1981 ARIZ. ST. L.J. 361, 373 (1981).

66. Pub. L. No. 93-622, 88 Stat. 2096 (1975).

67. Pub. L. No. 95-237, 92 Stat. 40 (1978).

68. Pub. L. No. 96-487, 94 Stat. 2371 (1980).

69. See KeIter, supra note 10, at 201.

70. Pub. L. No. 101-628, 104 Stat. 4469 (1990).

71. Pub. L. No. 103-433, 108 Stat. 4471 (1994).

72. See John D. Leshy, Contemporary Politics of Wilderness Preservation, 25 J. LAND, Resources \& ENVTL. L. 1, 8-9 (2005).

73. 16 U.S.C. $\S \S 460 n n n-1-122$ (2012). 
the result being that the scope of wilderness bills has diminished from national to regional to statewide to local in focus.

The result, nonetheless, is an expansive national wilderness system that covers nearly 110 million acres of public land and extends across forty-four states. ${ }^{74}$ Although the early wilderness designations largely covered high elevation, "rock and ice" mountainous lands ${ }^{75}$ more recent designations have included lower-elevation BLM and national wildlife refuge lands, broadening the range of ecosystems within the system. In several locations, as in the Yellowstone and Glacier regions, designated wilderness lands abut large national parks and other protected lands, creating expansive wildland complexes with little permanent human presence. Over time, the underlying rationale for protecting these wilderness strongholds has evolved beyond recreation and spiritual renewal to encompass wildlife conservation and ecosystem preservation, reflecting contemporary scientific insights about the value of wildland areas in safeguarding species at risk and ecological processes. ${ }^{76}$ The successful grey wolf reintroduction effort in the Greater Yellowstone region and Idaho's Salmon-Selway wilderness complex exemplifies this transformation in our understanding of the role and value of wilderness lands for sustaining our biological heritage. ${ }^{77}$ And this role will become even more important as the natural world seeks to adapt to the warming temperatures sparked by climate change.

\section{National Landscape Conservation System}

Among the federal land management agencies, the BLM is a relative latecomer to preservation. Long known as a resource development agency, the BLM administers mostly arid lands in the western United States that the settlers passed over and that were not thought to have significant conservation value. First created in 1946 by merging the General Land Office and the Grazing Services, the BLM initially lacked a clear congressional mandate and mostly focused on managing mineral, range, and other commodity resources. ${ }^{78}$ In 1970, however, Congress established the King Range National Conservation Area along the northern California coast, directing the BLM to manage these

74. See Wilderness Act, The Wilderness Soc'y, https://perma.cc/A8RE-MPNQ.

75. Dave Foreman, The Wildlands Project and the Rewilding of North America, 76 Denv. U. L. Rev. 535, 545 (1999).

76. See Keiter, supra note 10, at 186-92; Michael Frome, Battle for the Wilderness xxx to xxxvii (rev. ed., 1997); Dave Foreman, Wilderness: From Scenery to Nature, in The Great New Wilderness Debate, supra note 7, at 568-84.

77. See Thomas McNamee, The Return of the Wolf to Yellowstone 315-23 (1997); Douglas W. Smith \& Gary Ferguson, Decade of the Wolf 169-94 (2006).

78. See James R. Skillen, The Nation's Largest Landlord 14-15 (2009). 
lands largely for their conservation values. ${ }^{79}$ In 1976, Congress finally invested the BLM with an organic statute, FLPMA, ${ }^{80}$ which contained a broad multiple-use mandate and imposed, for the first time, wilderness review and management responsibilities on the agency. ${ }^{81}$ These conservation and wildernessrelated responsibilities broke new ground for an agency renowned for its commitment to commodity production, creating an opportunity for the BLM to embark on a complementary preservation effort.

The new FLPMA-mandated wilderness review process ignited controversy across much of the West. Wilderness advocates pressed the BLM to identify expansive potential wilderness areas while opponents decried the effort as a federal lock-up of productive lands and resources. Despite this emerging controversy, Congress passed separate Arizona and California BLM wilderness bills during the early 1990s, protecting nearly six million acres. Meanwhile, through its wilderness review process, the BLM designated 919 wilderness study areas covering 24 million acres that not only qualified for congressional designation as wilderness, ${ }^{82}$ but also enjoyed substantial legal protection under the relevant FLPMA provision until Congress acted on the wilderness recommendation. ${ }^{83}$ In 1996, President Clinton exercised his power under the Antiquities Act to establish a 1.7 million-acre Grand Staircase-Escalante National Monument in southern Utah on BLM lands and, for the first time, vested the BLM with responsibility for managing a national monument. ${ }^{84}$ By the time he left office in 2001, President Clinton had proclaimed another thirteen BLMmanaged national monuments in seven different states, protecting more than 2.3 million acres from development. ${ }^{85}$ In several instances, such as the one-

79. Pub. L. No. 91-476, 84 Stat. 1067 (1970) (codified as amended at 16 U.S.C. §§ 460y3-460y-9 (2012)).

80. 43 U.S.C. $\S \S 1701-1784$ (2012).

81. Id. § 1732(a) ("multiple use" mandate); id. § 1702(c) (defining "multiple use"); § 1782 (wilderness review).

82. George C. Coggins et al., Federal Public Land and Resources Law 968 (7th ed., 2014); SKILLEN, supra note 78, at 123.

83. Under FLPMA, once the BLM completed its state-wide wilderness inventory review, those areas selected as "wilderness study areas" received enhanced legal protection, bestowing them with a protective status nearly akin to a formal "wilderness" designation, at least until Congress resolved the wilderness issue in that state. 43 U.S.C. § 1782(c); see Utah v. Andrus, 486 F.Supp. 995 (D. Utah 1979); Rocky Mountain Oil and Gas Ass'n v. Watt, 696 F.2d 734 (10th Cir. 1982).

84. Proclamation No. 6920, 61 Fed. Reg. 50,223 (1996); see John D. Leshy, The Babbitt Legacy at the Department of the Interior: A Preliminary View, 31 EnVTL. L. 199, 216-17 (2001). In December 2017, President Trump reduced the size of the monument to roughly one million acres. Presidential Proclamation 9682, Modifying the Grand Staircase-Escalante National Monument, 82 Fed. Reg. 58,089 (Dec. 4, 2017).

85. See The Antieuities Act, supra note 15, at 295-97; see also Leshy, supra note 84, at 216-21 (describing the rationale for President Clinton's BLM-managed national monument designations). 
million-acre Grand Canyon-Parashant National Monument, ${ }^{86}$ the protected lands adjoined national parks, effectively expanding the federal protective commitment in that landscape. Seeking to legitimize preservation as an important part of the BLM's resource management responsibilities and to thus reform the agency's development-oriented culture, Secretary of the Interior Bruce Babbitt administratively consolidated the BLM's diverse and growing conservation landholdings into a so-called "National Landscape Conservation System" ("NLCS"). ${ }^{87}$

In 2009, Congress endorsed Babbitt's idea by passing a National Landscape Conservation System Act that formally incorporated all of the BLM's protected lands into a single new system. ${ }^{88}$ By law, the BLM was directed "to conserve, protect, and restore nationally significant landscapes that have outstanding cultural, ecological, and scientific values for the benefit of current and future generations." ${ }^{89}$ Embraced within the NLCS are roughly 36 million acres of BLM-managed lands, including 27 national monuments, 21 national conservation areas or similar designations, 224 wilderness areas, 517 wilderness study areas, 69 wild and scenic rivers, and 18 national scenic or historic trails. ${ }^{90}$ Most of these lands are located in the western United States, with a few areas in Alaska. Although preservation is the dominant management goal in these areas, many of them are governed by enabling statutes or monument proclamations that grandfather preexisting uses, allow some incompatible activities to occur, and provide for local advisory committees to participate in management and planning decisions. ${ }^{91}$ Because several of the presidentially-decreed national monuments have been controversial from the outset, Congress has been reluctant to fully fund this new NLCS, hampering the BLM's planning and man-

86. Proclamation No. 7265, 65 Fed. Reg. 2825 (2000). Under the proclamation, the monument is jointly managed by the BLM and the National Park Service. Id. Other Clinton-era national monuments adjoining national parks are the Giant Sequoia National Monument in southern California (adjacent to Sequoia-Kings Canyon National Park) and Vermillion Cliffs National Monument in northern Arizona (adjacent to Grand Canyon National Park). Keiter, The National Park System, supra note 20, at 101.

87. SKILLEN, supra note 78, at 155-56.

88. 16 U.S.C. $\S \S 7201-7203$ (2012).

89. Id. $\S 7202(\mathrm{a})$.

90. About NCL, National Conservation Lands Summary Table, Bureau of Land Mgmt., https://perma.cc/C924-3AEK (including the Bears Ears and Gold Butte national monuments that were added to the system by President Obama in December 2016). But see infra note 144 (explaining that President Trump has reduced the size of the Bears Ears National Monument by roughly 1.15 million acres); infra note 334 (explaining that President Trump has reduced the size of the Grand Staircase-Escalante National Monument by roughly 0.9 million acres).

91. See, e.g., Dominguez-Escalante National Conservation Area, 16 U.S.C. § 460zzz (2012); Owyhee Public Land Management, Pub. L. No. 111-11, tit. I, §1501-1508, 123 Stat. 1032-1044 (2009); Proclamation No. 7295, Sequoia National Monument, 65 Fed. Reg. 24,095 (Apr. 15, 2000). 
agement efforts. ${ }^{92}$ Nonetheless, the BLM has prioritized resource protection on its NLCS lands and committed to landscape-scale planning that includes addressing wildlife corridors, habitat connectivity, and climate change impacts. ${ }^{93}$ With millions of acres still eligible for official wilderness designation or, alternatively, protection as a national monument, this newest system of protected BLM lands is likely to grow in size in the coming years.

\section{E. National Forest Roadless Areas}

Once Congress passed the 1964 Wilderness Act and defined "wilderness" eligibility in terms of the land's roadless character, the Forest Service's management of roadless areas became the central focus of the national forest wilderness debate. Twice during the 1970s, the Forest Service undertook a nationwide review of its roadless lands, dubbed RARE ONE and RARE TWO, seeking to determine which of these lands merited wilderness protection. ${ }^{94}$ In each instance, conservation groups were deeply disappointed by the Forest Service's paltry wilderness acreage recommendation and successfully enjoined the agency's final decision, forcing it to broaden its approach to wilderness eligibility. ${ }^{95}$ In 1984, Congress broke this stalemate by passing twenty state-wide national forest wilderness bills, effectively resolving the wilderness issue for the immediate future for most western states, though neither Idaho nor Montana were included in this legislative whirlwind. ${ }^{96}$ The undesignated national forest roadless lands covered by these bills were "released" from further wilderness consideration to be managed under the Forest Service's "multiple use" mandate through its planning process. ${ }^{97}$

Wilderness advocates, however, still sought to protect these remaining roadless lands-roughly 60 million acres across the national forest systemfrom development, hoping to eventually secure permanent wilderness protection for them. With few exceptions, whenever the Forest Service proposed a timber sale, mining project, or other development activity on its remaining roadless lands, conservation groups not only protested but filed legal actions seeking to halt the proposed industrial use. ${ }^{98}$ Occasionally, Congress would get

92. See Report: National Conservation Lands Chronically Underfunded, The WiLderness Soc'y, https://perma.cc/Q3F6-BGY3.

93. See Bureau of Land Mgmt., The National Landscape Conservation System: 15 Year Strategy, 2012-2014 (2011); Sec'y of the Interior, Order No. 3308, Management of the National Landscape Conservation System (Nov. 15, 2010).

94. Sсотт, supra note 55 , at $80-83$.

95. California v. Block, 690 F.2d 753 (9th Cir. 1982); see also Allin, supra note 7, at 164 (describing the Forest Service's RARE process).

96. See KeIter, supra note 10, at 201-03.

97. John C. Hendee et al., Wilderness Management 141-42 (2d ed., 1990).

98. See, e.g., Martin Nie, Administrative Rulemaking and Public Lands Conflict: The Forest Service's Roadless Rule, 44 NAt. Resources J. 687, 699 (2004). 
involved and establish a new wilderness area, ${ }^{99}$ or the courts would intervene to block the proposed activity. ${ }^{100}$ The result was a near-perpetual deadlock over management of roadless national forest lands.

During the Clinton Administration, the Forest Service issued a national roadless area conservation rule that prohibits new road construction and timber harvest on these forest lands. ${ }^{101}$ It was not the first time that the Agency used its administrative authority to protect its lands; it did something similar during the 1920s and 1930s when it administratively created new wilderness and primitive areas and issued rules designed to protect these areas from industrial activity. ${ }^{102}$ Finalized in early 2001, the agency's roadless area rule encompassed 58.5 million acres or roughly one third of the entire national forest land base. ${ }^{103}$ To support its new rule, the Forest Service explained that its roadless lands served as "biological strongholds for terrestrial and aquatic plants and wildlife and as sources of high-quality water," 104 and also harbored more than half the federally protected endangered species found in the national forests. Moreover, the Agency observed that "a growing number of people value Federal lands as a repository of biodiversity and conservation ... . [and] appreciate [these] lands more for their inherent naturalness than for the[ir] commodities, such as timber, minerals, and grazing." 105 The rule ultimately survived court attacks from western states that opposed this protective measure, as well as the Bush Administration's efforts to substantially revise it. ${ }^{106}$ As a result, nearly 60 million acres of national forest lands are today managed for their conservation and recreational values, augmenting the 35 million acres of national forest wilderness lands. In sum, the roadless area rule represents a substantial commitment to

99. Id. at 713 .

100. See, e.g., Smith v. U.S. Forest Serv., 33 F.3d 1072, 1079 (9th Cir. 1994) (noting that the U.S. Forest Service is obligated to take a "hard look" at the proposed sale and acknowledge the existence of the 5,000 acre roadless area); Nat'l Audubon Soc'y v. U.S. Forest Serv., 46 F.3d 1437 (9th Cir. 1993) (noting that issues regarding roadless areas are entitled to judicial review under the "arbitrary and capricious" standard).

101. See 36 C.F.R. § 294 (2016); Special Areas; Roadless Area Conservation, 66 Fed. Reg. 3244, 3272 (Jan. 12, 2001); U.S. Forest Serv., Forest Service Roadless Area Conservation Final Environmental Impact Statement (2000) [hereinafter U.S. Forest Service Roadless Area FEIS].

102. See supra note 56 and accompanying text.

103. Special Areas; Roadless Area Conservation, 66 Fed. Reg. 3244, 3245 (Jan. 12, 2001).

104. U.S. Forest Service Roadless Area FEIS, supra note 101, at 3-395.

105. Id. at 3-393.

106. See Jayne v. Sherman, 706 F.3d 994 (9th Cir. 2013); Wyoming v. U.S. Dep't of Agric., 661 F.3d 1209 (10th Cir. 2011), cert. denied, 568 U.S. 928 (2012); California ex rel. Lockyer v. U.S. Dep't of Agric., 575 F.3d 999 (9th Cir. 2009); Kootenai Tribe v. Veneman, 313 F.3d 1094 (9th Cir. 2002). 
nature preservation on the national forests, albeit one with less legal protection than legislatively designated wilderness areas. ${ }^{107}$

\section{F. Other Protected Lands: Federal, State, and Tribal Designations}

Federally protected lands extend beyond national parks, refuges, and wilderness areas to include other designations that safeguard important nature conservation values and could therefore be incorporated into landscape-level conservation efforts. These include wild and scenic river segments and national scenic trails, many of which traverse protected federal lands as well as other public lands managed for multiple-use purposes and privately owned lands. Department of Defense lands, although primarily devoted to military purposes, contain important biological resources and are often located adjacent to federal public lands, thus offering landscape-scale planning opportunities geared toward nature conservation. Moreover, the states and Native American tribes are also engaged in their own land preservation efforts in the form of state parks, wildlife reserves, and wilderness designations.

In 1968, Congress adopted the National Wild and Scenic Rivers Act, ${ }^{108}$ with the express purpose of preserving segments of the nation's rivers as freeflowing waterways and protecting "their immediate environments." 109 The system now encompasses 12,709 miles of 208 rivers in forty states, ${ }^{110}$ divided into wild, scenic, and recreational river components, ${ }^{111}$ which enjoy varying levels of

107. The courts, however, have extended legal protection to roadless national forest lands. See Lands Council v. Martin, 529 F.3d 1219, 1230-31 (9th Cir. 2008) (commenting that the Forest Service is obligated to consider 4284-acre roadless area's wilderness potential); Idaho Conservation League v. Guzman, 766 F.Supp.2d 2011 (D. Idaho 2011) (noting that the Forest Service's travel plan must evaluate the impact of off-road vehicle micro-routes on the roadless area's wilderness potential).

108. 16 U.S.C. $\S \S 1271-1287$ (2012). For more information on the National Wild and Scenic Rivers Act, see generally Sally K. Fairfax et al., Federalism and the Wild and Scenic Rivers Act: Now You See It, Now You Don't, 59 WAsh. L. Rev. 417 (1984); Peter M. K. Frost, Protecting and Enhancing Wild and Scenic Rivers in the West, 29 IdaHo L. Rev. 313 (1992-93).

109. 16 U.S.C. $\S 1271$ (2012). Under the Act, both Congress and the states are empowered to designate protected river segments. 16 U.S.C. § 1273(a) (2012).

110. About the WSR Act, NAT'L WiLd \& Scenic Rivers Sys., https://perma.cc/QQJ2-83V3.

111. 16 U.S.C. $§ 1273($ b) (2012). Wild rivers are "those rivers or sections of rivers that are free of impoundments and generally inaccessible except by trail, with watershed or shorelines essentially primitive and water unpolluted . . . represent[ing] vestiges of primitive America." Scenic rivers are free of impoundments and still largely primitive and undeveloped but accessible in places by roads. Recreational rivers are accessible by road with some development and some impoundment or diversion. Both "wild" and "scenic" rivers are of obvious conservation value due to their mostly undeveloped condition, while "recreational" rivers are of more limited conservation value. 
legal protection. ${ }^{112}$ The Act establishes a detailed process for acquiring lands adjacent to designated segments while also granting limited condemnation authority, ${ }^{113}$ all subject to various restrictive standards-including a 320 -acre average limitation per mile of river. The responsible managing agencies, after consulting with state and local officials, must prepare a comprehensive management plan "for the protection of the river values" that addresses "resource protection, development of lands and facilities, [and] user capacities. ..."114 Several courts, discerning protective standards in the Act, have blocked recreational activities, construction proposals, and livestock grazing within designated river corridors. ${ }^{115}$

In the arid West and elsewhere, river corridors provide critical riparian habitat for numerous species, supply important ecosystem services, and serve as connective passageways for wildlife. These corridors provide exceptional ecological value for nature conservation purposes, especially as warming temperatures prompt species movement. Recognizing these facts and the laws that already protect riparian areas, several scientists have jointly called for establishment of a Riparian Connectivity Network in order to promote landscape-scale conservation and ecological resilience in existing protected areas. ${ }^{116}$ Simply put, the nation's designated wild and scenic river corridors represent an important component in the nation's protected lands systems, one that already serves multiple nature conservation goals and one that can be knit into a larger landscapescale conservation network.

Enacted in 1968, the National Trails System Act ("NTSA") was designed to address the nation's "ever-increasing outdoor recreation needs" and "to promote the preservation of . . outdoor areas." 117 The NTSA establishes three

112. 16 U.S.C. $\S 1283($ a) (2012) (requiring the responsible secretary to take action to protect designated rivers consistent with the purposes of the Act, giving particular attention to "scheduled timber harvesting, road construction, and similar activities which might be contrary to purposes of this chapter."). Once a "wild" river segment is designated, for example, federally owned minerals within one-quarter mile of the river's banks are permanently withdrawn from development. 16 U.S.C. § 1280(a)(iii) (2012).

113. 16 U.S.C. $\S 1277$ (2012).

114. 16 U.S.C. $§ 1274(d)(1)(2012)$.

115. See, e.g., Friends of Yosemite Valley v. Kempthorne, 520 F.3d 1024 (9th Cir. 2008); Wilderness Watch v. U.S. Forest Serv., 143 F.Supp.2d 1186 (D. Mont. 2000); Sierra Club v. United States, 23 F.Supp.2d 1132 (N.D. Cal. 1998); Or. Nat. Desert Ass'n v. Green, 953 F.Supp. 1133 (D. Ore. 1997). But see Newton Cty. Wildlife Ass'n v. U.S. Forest Serv., 113 F.3d 110 (8th Cir. 1997).

116. Alexander K. Fremier et al., A Riparian Conservation Network for Ecological Resilience, 191 Biological Conservation 29, 30 (2015).

117. 16 U.S.C. $\S \S 1241-1251$ (2012). National Scenic Trails run continuously for at least 100 miles, id. §1242(b), and generally prohibit motorized travel, while National Historic Trails commemorate historic routes of travel. For both trails, the routes are established through acts of Congress. Id. § 1244(a). National Recreation Trails are located primarily near urban areas, id. § 1243(a)(1), and include existing regional and local trails that have been recog- 
types of trails, one of them being "national scenic trails," defined as "extended trails so located as to provide for maximum outdoor recreation potential and for the conservation and enjoyment of the nationally significant scenic, historic, natural or cultural qualities of the areas through which such trails may pass." 118 Today, the system encompasses eleven national scenic trails and nineteen national historic trails that extend nearly 54,000 miles in combined length, and more than 1200 national recreation trails. ${ }^{119}$ Under the NTSA, the secretaries of Interior and Agriculture can designate trail rights of way without any limitation on size and to acquire lands necessary to create a trail corridor. The Act authorizes voluntary land and easement purchases, while requiring federal officials to collaborate with state and local officials when acquiring and managing trail segments. ${ }^{120}$ It also grants the secretaries condemnation authority, limited to 125 acres per mile of trail, ${ }^{121}$ which equates to a corridor roughly 1000 feet in width, an area large enough to facilitate wildlife movement.

Under the NTSA, the managing agencies are given regulatory authority that arguably extends beyond the trail corridor and might be used to curtail potentially threatening activities on adjacent lands. ${ }^{122}$ This is a particular problem along the Appalachian Trail with rapid regional population growth and related development pressures along the route. Although this iconic trail's 2190 mile route is now a protected "green ribbon" encompassing 280,000 acres, trail advocates have joined with the National Park Service to launch an Appalachian Trail Landscape Conservation Initiative, seeking "to look at the entire A.T. landscape as one whole system rather than a long, thin, linear corridor divided by boundaries and jurisdictions." 123 Under this vision, the national trail system not only represents actual corridors running across federal and nonfederal land-

nized by either the Secretary of Agriculture or the Secretary of the Interior as well as other trails designated with the consent of state and local governments or private landowners. $I d$. $\S 1243(\mathrm{~b})$.

118. Id. $\S 1242(\mathrm{a})(2)$. The 1968 NTSA legislation officially designated the already well-established Appalachian Trail and Pacific Crest Trail as the nation's first scenic trails, $i d$. $\S 1241(\mathrm{~b})$, leaving it to Congress to designate additional extended trails. These two trails serve as models for how the federal agencies working with local trail proponents and governmental entities at all levels can establish and manage similar new long-distance trails.

119. Fed. Interagency Council on Trails, National Trails System Annual Report FOR FY 2013, at 3 (2014), https://perma.cc/2UED-FHZU.

120. 16 U.S.C. $\S 1246(\mathrm{e})$, (h) (2012). These collaboration provisions were designed, in part, to prompt the states to develop their own trails legislation and programs. John S. Davis, The National Trails System Act and the Use of Protective Federal Zoning, 10 Harv. EnVTL. L. Rev. 189, 208-10 (1986).

121. 16 U.S.C. $§ 1246(\mathrm{~g})(2012)$. Congress has only granted express condemnation authority for four out of thirty scenic and historic trails nationwide. Melissa K. Scanlan, Blueprint for the Great Lakes Trail, 4 Mich. J. Envtl. \& Admin. L. 61, 82 (2014).

122. 16 U.S.C. $§ 1246($ i) (2012); see Davis, supra note 120, at 201, 222-55.

123. Dennis Shaffer, Connecting Humans and Nature: The Appalachian Trail Landscape Conservation Initiative, 33 George Wright F. 2, 175, 175, 179 (2016). 
scapes, but it also offers a model for how federal and nonfederal lands can be connected together for nature conservation purposes, especially for wildlife corridor protection purposes. ${ }^{124}$

Beyond the public lands, the Department of Defense's military bases are often quite expansive with significant fish and wildlife resources, including important habitats. In 1960, recognizing these realities, Congress adopted the Sikes Act, ${ }^{125}$ which requires the Department of Defense "to provide for the conservation and rehabilitation of natural resources on military reservations" by preparing, in cooperation with the FWS and state wildlife agencies, an Integrated Natural Resource Management Plan ("INRMP") for each installation. ${ }^{126}$ At least 325 military installations contain significant enough natural resources to be governed by INRMPs that cover roughly 28 million acres and address more than 420 federal endangered or threatened species-an indication of the biological importance of this acreage. ${ }^{127}$ The White Sands Missile Range in southern New Mexico, for example, embraces more than 2 million acres and sits among public lands overseen by all four federal land management agencies, a fact reflected in the Range's ecosystem-based resource management plan. ${ }^{128}$ Although maintaining military preparedness is the first obligation on these base lands, the INRMPs must provide for fish and wildlife management, habitat enhancement, wetland protection, and outdoor recreational opportunities. ${ }^{129}$ Under a 2013 multi-party agreement on cooperative management, ${ }^{130}$ military

124. See infra notes $400-406$ and accompanying text proposing a new federal wildlife corridor designation.

125. 16 U.S.C. $§ \S 670 \mathrm{a}-\mathrm{o}$ (2012); see Teresa K. Hollingsworth, The Sikes Act Improvement Act of 1997: Examining the Changes for the Department of Defense, 46 A.F.L. REv. 109 (1999); Gina Guy, Swords, not Plowshares: The Department of Defense as a Federal Land Manager, Wyo. L. 20, 22-23 (2003).

126. 16 U.S.C. $\S 670 a(a)(2012)$.

127. See Dep't of Def., Fifty Years of the Sikes Act (2012), https://perma.cc/4BKALF4P. In fact, Department of Defense lands contain the most federally listed species of any agency, even though these lands only represent 3\% of federally owned land in the U.S. See Craig R. Groves et al., Owning Up to Our Responsibilities: Who Owns Lands Important for Biodiversity, in Precious Heritage 275, 278-83 (Bruce A. Stein et al. eds., 2000). Moreover, although the Department of Defense lands cover approximately 14.4 million acres in the United States, the Department's INRMPs extend across more than 28 million acres, reflecting the collaborative, ecosystem-based management approach to these plans. CAROL Vincent et al., Cong. Research Serv., Federal Land Ownership: Overview and Data (2014); Dep't of Def., Fifty Years of the Sikes Act, supra, at 3.

128. Dep't of Def., White Sands Missile Range Integrated Natural Resource Management Plan 192, 262 (2001).

129. 16 U.S.C. $§ 670 \mathrm{a}(\mathrm{b})(2012)$. The INRMPs must be prepared and management decisions must be made consistent with existing federal laws, including the Endangered Species Act. Id. $\S 670 \mathrm{a}(\mathrm{a})(4)$.

130. Dep't of Def. et al., Memorandum of Understanding between the U.S. Department of Defense and the U.S. Fish and Wildlife Service and the Association of Fish and Wildlife Agen- 
officials will seek to incorporate "ecosystem management principles" when preparing INRMPs and reviewing specific projects, including when bases are proximate to National Wildlife Refuges or other federally managed lands. ${ }^{131}$ Moreover, several Department of Defense installations, including the former Rocky Flats Weapons Plant in Colorado, have been decommissioned in recent years and the lands converted to new national wildlife refuges. ${ }^{132}$ In short, while serving defense purposes, these military lands are also being managed to preserve important fish and wildlife values, adding another component to federal nature conservation efforts that might be linked to nearby federally protected lands.

The states have also established their own protected land systems, including state parks and wildlife reserves. Across the nation, more than 14 million acres are protected as state parks, but the size and level of protection individual state park units enjoy varies among the state systems. ${ }^{133}$ In the West, several large state parks are situated near federally protected lands, enhancing the overall conservation value of the area. In California, which boasts one of the largest state park systems at more than 1.6 million acres, the Anza-Borrego Desert State Park encompasses 585,000 acres that complement the complex of federally protected lands in the California desert. ${ }^{134}$ California's three Redwood state park units abut Redwood National Park, and the entire complex is managed cooperatively as a single unit along the state's northern coast. ${ }^{135}$ The state of Montana maintains more than fifty wildlife management areas, including the 19,700 acre Sun River area, which is situated adjacent to the Bob Marshall Wilderness Area along the eastern edge of the Rocky Mountains where it contains lower elevation habitat as part of the Crown of the Continent Ecosys-

cies for a Cooperative Integrated Natural Resource Management Program on Military Installations (2013), https://perma.cc/SHJ5-GEQ6.

131. U.S. Fish \& Wildlife Serv., Guidelines for Coordination on Integrated Natural Resources Management Plans (2015), https://perma.cc/NY5M-PYUT; see also Interagency Assistance Agreement between the U.S. Fish \& Wildlife Service and the United States Air Force for the Conservation of Natural Resources on Air Force Controlled Lands (2012) (agreeing to "cooperate in ways that will not only enhance the management of natural resources on Federal lands, but will facilitate landscape linkages contributing to regional biodiversity").

132. See David G. Havlick, Disarming Nature: Converting Military Lands to Wildlife Refuges, 101 Geographical Rev. 183, 194 (2011).

133. Margaret Walls, Res. for the Future, Parks and Recreation in the United States: State Park Systems (2009).

134. See infra notes 322-331 and accompanying text for a more detailed discussion of the California Desert area.

135. See Pieter M. O'Leary, A Walk in the Park: A Legal Overview of California's State and Federal Parks and the Laws Governing Their Use and Enjoyment, 52 NAT. Resources J. 237, 245 (2012). 
tem. ${ }^{136}$ Further, pursuant to the federal Wildlife Conservation and Restoration Program, the states have adopted comprehensive, science-based State Wildlife Action Plans that aim to conserve and restore important terrestrial and aquatic habitat. Developed in conjunction with the FWS and the Association of Fish and Wildlife Agencies, yet tailored to each state's unique geography, these State Wildlife Action Plans survey habitat conditions, outline specific conservation actions necessary to safeguard individual species, establish adaptive management protocols to measure progress, and provide for coordination with federal and other land management agencies. ${ }^{137}$ The Plans, in short, provide a roadmap to the strategies necessary to achieve measureable wildlife conservation and restoration goals across the larger landscape.

Native American reservations occupy large blocks of generally undeveloped and lightly populated land throughout the West. As sovereign nations, individual tribes oversee these reservation lands as well as the wildlife and other resources found on them. In some instances, tribes have imposed wilderness, roadless, or other protective designations on portions of their reservation lands, giving them substantial protection for nature conservation and cultural purposes. ${ }^{138}$ In northwestern Montana, for example, the Salish-Kootenai tribe acted in 1982 to establish the nation's first tribal wilderness area. ${ }^{139}$ At 92,000 acres, the Mission Mountains Tribal Wilderness Area abuts the federal Mission Mountains Wilderness area that, in turn, flanks the Bob Marshall Wilderness Area, creating an expansive protected area that stretches across several gamerich mountain ranges. ${ }^{140}$ In Wyoming, the Shoshone and Arapahoe tribes share the Wind River Indian Reservation and, since 1934, have managed the mountainous southwestern part of their reservation as the Wind River Roadless Area, thus adding more than 180,000 acres to the one million plus acres of federally designated wilderness that covers much of the Wind River Mountain Range. ${ }^{141}$ In California, local tribes have established the 4000-acre Intertribal Sinkyone

136. See Sun River, Mont. Fish, Wildlife \& PARKs, https://perma.cc/9RYY-YNEJ; see also Sun River Management Area, Mont. Office OF Tourism, https://perma.cc/858LCUWV.

137. 16 U.S.C. $§ 669 \mathrm{c}(\mathrm{e})(2012)$; see The Voice of Fish छ Wildlife Agencies, Ass'N OF FisH \& Wildlife Agencies, https://perma.cc/J4XE-PKZ5; Jeff Lerner et Al., Defs. of Wildlife, Conservation Across the Landscape: A Review of State Wildlife Action Plans (2006); Jessica B. Wilkinson \& Robert Bendick, The Next Generation of Mitigation: Advancing Conservation Through Landscape-Level Mitigation Planning, 40 Envtl. L. Rep. News \& Analysis 10,023, 10,025 (2010).

138. See Confederated Salish \& Kootenai Tribes, Mission Mountains Tribal WilDERness: A CASE Study (2005), https://perma.cc/B8KT-EJ2G.

139. Id.

140. Id. at $14-16$.

141. Don Aragon, The Wind River Indian Tribes, 13 InT'L J. Wilderness 14, 16 (2007). 
Wilderness along the state's northern coast and are managing the area for cultural and ecological purposes. ${ }^{142}$

The tribes are also becoming more engaged with resource management issues on nearby federal lands, asserting their sovereign status and treaty rights to safeguard sacred lands and cultural sites. Montana's Blackfeet tribe, for example, has secured establishment of a Traditional Cultural District in the Badger-Two Medicine area that lies adjacent to Glacier National Park and the Bob Marshall Wilderness Area, effectively blocking oil and gas development on these sensitive, ecologically important lands. ${ }^{143}$ Largely mirroring an unprecedented proposal by a coalition of five tribes, President Obama created the 1.35million-acre Bears Ears National Monument in southeastern Utah, which abuts Canyonlands National Park and Glen Canyon National Recreation Area, significantly expanding this protected landscape for both natural and cultural preservation purposes. ${ }^{144}$ As these tribal protective measures expand across Indian country, additional opportunities to join federal and tribal conservation efforts will almost certainly present themselves, given the deep Native American attachment to the natural world.

\section{G. Private Land Conservation: Land Trusts and Conservation Easements}

During the past several decades, private land conservation efforts have accelerated with little evidence that this trend will slow in the near future. Whether employing a fee simple purchase or conservation easement strategy, land trusts have acquired more than 56 million acres for nature conservation and open space preservation purposes. ${ }^{145}$ Organizations ranging from The $\mathrm{Na}$ ture Conservancy ("TNC"), with net assets of $\$ 6.7$ billion and an international presence, ${ }^{146}$ to the more modest Teton Regional Land Trust in eastern Idaho, ${ }^{147}$ have quietly been acquiring property rights on ranches, farms, and other private landholdings for the express purpose of preserving the area's natural values to enhance wildlife habitat, protect endangered species, provide outdoor recrea-

142. Hawk Rosales, The InterTribal Sinkyone Wilderness, 16 InTL. J. WiLderness 8 (2010).

143. Sax \& Keiter, supra note 36 , at 271-74.

144. Proclamation No. 9558, Establishment of the Bears Ears National Monument, 82 Fed. Reg. 1139 (Jan. 5, 2017). President Trump, however, has reduced the size of the monument to roughly 202,000 acres and created two small, separate noncontiguous units. Proclamation No. 9681, Modifying the Bears Ears National Monument, 82 Fed. Reg. 58081 (Dec. 4, 2017); see also infra note 369 and accompanying text. The Trump boundary modifications have been challenged in court. Associated Press, President Trump's National Monument Cuts Draw 5th Lawsuit, WAsh. Post (Dec. 7, 2017), https://perma.cc/TX6X-AL6V.

145. Land TR. All., supra note 3, at 3.

146. The Nature Conservancy, Our World: 2015 Annual Report 59, https://perma.cc/ $6 \mathrm{~N} 2 \mathrm{H}-\mathrm{KWG}$. The $\$ 6.7$ billion net asset figure includes conservation land, easements, and projects valued at $\$ 4$ billion dollars.

147. Teton Reg'L Land Tr., https://perma.cc/PSB7-C45K. 
tional opportunities, and safeguard vital water sources. Sometimes the land trust retains ownership and manages the acquired lands; other times it acts as an intermediary for a governmental entity, purchasing critical lands when they become available and then transferring them into public ownership when the necessary legislative appropriation is forthcoming. ${ }^{148}$

The land trust movement has experienced remarkable growth in the past decade. The number of active land trusts exceeds 1300 organizations, mostly operating at the state and local level, but also including thirteen national land trust organizations. ${ }^{149}$ California boasts the most land trusts at 136, with Massachusetts, Connecticut, New York, and Pennsylvania each having more than eighty such organizations. The northeastern region has just under 13 million acres conserved by land trusts, while the eleven western states have 24.4 million acres under conservation management. ${ }^{150}$ In the West, California land trusts have protected nearly five million acres, Colorado and Montana trusts oversee more than 3 million protected acres, while Arizona, New Mexico, and Nevada come in with more than 2.5 million acres in conservation status. ${ }^{151}$ This growth in the land trust movement can be attributed to several factors, including favorable federal and state tax policies providing meaningful financial incentives to conservation-minded sellers, an evident conservation ethic among many landowners, and legal changes facilitating the creation of conservation easements. ${ }^{152}$

Although the motives underlying conservation purchases vary, many land trusts focus on preserving wildlife habitat and ecological values. Indeed, private lands provide important habitat for a significant number of species listed under the Endangered Species Act ("ESA"); by one account, "[a]pproximately half of listed species have at least $80 \%$ of their habitat on private lands." ${ }^{153}$ TNC and

148. See John R. Nolon, Open Ground: Effective Local Strategies for Protecting Natural Resources 523-24 (2003). On the land trust movement and conservation easements, see generally Richard Brewer, Conservancy: The Land Trust Movement in America (2003); Sally K. Fairfax \& Darla Guenzler, Conservation Trusts (2001).

149. For the number of land trusts, see LAND Tr. AlL., https://perma.cc/U2GJ-M9FM. National, state, and local land trusts hold more than $\$ 2$ billion in endowment and dedicated funding to acquire and defend landholdings. LAND TR. ALL., supra note 3, at 17.

150. Land Tr. All., Number of Land Trusts and Acres Protected by State, Local and National Land Trusts as of December 31, 2015, https://perma.cc/H2A8$7 \mathrm{H} 45$.

151. Id.

152. Nancy A. McLaughlin, Conservation Easements-A Troubled Adolescence, 26 J. LAND, RESOURCES, \& ENVTL. L. 47, 51-52 (2005).

153. Jason F. Shogren, Benefits and Costs, in The Endangered Species Act at Thirty: Vol. 2: Conserving Biodiversity in Human-Dominated Landscapes 181, 182 (J. Michael Scott et al. eds., 2008); U.S. Gen. Accounting Office, GAO/RCED-95-16, Endangered Species Act: Information on Species Protection on Nonfederal LANDS 4-5 (1994); see also Groves et al., supra note 127, at 283 ("Private lands harbor at 
other land trusts regularly employ scientific principles to assess how fee simple or conservation easement purchases fit into the larger landscape, ${ }^{154}$ which includes taking account of nearby public lands. ${ }^{155}$ In several instances, strategic private land conservation acquisitions have effectively expanded the protected public land base. In southern Colorado, for example, TNC has acquired two large ranches next to Great Sand Dunes National Park, significantly augmenting the federal preservation effort across the San Luis Valley. ${ }^{156}$ In northern Montana, the American Prairie Reserve has acquired ownership or easement rights on more than 270,000 acres of private ranch lands proximate to the Missouri Breaks National Monument and the Charles Russell National Wildlife Refuge with the goal of restoring bison and other native wildlife on this high plains landscape. ${ }^{157}$ In the Greater Yellowstone country, land trusts in Montana, Wyoming and Idaho have placed more than 750,000 acres in protected status, representing more than $11 \%$ of the privately owned lands in the region, to help facilitate wildlife movement, reduce habitat fragmentation, and safeguard water sources. ${ }^{158}$ Notwithstanding persistent legal issues regarding the enforcement and permanence of conservation easements, ${ }^{159}$ land trusts have assumed an important role in the nature conservation movement and provide opportunities to combine public and private conservation initiatives in order to protect critical landscapes at an ecologically meaningful scale.

least one population of more than . . . two thirds of federally listed species."); id. at 278-83 (noting that roughly forty percent of the federally listed species are not represented on federal lands). Moreover, one quarter of the major terrestrial and wetland ecosystems are poorly represented within the federal estate. David W. Crumpacker et al., A Preliminary Assessment of the Status of Major Terrestrial and Wetland Ecosystems on Federal and Indian Lands in the United States, 2 Conservation Biology 103, 111-14 (1988).

154. See Bruce A. Stein \& Frank W. Davis, Discovering Life in America: Tools and Techniques of Biodiversity Inventory, in Precious Heritage, supra note 127, at 19, 23-27; Mark L. Shaffer \& Bruce A. Stein, Safeguarding Our Precious Heritage, in Precious Heritage, supra note 127, at 301, 314-17.

155. See Lynn Scarlett, Our Connection to the Parks, Nature Conservancy Mag. 52, June/July 2016, https://perma.cc/8G4F-VV3F.

156. See infra notes 341-345 and accompanying text.

157. See infra notes 346-350 and accompanying text.

158. Personal communication with Andrew Hansen \& Linda Phillips, Ecology Dep't, Mont. State Univ. (Feb. 23, 2017) (data derived from U.S. Geological Survey, PAD v1.3) (on file with author). These figures are based on 6,687,869 acres of privately owned land within the Greater Yellowstone Ecosystem (“GYE”). See infra notes 297-313 and accompanying text describing GYE conservation efforts.

159. See Nancy A. McLaughlin, Tax-Deductible Conservation Easements and the Essential Perpetuity Requirements, 37 VA. Tax Rev. 1 (2017); Nancy A. McLaughlin, Conservation Easements: Perpetuity and Beyond, 34 Ecology L.Q. 673, 673-74 (2007). 


\section{An Evolving Nature Conservation Commitment}

Just as the nation's protected land base has evolved over time, so too has the rationale for protecting public and private lands. Although science has long played a role on the public lands, the emergence of the ecological sciences during the latter half of the twentieth century has added an important new dimension to the nation's nature conservation efforts, both in terms of designation decisions and management policies. No one can deny that the human presence, including the sheer size of the nation's swelling population as well as an everexpanding industrial footprint, has dramatically altered the natural world that has long helped to define the American experience. The related disciplines of ecology and conservation biology have brought forth new knowledge and strategies for preserving nature in today's world, along with an urgent understanding of the need for action in light of mounting biodiversity losses and climate change impacts. ${ }^{160}$ Congress, the federal agencies, and the federal courts have been paying noticeable attention to this accumulating scientific knowledge, as reflected in new legislative provisions, administrative initiatives, and judicial decisions.

\section{A. The Role of Science in Nature Conservation}

The notion that science should occupy a central role in nature conservation has persisted since at least the early twentieth century. In 1917, the National Research Council sought the assistance of the Ecological Society of America to develop a "listing of all preserved and preservable [sic] areas in North America in which natural conditions persist" and "to urge the reservation of such areas as demanded immediate attention." ${ }^{161}$ The Ecological Society of America prepared the requested report, followed by Victor Shelford's 1926 book entitled Naturalist's Guide to the Americas, that made the case for protecting natural areas, identified the nation's existing natural areas, and assessed their current condition. ${ }^{162}$ During the 1930s, George Melendez Wright, an engaging young wildlife biologist with the National Park Service, published a landmark series of "Faunal Survey" reports that beseeched the Agency to reverse its heavy-handed wildlife management policies, called for ecologically sensitive park boundary adjustments, and even proposed buffer zones to help safeguard park wildlife

160. See, e.g., Climate and Conservation (Jodi A. Hilty et al. eds., 2012); Evolutionary Perspectives on Environmental Problems 252 (Dustin J. Penn \& Iver Mysterud eds., 2d ed. 2009); Conservation Biology: Research Priorities for the Next Decade 178 (Michael E. Soulé \& Gordon H. Orians eds., 2001).

161. J. Michael Scott, A Representative Biological Reserve System for the United States, 6 Soc. Conservation Biology Newsl. 1 (1999); Preservation of Natural Areas, 1 Ecology 57 (1920).

162. Naturalist's Guide to the Americas (Victor E. Shelford et al. eds., 1926). 
populations. ${ }^{163}$ From its inception, the Forest Service endorsed a science-based management philosophy, namely Gifford Pinchot's "scientific utilitarianism" (or "wise use") policy geared to sustain resource production on the public forests, but showed little regard for nature conservation during its early years. ${ }^{164}$ Early proponents of the nascent wildlife refuge program recognized the realities of wild bird migration patterns and set about designing a system of refuges tracking the principal continental flyways, ${ }^{165}$ an obvious effort to incorporate early scientific insights into this wildlife salvation effort.

By the mid-twentieth century, the science of ecology was beginning to reshape federal natural resource management policies, including nature conservation strategies. Once scientists understood the dynamic and often unpredictable nature of ecosystems, it became evident that the conventional "balance of nature" paradigm represented an unworkable resource management goal. ${ }^{166}$ As the discipline of conservation biology and island biogeography theory took hold, scientists agreed that native species, to persist in the face of unrelenting human development pressures, would require the security of large protected reserves where nature rather than humankind dominated. ${ }^{167}$ Even within these reserves, to ensure genetic vigor and viable populations, scientists explained that isolated populations needed the opportunity to interact with other populations, hence giving recognition to the importance of connectivity in the form of wildlife migration or dispersal corridors. ${ }^{168}$ As a result, the concept of ecosystem

163. See George M. Wright \& Ben H. Thompson, Fauna of the National Parks of the United States: A Preliminary Survey of Faunal Relations in National Parks: Fauna Series No. 1, May 1932 (Gov. Printing Office 1933), reprinted in Dilsaver, supra note 26, at 109; George M. Wright \& Ben H. Thompson, Fauna of the National Parks of the United States: A Preliminary Survey of Faunal Relations in National Parks: Fauna Series No. 2, July 1934, Part II: Report Concerning the Characteristics of Buffer Areas (Gov. Printing Office 1935).

164. Charles F. Wilkinson, Crossing the Next Meridian: Land, Water, and the Future of the West 128-29 (1992).

165. See Fischman, supra note 6 , at 36 .

166. See Daniel B. Botkin, Discordant Harmonies: A New Ecology for the Twenty-First Century 155 (1990); Fikret Berkes, Shifting Perspectives on Resource Management: Resilience and the Reconceptualization of "Natural Resources" and "Management," 9 MAst 13, 19-21 (2010); Fred P. Bosselman \& A. Dan Tarlock, The Influence of Ecological Science on American Law: An Introduction, 69 CHI.-Kent L. Rev. 847, 863-73 (1994).

167. See Michael Soulé \& John Terborgh, The Policy and Science of Regional Conservation, in Continental Conservation, supra note 8, at 1, 6; Noss \& CoOperrider, supra note 8, at 138-42; Andrew J. Hansen \& Jay J. Rotella, Nature Reserves and Land Use: Implications of the "Place" Principle, in Applying Ecological Principles to Land Management 54 (Virginia H. Dale \& Richard A. Haeuber eds., 2001).

168. R. Travis Belote et al., Identifying Corridors among Large Protected Areas in the United States, 11 PLoS ONE 1, 1 (2016), https://perma.cc/H3U8-9CVC; Lynne Gilbert-Norton et. al., A Meta-Analytic Review of Corridor Effectiveness, 24 Conservation Biology 660, 667 (2010); Jeremy D. Dixon et al., Effectiveness of a Regional Corridor in Connecting Two Florida Black Bear Populations, 20 Conservation Biology 155, 155 (2006); see also Symposium, 
management rose to the fore as an essential strategy to promote nature conservation goals. ${ }^{169}$ To further bolster support for the concept, scientists called attention to the manifold social and economic benefits attached to the ecosystem services that nature provided, including water filtration, flood control, and nutrient cycling. ${ }^{170}$ This science-based movement toward ecologically-driven conservation was manifested quite clearly in changing federal policies toward wildfire, wetlands, and predators, ${ }^{171}$ all of which were coming to be seen as critical ecological factors on the landscape.

Within the scientific community, widespread agreement has emerged over the need to protect large areas in a natural state to safeguard native species and to permit vital ecological processes to unfold with minimal human intervention. ${ }^{172}$ This profound conclusion is based upon the indisputable fact that species are facing extinction at an accelerating pace primarily due to mounting human-driven pressures, including climate change, and the related loss of suitable habitat. ${ }^{173}$ One oft-cited study documented the extinction of several species within major U.S. national parks during the twentieth century, and concluded that the parks simply did not include sufficient habitat to sustain viable populations. ${ }^{174}$ Other studies have highlighted the increasing number of species listed under the ESA and the difficulties in recovering most protected species. ${ }^{175} \mathrm{Be}-$ cause the prevailing enclave theory of nature conservation has not been work-

Animal Migration Conservation, 41 EnvTL. L. 277 (2011) (examining the science, law, and policy for migration corridors); Mark R. Thompson, Keeping the Door Open: Protecting Biological Corridors with Existing Federal Statutes, 34 EnVTL. L. 703 (2004) (assessing the legal basis for protecting migratory corridors).

169. Keiter, supra note 10, at 48-49; SKILlen, supra note 10, at 142. See generally Steven L. Yaffee et al., Ecosystem Management in the United States: Assessment of Current Experience (1996) (listing more than 600 ecosystem management projects).

170. See generally Nature's Services: Societal Dependence on Natural Ecosystems (Gretchen Dailey ed., 1997); James Saltzman et al., Protecting Ecosystem Services: Science, Economics, and Law, 20 STAN. EnVTL. L.J. 309 (2001).

171. See Keiter, supra note 10, at 128-41.

172. See Reed F. Noss et al., Core Areas: Where Nature Reigns, in Continental ConservaTiOn, supra note 8, at 99; see also DAvid QuAmmen, Song of THE Dodo 491, 493-94 (1997) (explaining the role of preserves in nature conservation).

173. See Lawrence L. Master et al., Vanishing Assets: Conservation Status of U.S. Species, in PreCious Heritage, supra note 127, at 93, 95; David S. Wilcove et al., Leading Threats to Biodiversity: What's Imperiling U.S. Species, in Precious Heritage, supra note 127, at 239-40.

174. See Newmark, Extinction of Mammal Populations in Western North American National Parks, supra note 29, at 197, 205; Newmark, Legal and Biotic Boundaries of Western North American National Parks: A Problem of Congruence, supra note 29, at 521.

175. E.g., Maile C. Neel et al., By the Numbers: How is Recovery Defined by the US Endangered Species Act?, 62 BioScI. 646 (2012); Jeffrey Rachlinski, Noab by the Numbers: An Empirical Evaluation of the Endangered Species Act, 82 CoRnell L. Rev. 356 (1997) (book review); see also David Samuel Wilcove, The Condor's Shadow: The Loss and Recovery of WildLIFE IN AMERICA (1999) (providing an overview of species recovery efforts). 
ing, biologists have recommended a "3r's" strategy—representation, resiliency, and redundancy — for designing and maintaining a system of large protected natural areas. ${ }^{176}$ They have also argued that these protected areas need to be connected to facilitate species movement and genetic interchange. ${ }^{177}$ And they have endorsed the related concepts of ecosystem management and landscape conservation as policy priorities, ${ }^{178}$ both of which require coordinated planning and management among federal, state, tribal, and local entities as well as private landowners. ${ }^{179}$ Moreover, using sophisticated computer modeling and mapping techniques, they have graphically demonstrated the ecological "gaps" or shortcomings in our current protected land systems, ${ }^{180}$ while also showing where existing protected areas might be connected to facilitate species movement. ${ }^{181}$

To address the impact of climate change and other environmental stressors on wildlife and ecosystems, scientists have endorsed adaptive conservation strategies designed to promote ecological integrity and resiliency. Because warming temperatures are expected to cause considerable ecological disruption and uncertainty, the goal is to manage the risks facing wildlife and ecosystems to pre-

176. See Jocelyn L. Aycrigg et al., Completing the System: Opportunities and Challenges for a National Habitat Conservation System, 66 BIoScI. 774, 776 (2016); Leona K. Svancara et al., Policy-Driven versus Evidence Based Conservation: A Review of Political Targets and Biological Needs, 55 BioSci. 989, 989-91, 983 (2005); Mark L. Shaffer \& Bruce A. Stein, Safeguarding Our Precious Heritage, in Precious Heritage, supra note 127, at 307-10. Sometimes as part of this "3r's" strategy and sometimes separately, scientists and other knowledgeable observers have added a fourth " $\mathrm{r}$ " to the strategy_- "restoration" - recognizing that the natural environment has been widely altered by human activities over the centuries and it will be necessary to restore many degraded areas to a more natural condition to achieve modern conservation goals. See KeIter, To Conserve Unimpaired, supra note 28, at 249-52; see infra notes 407-411 and accompanying text for additional discussion of the 3r's policy and criteria of establishing nature reserves.

177. See Belote et al., supra note 168; Andy Dobson et al., Corridors: Reconnecting Fragmented Landscapes, in Continental Conservation, supra note 8, at 129. For an ambitious and detailed proposal to significantly expand and connect federal protected lands, see DAvE Foreman, Rewilding North America: A Vision for Conservation in the 21st Century (2004).

178. Shaffer \& Stein, supra note 176, at 314-16; Aycrigg et al., supra note 176, at 775-76; Craig R. Groves et al., Planning for Biodiversity Conservation: Putting Conservation Science into Practice, 52 BioScI. 499, 499-500 (2002).

179. On the role of coordination and collaboration in ecosystem management, see KeITER, supra note 10, at 220-21; Julia M. Wondolleck \& Steven L. Yaffee, Making Collaboration Work: Lessons from Innovation in Natural Resource Management 26-45 (2000).

180. See, e.g., Jocelyn L. Aycrigg et al., Representation of Ecological Systems within the Protected Areas Network of the Continental United States, PLoS ONE (2013), https://perma.cc/R57FTDG6; J. Michael Scott et al., Nature Preserves: Do They Capture the Full Range of America's Biological Diversity?, 11 Ecological Applications 999 (2001).

181. Belote et al., supra note 168, at 11; Jenny L. McGuire et al., Achieving Climate Connectivity in a Fragmented Landscape, 113 Proc. NAT'L ACAD. SCI. 7195 (2016). 
serve population viability and to maintain ecological processes within the range of historical variability. This requires an adaptive management strategy, which entails establishing baseline conditions, monitoring ecological changes (including ecosystem integrity, wildlife behavior, and habitat availability), assessing the effectiveness of any chosen strategy, and then readjusting management approaches in response to unanticipated changes and developments. ${ }^{182}$ To implement these adaptive, ecologically-based management approaches in a warming world, the agencies could find themselves engaging in more active management practices within nature reserves than is currently the practice. ${ }^{183}$ Some scientists, for example, support the concept of "assisted translocation" to relocate displaced species to more suitable habitat when they may be unable to move on their own. ${ }^{184}$ These suggested responses to climate change for nature conservation purposes mirror existing ecosystem-based management strategies and present many of the same challenges that have confronted other recent efforts to preserve ecosystem integrity and biodiversity.

To reduce the risk of extinction and to promote ecological resiliency, scientists have coalesced around three related management approaches. They are: 1) landscape-scale planning that takes a long-term temporal perspective, includes coordination across jurisdictional boundaries, and identifies connective corridors to enable species to disperse; ${ }^{185}$ 2) adaptive management strategies that enable managers to respond knowledgeably to ecological changes; ${ }^{186}$ and 3)

182. F. Stuart Chapin III et al., Planning in the Context of Uncertainty: Flexibility for Adapting to Change, in Beyond Naturalness: Rethinking Park and Wilderness Stewardship in an Era of Rapid Change 216, 223-25 (David N. Cole \& Laurie Yung eds., 2010). On adaptive management, see Adaptive Environmental Assessment and ManageMENT (Carl S. Holling et al. eds., 1978); Bernard T. Bormann et al., Adaptive Management of Forest Ecosystems: Did Some Rubber Hit the Road?, 57 BioScI. 186, 187 (2007); Robin Kundis Craig, "Stationarity is Dead"-Long Live Transformation: Five Principles for Climate Change Adaptation Law, 34 Harv. Envtl. L. Rev. 9 (2010); John D. Leshy, Federal Lands in the Twenty-first Century, 50 Nat. Resources J. 111, 124-31 (2010); J.B. Ruhl \& Robert L. Fischman, Adaptive Management in the Courts, 95 MinN. L. REv. 424, 427-43 (2010); Robert L. Glicksman, Ecosystem Resilience to Disruptions Linked to Global Climate Change: An Adaptive Approach to Federal Land Management, 87 Neb. L. Rev. 833, 868-71 (2000).

183. William C. Tweed, Uncertain Path: A Search for the Future of National PARKS 195-96 (2010).

184. See Alejandro E. Camacho, Assisted Migration: Redefining Nature and Natural Resources Law under Climate Change, 27 Yale J. on Reg. 171, 173-74 (2010); Scott R. Loss et al., Assisted Colonization: Integrating Conservation Strategies in the Face of Climate Change, 144 Biological Conservation 92, 93 (2011).

185. See Groves et al., supra note 178; Jody A. Hilty et al., Moving Forward on Climate Change Science, Planning and Action, in Climate And Conservation, supra note 160, at 281; Peter S. White et al., Conservation at Large Scales: Systems of Protected Areas and Protected Areas in the Matrix, in Beyond Naturalness: Rethinking Park and Wilderness Stewardship in An Era of Rapid Change 197, 197 (David N. Cole \& Laurie Yung eds., 2010).

186. On adaptive management, see supra note 182 and accompanying text. 
an expanded and reconfigured nature reserve system that promotes ecological resiliency by providing adequate sanctuary for threatened or displaced species. ${ }^{187}$ To implement these ecologically-based, nature conservation strategies, land managers must also account for related economic and social concerns by collaborating with potentially affected communities and landowners, whose engagement with the conservation effort is likely to be important to its success. ${ }^{188}$ As we shall see, several tools are available to land managers to promote collaborative conservation initiatives, including various legal provisions that generally promote public involvement in conservation efforts. ${ }^{189}$

The benefits of such an ecology-based approach to nature conservation are evident. First, a connected network of nature reserves combined with a related landscape conservation management strategy represents the best opportunity to avert extinctions and to protect ecosystems vital to humanity and nature as we know it. Second, preserving ecosystems and their all-important functions and processes is a necessary step toward ensuring a sustainable future for present as well as subsequent generations. Third, the ecological services derived from healthy ecosystems provide substantial economic and related benefits for human welfare. Fourth, preserving wildlife and other important components of the natural environment offers numerous recreational, aesthetic, and spiritual benefits that enrich society. Finally, by protecting largely undisturbed natural areas, scientists and others have a baseline that enables them to identify, measure, and understand environmental changes affecting the planet, including climate change. ${ }^{190}$

\section{B. Law, Ecology, and Nature Conservation}

Federal law and policy endorse — and have incorporated—key scientific insights embodied in contemporary nature conservation principles. To be sure, this process of endorsement and incorporation is incomplete and fragmentary (and not without counterexamples), but it is nonetheless undeniable. Congress, the President, the land management agencies, and the federal courts have each contributed to an emerging national policy of nature conservation and ecosystem preservation on the public lands. A somewhat similar transformation to-

187. See Charles C. Chester et al., Climate Change Science, Impacts, and Opportunities, in CLImate AND Conservation, supra note 160, at 3, 9-13; Groves et al., supra note 178; White et al., supra note 185.

188. See Matthew McKinney et al., Large Landscape Conservation: A Strategic Framework for Policy and Action 18-20 (2010); Wondolleck \& YAffee, supra note 179, at 30-35; Steven L. Yaffee, Collaboration Case Study: Collaborative Strategies for Managing Animal Migrations: Insights from the History of Ecosystem-Based Management, 41 ENVTL. L. 655, 679 (2011).

189. See infra notes 233-235 and accompanying text.

190. See Aycrigg et al., supra note 176, at 776. 
ward nature conservation is also taking hold on privately owned lands, abetted by developments in both federal and state law.

\section{Congress: Setting the Nation's Conservation Policy}

Under the Constitution, Congress is expressly granted authority over the nation's public lands. ${ }^{191}$ Congress's approach to public land policy has gradually but unmistakably shifted during the past century toward recognizing nature conservation as a national priority and incorporating science-based principles into the various laws governing the public domain. This shift is quite pronounced with the national park system, where Congress has consistently increased the size of the system and expanded existing parks, plainly taking ecological concerns into account with these actions. It is also evident in congressional legislation establishing the wilderness system and overseeing the national wildlife refuge system. Beyond these protected lands, ample additional evidence shows that Congress is aware of important ecological concepts and has incorporated them into the basic laws governing the public lands.

In the case of the national parks, where Congress originally set aside lands as new park units based primarily on their scenic (and often mountainous) splendor, it notably departed from this model in 1934 with the establishment of Everglades National Park, convinced by the park's proponents that the area's ecological and wilderness qualities merited the designation. ${ }^{192}$ Since then, Congress has continued to add new ecologically diverse areas to the system, including Channel Island National Park off the southern California coast, ${ }^{193}$ Voyageurs National Park in northern Minnesota, ${ }^{194}$ and Congaree National Park embracing unique swamp lands in South Carolina. ${ }^{195}$ In the 1980 ANILCA, Congress sought to "preserve in their natural state extensive unaltered . . ecosystems." ${ }^{196}$ In 1994, Congress significantly expanded Death Valley and Joshua Tree national parks and also designated several new wilderness areas, creating a multi-million acre complex of protected federal lands in the

191. See U.S. Const., art. IV, § 3; Kleppe v. New Mexico, 426 U.S. 529, 539 (1976) (“[W]e have repeatedly observed that " $\mathrm{t}]$ he power over the public lands thus entrusted to Congress is without limitations.'”) (quoting United States v. San Francisco, 310 U.S. 16, 29 (1940)).

192. RuNTE, supra note 14 , at 133-37.

193. 16 U.S.C. $\S 410 \mathrm{ff}(2012)$.

194. Id. § 160 .

195. Id. $\S 410 \mathrm{jjj}$. Other examples of Congress's expansion of ecosystem diversity within the national park system include: Big Bend National Park on the Texas-Mexico border, 16 U.S.C. $\S 156$ (2012), Redwood National Park in northern California, 16 U.S.C. § 79a (2012), Virgin Islands National Park in the Caribbean, 16 U.S.C. $\$ 398$ (2012), and Tall Grass Prairie National Preserve in Kansas, 16 U.S.C. $§ 698$ u (2012).

196. ANILCA, 16 U.S.C. §3101(b) (2012). In ANILCA, Congress also urged that national park and other conservation unit boundaries adhere to "topographic or natural features." Id. $\S 3103(\mathrm{~b})$; see supra note 23 and accompanying text. 
California desert landscape. ${ }^{197}$ In fact, a quick perusal of national park legislation over time reveals numerous instances-Grand Canyon, Yosemite, and Redwood being prime examples-where Congress has enlarged existing park boundaries to better protect native wildlife habitat, watersheds, and other threatened resources. The 1998 addition of several science-focused provisions to the National Park Service Organic Act, not only expanded the Agency's statutory mission, but also extended its new scientific study responsibilities to "the larger region of which parks are a part."198

Congressional legislation governing the nation's other protected public lands reflects a similar trend toward enlarging the systems and employing science in their management. The landmark Wilderness Act of 1964 set the framework for the national wilderness preservation system, which Congress has gradually expanded to encompass more than 110 million acres where nature is largely left alone without human intervention. ${ }^{199}$ The act explicitly acknowledges that the concept of "wilderness" embraces "ecological, geological, or other features of scientific . . . value," 200 thus inserting science-based considerations into wilderness designation and management processes. Over the years, Congress has likewise expanded the national wildlife refuge system, growing it to embrace 95 million acres that extend across a diverse array of ecosystems. ${ }^{201}$ In the National Wildlife Refuge System Improvement Act of 1997, Congress not only established a "biological integrity, diversity, and environmental health" management standard for the refuge system, ${ }^{202}$ but also included a monitoring provision to measure progress toward meeting these science-based standards. ${ }^{203}$ Under the Wild and Scenic Rivers Act of 1968, which includes nearly 13,000 miles of river segments across the country, Congress sought to protect freeflowing rivers and riparian corridors, giving management priority to "protecting . . . esthetic, scenic, historic, archeologic, and scientific features." ${ }^{204}$ In 2014, Congress officially endorsed the NLCS, making the BLM responsible for 32 million acres of wilderness, national monuments, and other conservation-oriented lands. Moreover, the Land and Water Conservation Fund Act of 1965

197. California Desert Protection Act of 1994, Pub. L. No. 103-433, 108 Stat. 4485 (1994) (codified at 16 U.S.C. §§ 410aaa to 410aaa-83 (2012)); see also infra notes 322-331 and accompanying text (describing conservation efforts in the California desert area).

198. 16 U.S.C. $§ 5931$ (2012) et seq.; 16 U.S.C. § 5933 (2012) (referring to the "larger region") (Sections 5931 and 5933 have been repealed.).

199. See supra notes 54-77 and accompanying text for a description of the evolution of the national wilderness preservation system.

200. 16 U.S.C. $\S 1131$ (c).

201. See supra notes $46-48$ and accompanying text.

202. 16 U.S.C. $\S 668 \mathrm{dd}(\mathrm{a})(4)(\mathrm{B})$ (2012). The Act also mandates a comprehensive conservation planning process that is to be coordinated with agencies and landowners beyond refuge boundaries. $I d$. $\S 668 \mathrm{dd}(\mathrm{a})(4)(\mathrm{C}),(\mathrm{E}),(\mathrm{M}), \S 668 \mathrm{dd}(\mathrm{e})(3)(\mathrm{A})$.

203. Id. $\S 668 \mathrm{dd}(\mathrm{a})(4)(\mathrm{N})$.

204. Id. $\S 1281(\mathrm{a})$; see supra notes $108-116$ and accompanying text. 
makes federal funding available to the federal land management agencies to purchase lands for recreation and conservation purposes, ${ }^{205}$ thus enabling federal land managers to better secure the ecological integrity of their protected lands.

Beyond the protected land systems, Congress has incorporated important scientific and biological concepts into federal public land laws and related environmental legislation. In the landmark ESA of $1973,{ }^{206}$ Congress set averting species extinction as a priority national goal, ${ }^{207}$ and then stated that the law's purpose was "to provide a means whereby the ecosystems upon which endangered species and threatened species depend may be conserved." 208 The Act mandates that species "listing" decisions are to be made "solely on the basis of the best scientific and commercial data available," ${ }^{209}$ grants regulatory authority to the FWS, empowering it to essentially veto any federal action that would jeopardize a protected species or adversely affect its habitat, ${ }^{210}$ and prohibits anyone, including private landowners, from "taking" a "listed" species. ${ }^{211}$ In the National Forest Management Act of 1976 ("NFMA"), Congress included an express diversity provision instructing the Forest Service to provide for animal and plant diversity in its planning and management decisions, ${ }^{212}$ which the courts and the agency have imbued with real legal teeth. ${ }^{213}$ And the NFMA contains inventory and monitoring provisions integral to an ecologically-based adaptive management approach. ${ }^{214}$ The National Environmental Policy Act ("NEPA") requires federal agencies to prepare an environmental analysis before undertaking any major federal action significantly affecting the human environment, ${ }^{215} \mathrm{a}$ mandate that has been interpreted through implementing regulations to compel agencies to examine the cumulative impacts of any proposal, ${ }^{216}$ which essentially requires them to take account of the landscape as a whole. These statutory provisions plainly demonstrate that Congress, while perhaps not prepared to fully embrace a science-driven agenda for managing the public lands, is

205. 54 U.S.C. § 200306 (2012); see also infra notes 263-265 and accompanying text.

206. 16 U.S.C. $\S \S 1531-1541$ (2012).

207. See Tenn. Valley Auth. v. Hill, 437 U.S. 153, 175 (1978).

208. 16 U.S.C. $\S 1531$ (b) (2012).

209. 16 U.S.C. $\S 1533(\mathrm{~b})(2012)$.

210. See id. § 1536(a)(2); Bennett v. Spear, 520 U.S. 154, 157-58 (1997).

211. 16 U.S.C. $§ 1538(a)(1)(B)(2012)$; Babbitt v. Sweet Home Chapter, 515 U.S. 687, 690 (1995).

212. 16 U.S.C. $\S 1604(\mathrm{~g})(3)(\mathrm{B})(2012)$.

213. See, e.g., Utah Envtl. Cong. v. Bosworth, 439 F.3d 1184, 1190-94 (10th Cir. 2006); Sierra Club v. Martin, 168 F.3d 1, 5-8 (11th Cir. 1999); see also infra notes 217-218, 246-247 and accompanying text (further examining the NFMA diversity provision).

214. 16 U.S.C. $§ 1604(\mathrm{~g})(2)(\mathrm{B}),(\mathrm{g})(3)(\mathrm{C})(2012)$; see infra notes 238-239 and accompanying text.

215. 42 U.S.C. $\S 4332($ C) $(2012)$.

216. 40 C.F.R. $\S 1508.25$ (c)(3) (1978); Thomas v. Peterson, 753 F.2d 754, 759 (9th Cir. 1985). 
nonetheless cognizant of ecological principles as it goes about overseeing the nation's vast federal estate.

\section{The Agencies: Rules, Policies, and Practices}

Drawing upon these statutory authorities, the federal land management agencies have each promulgated extensive rules and policies requiring that planning and management decisions take account of the larger landscape within which these decisions are being made. The Forest Service's NFMA-based 2012 planning regulations instruct agency officials to prepare pre-plan assessments that "describe the plan area's distinctive roles and contributions within the broader landscape," including "dominant ecological processes, disturbance regimes, and stressors." 217 The regulations also require forest managers to use "the best available science," to ensure "ecological sustainability," and to promote "ecosystem integrity" by considering, among other things, "landscape-scale restoration" and "ecological connectivity" opportunities. ${ }^{218}$ Until Congress intervened in March 2017, the BLM's newly revised planning regulations required agency officials to consider environmental and ecological conditions at an appropriate scale in the resource management planning process, which included a pre-plan assessment documenting and assessing such factors as wildlife habitat, areas of ecological importance, ecological processes, disturbance regimes, and "the degree of local, regional, national or international importance of these goods, services, and uses." ${ }^{19}$ The Park Service's Management Policies, recognizing that "parks are integral parts of larger regional environments," instruct park managers to pursue "cooperative conservation" strategies in order to avoid or mitigate adverse impacts on park resources and values from external activities by engaging neighbors in collaborative processes. ${ }^{220}$ The FWS's policies direct

217. 36 C.F.R $\S 219.6(b)(3), 219.7(f)(2012)$.

218. 36 C.F.R § 219.3 (2017); 36 C.F.R § 219.8(a) (2017); 36 C.F.R. § 219.9(a) (2017).

219. BLM Resource Management Planning Rule, 81 Fed. Reg. 89,580, 89,663, 89,666-67 (Dec. 12, 2016) (would have been codified at 43 C.F.R. pt. 1600). In late March 2017, Congress used its authority under the Congressional Review Act to disapprove this new planning rule, sending the BLM back to the drawing board. See Act of March 27, 2017, Pub. L. No. 11512, 131 Stat. 76. It remains to be seen whether landscape-scale concerns are incorporated into the agency's next rule revisions. Regardless, the FLPMA planning provisions require BLM land-use plans to include "integrated consideration of physical, biological, economic, and other sciences," to "give priority to the designation and protection of areas of critical environmental concern," and to "weigh long-term benefits to the public against short-term benefits.” 43 U.S.C. § 1712(c) (2015); see also 43 U.S.C. § 1701(a)(8) (2015) (identifying the congressional policy that "public lands be managed in a manner that will protect the quality of scientific, scenic, historical, ecological, environmental, air and atmospheric, water resource, and archeological values; ... [and] that will provide food and habitat for fish and wildlife and domestic animals").

220. NPS Management Policies, supra note 34, at 13, 31, 38. See generally Nat'l Park Serv., Scaling Up: Collaborative Approaches to Large Landscape Conserva- 
refuge managers to "consider their refuge's contribution to [ecological integrity] at multiple landscape scales" and to consider effects on the wider ecosystem approach in planning and management. ${ }^{221}$

The agencies and the President have taken other explicit actions designed to advance conservation values on the public lands. In 2000, as we have seen, the Forest Service promulgated a roadless area rule that prohibited road building and new industrial activity on 58.5 million acres of national forest land in large part to protect wildlife resources and to minimize fragmentation of these extensive undisturbed areas.222 On several occasions, presidents have utilized their authority under the Antiquities Act to designate expansive new national monuments, and to situate new monuments adjacent to other federally protected lands, de facto expanding the existing protected area and often helping to connect it with other protected lands.223 President Obama's 2017 proclamation expanding the boundaries of the Cascade-Siskiyou National Monument in southern Oregon cites the area's "particularly significant ecological connectivity and integrity" to justify the enlargement. ${ }^{224}$ Moreover, the Secretary of the Interior has employed FLPMA's statutory withdrawal authority to preclude mining and other industrial activities on sensitive lands harboring important conservation values or bordering protected lands. ${ }^{225}$ In the case of Grand Canyon National Park, for example, the Secretary has withdrawn more than one million acres to prevent new uranium mining claims on national forest and BLM lands adjacent to the national park..$^{226}$

TION (2014), https://perma.cc/VV42-7Y7V (providing examples of where the National Park Service is engaging in landscape-scale conservation through collaborative approaches).

221. Policy on Maintaining the Biological Integrity, Diversity, and Environmental Health of National Wildlife Refuge System, 66 Fed. Reg. 3810, 3818-19 (Jan. 16, 2001). Here, the term "ecological integrity" covers the agency's three related management standards: "biological integrity, diversity, and environmental health." Id. at 3818; see supra note 53 and accompanying text.

222. See supra notes $101-107$ and accompanying text.

223. See, e.g., infra note 333 and accompanying text (noting that President Clinton designated two large national monuments adjacent to Grand Canyon National Park: the Grand Canyon-Parashant National Monument and the Vermillion Cliffs National Monument).

224. Proclamation No. 9564, Boundary Enlargement of the Cascade-Siskiyou National Monument, 82 Fed. Reg. 6145, 6147 (Jan. 18, 2017).

225. 43 U.S.C. $§ 1716(d)(2012)$; see e.g., Pub. Land Order No. 7787, Withdrawal of Public and National Forest System Land in the Grand Canyon Watershed, Arizona, 77 Fed. Reg. 2563 (Jan. 18, 2012) (withdrawing from mining more than one million acres adjacent to Grand Canyon National Park); Pub. Land Order No. 7480, Withdrawal of National Forest System Lands in the Rocky Mountain Front, Montana, 66 Fed. Reg. 6657 (Jan. 22, 2001) (withdrawing from mining more than 400,000 acres of wildlife and culturally rich lands located near Glacier National Park).

226. See infra notes 335-336 and accompanying text. A similar withdrawal from mining activity was made recently in the Greater Yellowstone region. See BLM Notice of Application for 
Moreover, the land management agencies have incorporated landscapescale planning and related ecological considerations into their institutional structures and practices. Pursuant to a series of secretarial orders, ${ }^{227}$ the agencies have embraced the concept of landscape conservation, both as a response to climate change concerns and as a means to maintain resilient ecosystems. One clear manifestation of this commitment is the establishment of the Landscape Conservation Cooperatives Network ("LCCs"), ${ }^{228}$ an interagency initiative designed to promote landscape-scale conservation, which is defined as "an ecologically connected network of landscapes and seascapes adaptable to global change—-such as climate change-with the ability to sustain ecological integrity and health to meet the needs of society at multiple scales."229 The BLM, as part of its commitment to landscape-scale conservation, has undertaken a series of Rapid Ecoregional Assessments to identify ecological conditions and trends as well as important resource values on the Colorado Plateau, Sonoran Desert, Mojave Basin and Range, and in other ecoregions in order to better inform management decisions concerning "climate change, wildfire, and other environmental challenges that transcend local administrative boundaries."230 And the BLM, faced with recurrent controversies over oil and gas development near national parks and other protected areas, has established a new Master Lease Planning process designed to enable agency officials to identify and avoid potential conflicts with national park lands and other sensitive resources located on the broader landscape before offering leases for sale. ${ }^{231} \mathrm{~A}$ similar commit-

Withdrawal and Notification of Public Meeting; Montana, 81 Fed. Reg. 83,867 (Nov. 22, 2016).

227. Sec'y of the Interior, Order No. 3289, Amendment No. 1 (Feb. 22, 2010); Sec'y of the Interior, Order No. 3330 (Oct. 13, 2013); see also Exec. Order No. 13,653, Preparing the United States for the Impacts of Climate Change, 78 Fed. Reg. 66,819 (Nov. 1, 2013); Presidential Memorandum: Mitigating Impacts on Natural Resources from Development and by Encouraging Related Private Investment (Nov. 3, 2015).

228. Sec'y of the Interior, Order No. 3289 (Sept. 14, 2009); NAT'L ACAD. OF SCI., supra note 10.

229. Landscape Conservation Coops., 2014 Network Strategic Plan 6 (2014), https:/ /perma.cc/WRL6-G2RQ. While still in its infancy, the LCC Network has as one of its objectives to "facilitate the design of an ecologically connected network of large geographic regions that support priority natural and cultural resources." $I d$. at 7 . To achieve its conservation goals, the 22 eco-regional LCCs are developing and utilizing scientific knowledge to promote collaborative conservation strategies. $I d$. at $8-11$.

230. Bureau of Land Mgmt., Rapid Ecoregional Assessments (2016), https://perma.cc/ P3FS-P7RG; U.S. Geological Survey, Multiscale Guidance and Tools for Implementing a Landscape Approach to Resource Management in the Bureau of Land Management 19-38 (Sarah K. Carter et al. eds., 2017).

231. See Bureau of Land Mgmt., Instr. Memo No. 2010-117 (May 17, 2010), https://perma.cc/ T3CS-X635. Bureau of Land Mgmt., Record of Decision and Moab Master Lease Planning/Approved Resource Management Plan Amendments for the Moab and Monticello Field Offices (Dec. 2016), https://perma.cc/BRA3-9L5K. The Master Lease Planning process was conceived by the Obama Administration in the aftermath of a controversy over oil 
ment to landscape conservation is evident in Forest Service, Park Service, and FWS rules and policies. ${ }^{232}$

The federal land management agencies have also embraced two key components of landscape scale planning, namely multi-agency coordination and adaptive management. The coordination concept speaks to the need to engage multiple players across the larger landscape to effectively address nature conservation concerns that typically transcend conventional boundary lines. The land management agencies are each governed by statutory coordination provisions embedded in their planning mandates, ${ }^{233}$ which have in turn been incorporated into agency rules and policies. ${ }^{234}$ Under the NFMA, the Forest Service is required to "coordinate land management planning with the equivalent and related planning efforts of federally recognized Indian Tribes, Alaska Native Corporations, other Federal agencies, and State and local governments," including reviewing their planning and land use policies and displaying this review in the plan Environmental Impact Statement ("EIS"). ${ }^{235}$ The ESA has also figured prominently in important interagency conservation efforts. During the 1980s, as we shall see, the ESA brought the federal land management agencies and state wildlife agencies together as an Interagency Grizzly Bear Committee to shepherd the nation's at-risk grizzly bear population toward recovery across key portions of its habitat. ${ }^{236}$ Faced with the prospect of the greater sage grouse being added to the federal endangered species list, the BLM and Forest

and gas leases issued in the final days of the George W. Bush Administration on BLM lands proximate to Arches and Canyonlands national parks and Dinosaur National Monument in Utah and other sensitive lands. See Impact Energy Res., LLC v. Salazar, 693 F.3d 1239 (10th Cir. 2012). The Trump Administration, given its interest in promoting energy development on public lands, appears committed to eliminating the Master Lease Planning process. U.S. Dep't of the Interior, Final Report: Review of the Department of the Interior Actions that Potentially Burden Domestic Energy 10-11 (2017).

232. See supra notes 217-221 and accompanying text.

233. See 16 U.S.C. $§ 1604(a)$ (2012) (Forest Service); 43 U.S.C. $§ 1712$ (c)(9) (2012) (BLM); 16 U.S.C. § 668dd(a)(4)(E), (M), 668dd(e)(3) (2012) (FWS); 54 U.S.C. § 100502 (2012) (National Park Service). Although the Park Service's general management plan statute does not have an explicit coordination requirement, the Agency has assumed a coordination responsibility in its Management Policies. See infra note 234. Moreover, The NEPA environmental review process, including the statute's consultation requirements and "cooperating agency" regulation, also promotes interagency coordination among the land management agencies and with relevant state and local agencies. 42 U.S.C. $\S 4332(\mathrm{C})$ (consultation with expert agencies); 42 C.F.R. $\S 1501.6,1508.5$ (2016) (cooperating agency status).

234. See 36 C.F.R. § 219.4(B) (2015) (Forest Service); 43 C.F.R. § 1610.3-1 (2015) (BLM); 50 C.F.R. § 29.2 (FWS); NPS Management Policies, supra note 34, at 1.6, 2.3.1.8, 4.1.4.

235. 36 C.F.R. § 219.4(b)(1), (2) (2015).

236. Interagency Grizzly Bear Comm., Story of the IGBC, https://perma.cc/7MGRYDDU; see infra notes 298-310 and accompanying text; see also infra notes 352-358 and accompanying text (explaining the role of the ESA-protected northern spotted owl in prompting the interagency Northwest Forest Plan). 
Service engaged in "an unprecedented coordinated collaboration among Federal land management agencies and the States to manage an entire [sagebrush steppe] ecosystem and associated flora and fauna"-an effort that covers 165 million acres across eleven states and also involves Native American tribes and private landowners. ${ }^{237}$ By regulation and policy, the land management agencies have endorsed basic adaptive management principles, including inventory, monitoring and reassessment requirements. ${ }^{238}$ The Forest Service's planning regulations, for example, instruct forest officials to prepare a monitoring program that addresses ecological conditions, watershed conditions, and changes related to climate change and other stressors, and to prepare a biennial monitoring report to determine whether to change the plan or management activities. ${ }^{239}$ With these binding commitments to interagency coordination and adaptive management protocols, two fundamental strategies supporting a landscape conservation approach to public land management are in place.

\section{The Courts: Giving Landscape Conservation Its Due}

The federal courts have also played a prominent role in promoting landscape-scale management concepts and in safeguarding protected areas from threatening activities. A federal judge compelled the Forest Service and the BLM to adopt the sprawling Northwest Forest Plan, ${ }^{240}$ thus implementing a protective new ecosystem management regime on 24 million acres extending across three states. ${ }^{241}$ Since then, the courts have also sustained the comprehensive Sierra Nevada Forest Plan amendments against various legal challenges, ${ }^{242}$

237. Bureau of Land Mgmt., Record of Decision and Approved Resource Management Plan Amendments for the Rocky Mountain Region S-2 (Sept. 2015). For general information about the sage grouse and sage grouse conservation, see U.S. FISH \& Wildlife Serv., The Greater Sage-Grouse, https:/perma.cc/8LGJ-DFES. The Trump Administration, however, is moving forward to amend the Obama Administration's sage grouse plan, seeking to reduce the level of protection available for the bird. Trump Sage Grouse Policy May Affect Litigation, 42 Pub. Lands News 1, 13 (Oct. 20, 2017).

238. See, e.g., 36 C.F.R. § 219.12 (2012) (Forest Service); 43 C.F.R. § 1610.6-4 (2016) (BLM); National Park System Management Policies, supra note 34, at 4.1.1. The statutory basis for adaptive management is found at 16 U.S.C. $\$ 1604$ (a) (2012) (Forest Service); 43 U.S.C. §§ 1711(a), 1712(c)(4) (2012) (BLM); 16 U.S.C. § 668dd(a)(4)(N), 668dd(e)(1)(E) (2012) (FWS).

239. See 36 C.F.R. $§ 219.12$ (2016).

240. Seattle Audubon Soc'y v. Evans, 771 F.Supp. 1081 (W.D. Wash. 1991), affd, 952 F.2d 297 (9th Cir. 1991); see also Seattle Audubon Soc'y v. Lyons, 871 F.Supp. 1291 (W.D. Wash. 1994), affd sub nom. Seattle Audubon Soc'y v. Moseley, 80 F.3d 1401 (9th Cir. 1996) (sustaining the Northwest Forest Plan against legal attack).

241. See infra note 352 and accompanying text. See generally KeITER, supra note 10, at 80-113.

242. U.S. Forest Serv., Sierra Nevada Forest Plan Amendment: Final Supplemental Environmental Impact Statement 1 (2004), https://perma.cc/YJ64-F3QG; Pac. Rivers Council v. U.S. Forest Serv., 942 F.Supp.2d 1014, 1034 (E.D. Cal. 2013) (finding 
effectively approving this large-scale ecosystem management initiative. By rigorously enforcing the ESA, the courts have elevated species conservation within the federal land management agencies and buttressed the notion of ecosystembased management. ${ }^{243}$ In Pacific Rivers Council v. Thomas, ${ }^{244}$ for example, the courts required the Forest Service to reinitiate consultation with the FWS on its existing forest plans when a new salmon species was added to the federal endangered species list and prohibited any logging or road construction activities on the two affected national forests pending re-consultation. ${ }^{245}$ The courts have also regularly invoked the NFMA's diversity provision and implementing regulations to enjoin timber, road construction, and other potentially damaging projects on the national forests, ${ }^{246}$ prompting one Forest Service Chief to suggest that biodiversity conservation has become the de facto resource management policy on the nation's federal forest lands. ${ }^{247}$ Under NEPA, ${ }^{248}$ the courts have rendered countless cumulative impact analysis decisions, requiring the land management agencies to take full account of the spatial and temporal

that the EIS was not seriously flawed and allowing the forest plan amendments to stand pending completion of a supplemental EIS); see infra notes 361-365 and accompanying text.

243. See Yaffee, Collaboration Case Study, supra note 188, at 677 ("I estimate that half of the [ecosystem-based management] collaborative processes we have studied have succeeded because they have a regulatory driver in the form of a federal-listed endangered or threatened species.").

244. 30 F.3d 1050 (9th Cir. 1994); see also Conner v. Burford, 848 F.2d 1441, 1462 (9th Cir. 1988) (requiring the FWS, under the ESA's section 7 consultation requirement, to prepare a comprehensive biological opinion examining future potential impacts following issuance of an oil and gas lease).

245. See also Native Ecosystems Council v. Dombeck, 304 F.3d 886, 900-03 (9th Cir. 2002) (finding that the Forest Service's analysis of the project's impact on grizzly bears did not include the full potential geographic impact of the project).

246. See, e.g., Native Ecosystems Council v. Tidwell, 599 F.3d 926, 933-36 (9th Cir. 2010); Utah Envtl. Cong. v. Bosworth, 439 F.3d 1184, 1190-91 (10th Cir. 2006); Sierra Club v. Martin, 168 F.3d 1, 5-7 (11th Cir. 1999); see also Robert B. Keiter, Ecological Concepts, Legal Standards, and Public Land Law: An Analysis and Assessment, 44 NAT. Resources J. 943, 945-52 (2004); James A. Siemans, A "Hard Look" at Biodiversity and the National Forest Management Act, 6 Tul. EnvTl. L.J. 157, 161-67 (1992).

247. Jack Ward Thomas, Stability and Predictability in Federal Forest Management: Some Thoughts from the Chief, 17 Pub. Land \& Resources L. Rev. 9, 15 (1996); see also Michael Dombeck, From Coneuest to Conservation: Our Public Lands Legacy 168-70 (2003) (promoting "ecological sustainability" as the guiding principle for multiple-use management); James Furnish, Toward a Natural Forest: The Forest Service in TrAnsition 191-200 (2014) (endorsing environmental values and a "natural forest" standard for future national forest management).

248. 42 U.S.C. $\S \S 4321-4370 \mathrm{~m}-12$ (2012). The EIS requirement is set forth in 42 U.S.C. $\S 4332(2)(\mathrm{C})(2012)$. 
dimensions of specific project proposals. ${ }^{249}$ In Native Ecosystems Council v. Dombeck, ${ }^{250}$ the court emphasized the importance of a comprehensive NEPA environmental review, ruling that the Forest Service failed to adequately address the likely impact of future road construction activities; rather than focusing on the particular timber sale area, the agency should have extended its analysis across the entire forest. The courts have also enforced, and in some cases compelled, agency adaptive management commitments, further legitimizing this key aspect of landscape conservation. ${ }^{251}$ In addition, the courts have begun requiring the agencies to address global warming impacts in their ESA and NEPA analyses, ${ }^{252}$ an obligation that should further encourage landscapelevel management decisions.

Moreover, the courts have been quite protective of wilderness-eligible lands threatened with potential development or intrusion, while also regularly affirming agency decisions giving priority to nature conservation over development and recreational interests. Early in the history of the Wilderness Act, the federal courts blocked a proposed logging project in a Colorado national forest on wilderness quality lands abutting a designated "primitive area" to ensure that these lands received consideration for wilderness designation. ${ }^{253}$ Since then, numerous court decisions have protected threatened areas on undeveloped public lands that harbor wilderness attributes. ${ }^{254}$ In Montana Wilderness Association v.

249. See, e.g., Idaho Sporting Cong. v. Rittenhouse, 305 F.3d 957 (9th Cir. 2002); Kern v. Bureau of Land Mgmt. 284 F.3d 1062 (9th Cir. 2002); Thomas v. Peterson, 753 F.2d 754 (9th Cir. 1985); Fund for Animals v. Hall, 448 F.Supp.2d 127 (D.D.C. 2006).

250. 304 F.3d 886 (9th Cir. 2002).

251. See generally Ruhl \& Fischman, supra note 182. Significantly, the authors observe that largerscale planning and decision processes provide a more effective setting for implementing meaningful adaptive management protocols. $I d$. at 447-56.

252. See Greater Yellowstone Coal. v. Servheen, 665 F.3d 1015, 1025 (9th Cir. 2011); Mont. Envtl. Info. Ctr. v. U.S. Office of Surface Mining, No. CV 15-106-M-DWM, 2017 U.S. Dist. LEXIS 129018, at *36-51 (D. Mont. Aug. 14, 2017); Defs. of Wildlife v. Jewell, 176 F.Supp.3d 975 (D. Mont. 2016); High Country Conservation Advocates v. U.S. Forest Serv., 52 F.Supp.3d 1174 (D. Colo. 2014); Nat. Res. Def. Council v. Kempthorne, 506 F.Supp.2d 322, 367-70 (E.D. Cal. 2007); see also Murray Feldman \& Andrew Mergen, The Role of Climate Change in ESA Decisions, 53 Rocky MTN. Min. L. Found. J. 67, 73-94 (2016); cf. Wild Earth Guardians v. U.S. Forest Serv., 120 F.Supp.3d 1237 (D. Wyo. 2015) (finding the agency's climate change analysis sufficient).

253. See generally Parker v. United States, 448 F.2d 793 (10th Cir. 1971).

254. See, e.g., Or. Nat. Desert Ass'n v. Bureau of Land Mgmt., 625 F.3d 1092 (9th Cir. 2010); New Mexico ex rel. Richardson v. Bureau of Land Mgmt., 565 F.3d 683 (10th Cir. 2009); Smith v. U.S. Forest Serv., 33 F.3d 1072 (9th Cir. 1994); Nw. Motorcycle Ass'n v. U.S. Dep't of Agric., 18 F.3d 1468 (9th Cir. 1994); California v. Block, 690 F.2d 753 (9th Cir. 1982); Greater Yellowstone Coal. v. Timchak, 2006 WL 3386731 No. CV-06-04-E-BLW, 2006 WL 3386731 (D. Idaho Nov. 21, 2006). 
McAllister, 255 for example, the court enjoined the Forest Service's proposed travel plan, because the agency did not account for the "wilderness study area" designation in assessing the impact of off-road vehicles and mountain bikes on the yet undisturbed landscape. The courts have consistently read the National Park Service Organic Act to give priority to the Agency's resource conservation obligations when in apparent conflict with its visitor enjoyment responsibilities. In Southern Utah Wilderness Alliance v. Dabney, ${ }^{256}$ the court sustained the Park Service's decision to disallow off-road vehicle access along Salt Creek in Canyonlands National Park, endorsing the Agency's conclusion that its organic "non-impairment" mandate prioritized resource protection over recreational activities that could harm this sensitive riparian area. Similarly, the courts have upheld the FWS's authority to regulate and even prohibit recreational and other activities that threaten a national wildlife refuge's primary wildlife conservation purposes..$^{257}$ These diverse judicial rulings, though not a complete endorsement of landscape-scale conservation concerns, nevertheless suggest that the courts are sensitive to the nature conservation implications embedded in agency decisions and willing to ensure that these implications are fully examined before resource management decisions are finalized..$^{258}$

\section{Conserving Private Lands under Federal and State Law}

Private land conservation activity has grown in recent years. This development reflects an emerging shift in landowner views toward nature conservation, linked in part to federal and state laws specifically designed to promote conservation on private lands. ${ }^{259}$ It can also be traced to Aldo Leopold's much-her-

255. 666 F.3d 549, 551 (9th Cir. 2011); see also Russell Country Sportsmen v. U.S. Forest Serv., 668 F.3d 1037 (9th Cir. 2011) (upholding Forest Service decision reducing motorized access to wilderness study areas).

256. See 387 F.Supp.2d 1178, 1193-96 (D. Utah 2005). For other cases reaching the same conclusion, see, e.g., Bicycle Trails Council v. Babbitt, 82 F.3d 1445, 1453 (9th Cir. 1996); Isle Royale Boaters Ass'n v. Norton, 330 F.3d 777 (6th Cir. 2003); Cape Hatteras Access Pres. All. v. Jewell, 28 F.Supp.3d 537 (E.D.N.C. 2014); Nat'1 Rifle Ass'n v. Potter, 628 F. Supp. 903 (D.D.C. 1986).

257. See Livingson v. United States, No. 2:15-CV-00564-DCN, 2016 WL 1274013, at *3-4 (D.S.C. Dec. 21, 2016); McGrail \& Rowley v. Babbitt, 986 F. Supp. 1386, 1392-94 (S.D. Fla. 1997) affd without opinion, 226 F.3d 646 (11th Cir. 2000); cf. Del. Audubon Soc'y v. Sec'y of the U.S. Dep't of Interior, 612 F.Supp.2d 442, 449-50 (D. Del. 2009).

258. Of course, court rulings can also be cited rejecting the statutory claims outlined in this section. See, e.g., Ecology Ctr. v. Castaneda, 574 F.3d 652, 663-64, 666-68 (9th Cir. 2009); Wild Earth Guardians v. U.S. Forest Serv., 120 F.Supp.3d 1237, 1258-76 (D. Wyo. 2015). These random decisions, however, do not contradict the basic point that the judiciary is playing an important role in promoting and legitimizing the movement toward landscapescale conservation to accomplish nature conservation goals.

259. See generally Symposium, Biodiversity and Its Effects on Private Property, 38 IDAHO L. Rev. 291 (2002). 
alded land ethic, which rests upon the notion that everything in nature is connected and posits that land owners owe a moral duty to the wider community to use their property in a manner that advances the public interest as well as their own private interests. ${ }^{260}$ From this perspective, property is not viewed merely in economic terms as a commodity; rather, land ownership entails public responsibilities that can — and often should—surpass the autonomous individual rights that traditionally have attached to ownership. ${ }^{261}$ This profound ethical notion has taken hold in several quarters and helps account for the government's willingness to offer incentives to encourage conservation behavior on the part of landowners. Thus, federal and state laws now employ several related legal devices-acquisition, incentives, subsidies, and regulatory constraints-to promote nature conservation on private lands. These laws create the opportunity to conjoin public and private conservation efforts through coordinated, landscape-scale planning efforts geared toward protecting wildlife habitat, limiting fragmentation, and promoting ecological resilience.

The federal government is actively engaged in acquiring select private lands to advance its nature conservation goals. ${ }^{262}$ Under the Land and Water Conservation Act of $1965,{ }^{263}$ the federal land management agencies receive revenues derived from off-shore oil and gas leasing to purchase private lands for conservation and recreational purposes. Although Congress has rarely appropriated the full amount of the funds received from off-shore lease sales, the federal agencies have nonetheless acquired nearly 5 million acres since 1964, ${ }^{264}$ often purchasing private inholdings within national parks and wilderness areas as well as adjacent properties in sensitive locations in order to limit inconsistent uses

260. Aldo Leopold, A Sand County Almanac with Other Essays on Conservation FROM Round River, 217-41 (1966). For additional insights on Leopold's legacy and views, see Eric T. Freyfogle, Why Conservation Is Failing and How It Can Regain Ground 14-51 (2017); Eric T. Freyfogle, The Land Ethic and Pilgrim Leopold, 61 U. Colo. L. Rev. 217 (1990).

261. See Eric T. Freyfogle, Bounded People, Boundless Lands 102-08 (1998); Henry Diamond \& Patrick Noonan, Land Use in America 4-6, 79-84 (1996); Carol M. Rose, Property Rights and Responsibilities, in Thinking Ecologically: The NeXt Generation of EnVironmental Policy 49, 49-59 (1997).

262. James R. Rasband \& Megan A. Garrett, A New Era in Public Land Policy? The Shift Toward Reacquisition of Land and Natural Resources, 53 Rocky MTN. Min. L. INST. \$11.011 (2007).

263. 16 U.S.C. $\S$ 4601-4 to 4601-11 (1965); 54 U.S.C. $§ 200306$ (2012). See generally MaRgaret Walls, Res. for the Future, Federal Funding for Conservation and Recreation: The Land and Water Conservation Fund (2009), https://perma.cc/ X98U-5BKX; Carol Hardy Vincent, Cong. Research Serv., Land and Water Conservation Fund: Overview, Funding History, and Current Issues (2006); Jeffrey Zinn, Cong. Research Serv., Land and Water Conservation Fund: Current Status and Issues (2005).

264. Coggins ET AL., supra note 82, at 402. 
that could degrade existing protected lands. ${ }^{265}$ An assortment of other federal programs, including the North American Wetlands Conservation Act, the Cooperative Endangered Species Conservation Fund, and the Forest Legacy Program, also provide funds to acquire private lands for conservation purposes or to offer technical assistance to landowners interested in managing their lands for environmental goals. ${ }^{266}$ When these federal funds have not been immediately available, the agencies have partnered with land trusts and other conservation organizations, which will either purchase the identified lands outright or acquire a conservation easement, often with the understanding that the United States will eventually buy the acquired interest once it obtains the necessary funds. ${ }^{267}$ In addition, under FLPMA, ${ }^{268}$ the agencies have authority to exchange lands with states and private landowners to protect conservation values, though it has often proven difficult to meet the statutory equal valuation requirements. ${ }^{269}$ But Congress has legislatively approved several large federal-state land exchanges, like the Utah Schools and Land Exchange Act of $1998,{ }^{270}$ which

265. See, e.g., Robinson Meyer, The Private Islands Inside National Parks, The AtLantic (Sept. 17, 2015), https://perma.cc/AG84-QXCJ; Jim Carlton, Land Rush at National Parks, WALL ST. J. (Jul. 22, 2012), https://perma.cc/74QY-LSZ9.

266. See Rasband \& Garrett, supra note 262, at 11.06; see also Barton H. Thompson Jr., Providing Biodiversity through Policy Diversity, 38 Idaho L. Rev. 355, 365-79 (2002).

267. See infra notes 341-44 and accompanying text (describing TNC's role in acquiring ranchland in Colorado's San Luis Valley and then transferring ownership to the National Park Service).

268. 43 U.S.C. $§ 1716$ (2012); Nat'l Parks Conservation Ass'n v. Bureau of Land Mgmt., 606 F.3d 1058, 1080 (9th Cir. 2010); Desert Citizens Against Pollution v. Bisson, 231 F.3d 1172, 1175 (9th Cir. 2000). See generally Bill Paul, Statutory Land Exchanges That Reflect "Appropriate" Value and "Well Serve" The Public Interest, 27 Pub. Land \& Resources L. REV. 107, 112-13 (2006).

269. In 1988, to streamline the FLPMA exchange process, Congress enacted 102 Stat. 1086, the Federal Land Exchange Facilitation Act, but irregularities in numerous appraisals have limited agency-driven exchanges in recent years. See generally Murray D. Feldman, The New Public Land Exchanges: Trading Development Rights in One Area for Public Resources in Another, 43 Rocky MTN. Min. L. InSt. 2 (1997). In 2000, to avoid these exchange problems, Congress adopted the Federal Land Transaction Facilitation Act, 43 U.S.C. §§ 2301-2306, effectively enabling the land management agencies to acquire environmentally sensitive lands by selling federally owned parcels situated near fast growing western cities, but the Act has now expired and with it the conservation acquisition opportunities it presented. The Act was modeled after the Southern Nevada Land Management Act of 1988, Pub. L. No. 105-263, 112 Stat. 2343, which Congress described as "[a]n act to provide for the orderly disposal of certain Federal lands in Clark County, Nevada, and to provide for the acquisition of environmentally sensitive lands in the State of Nevada." Southern Nevada Land Management Act of 1988, Pub. L. No. 105-263, 112 Stat. 2343 (1988).

270. Utah Schools and Land Exchange Act, Pub. L. No. 105-335, 112 Stat. 3139 (1998). Under this 1998 legislation, the state exchanged school trust land inholdings in several national parks, national monuments, recreation areas, forests, and Indian reservations for mineral-rich federal lands elsewhere and an additional $\$ 50$ million payment for the state's public schools. 
have broadly enhanced conservation values and recreational opportunities on the public lands.

Several states have established dedicated funding sources to purchase private lands or easements for conservation purposes. In 1992, Colorado created Great Outdoors Colorado ("GOCO") through funds derived from the state's lottery to "protect and enhance the state's wildlife, park, river, trail and open space heritage." ${ }^{271}$ Since its inception, GOCO has expended more than $\$ 960$ million and protected, through fee simple purchases or conservation easements, more than 1 million acres; its current strategic plan expressly focuses on protecting large, connected landscapes. ${ }^{272}$ Using revenues from its mineral taxes, Wyoming established the Wyoming Wildlife and Natural Resources Trust in 2006 with the mission of acquiring and restoring wildlife habitat across the state. ${ }^{273}$ But federal and state governments face an array of competing demands for their public revenues, so these funds cannot be consistently relied upon to address today's myriad conservation issues.

Given this reality, the nonprofit land trust movement has assumed a major role in protecting conservation values on private lands through fee simple purchases as well as voluntary conservation easements restricting future development and incompatible uses on the land. Not only does the law of property in all fifty states explicitly provide for perpetual conservation easements, ${ }^{274}$ but federal law also promotes the use of conservation easements through significant tax credits. ${ }^{275}$ The Internal Revenue Code grants landowners who donate a conservation easement to a land trust or governmental agency a limited charitable deduction on their income tax. ${ }^{276}$ To qualify for the deduction, the donated easement must be permanent, ${ }^{277}$ and it must serve one of several enumerated purposes, such as preserving land for outdoor recreation, protecting natural

271. The GOCO program was established through a 1992 ballot initiative that amended the state constitution and authorized the use of state lottery funds for specified conservation purposes. See Colo. State Const., art. XXVII.

272. Finances, Great Outdoors Colo., https://perma.cc/XV4B-QCWQ (noting more than $\$ 960$ million spent on conservation projects); see Strategic Plan, Great Outdoors Colo., https://perma.cc/72MU-FM7F; see also About Us, GrEat Outdoors Colo., https://per ma.cc/58DL-XKVG (noting more than one million acres protected).

273. Wyo. Stat. Ann. §§ 9-15-101 to -107 (2016). The trust has already expended nearly $\$ 58$ million, part of which has gone to acquire strategic conservation easements. See WYO. WildLife \& Nat. Res. Tr., https://perma.cc/94LX-ZYWS.

274. John G. Sprankling \& Raymond R. Coletta, Property: A Contemporary ApPROACH 715 (2015).

275. C. Timothy Lindstrom, Income Tax Aspects of Conservation Easements, 5 Wyo. L. REv. 1, 3 (2005); Nancy McLaughlin, Increasing the Tax Incentives for Conservation Easement Donations: A Responsible Approach, 31 Ecology L.Q. 1, 28-29 (2004).

276. 26 U.S.C. $\S 170(\mathrm{~b})(1)(\mathrm{E})(\mathrm{i})$ (2012). The deduction is limited to the value of the donation, and further limited to fifty percent of the donor's annual income with a 15 -year carry-forward period. $I d$. $\S 170(\mathrm{~b})(1)(\mathrm{E})(\mathrm{i})-(\mathrm{ii})$.

277. 26 U.S.C. $§ 170(h)(5)(2012)$; see McLaughlin, Conservation Easements, supra note 159. 
habitat for fish and wildlife, or preserving open space for the general public's scenic enjoyment. ${ }^{278}$ Moreover, conservation easement donors can receive a federal estate tax benefit, removing the value of the easement from the landowner's estate for federal tax purposes. ${ }^{279}$ Several states also grant income tax credits to property owners who donate a qualified conservation easement, ${ }^{280}$ and the encumbered property may qualify for a reduced property tax assessment too. ${ }^{281} \mathrm{By}$ most accounts, these federal and state tax incentives have contributed directly to the extraordinary growth of the land trust movement and the use of conservation easements as an important nature preservation strategy.

Beyond these voluntary transactional strategies, governmental regulation represents another important legal tool for promoting nature conservation on private lands. Although federal regulation of land use is quite controversial, several federal laws impose rigorous, ecologically-protective regulatory requirements on private landowners. Section 9 of the ESA, by prohibiting anyone from "taking" a federally protected species, effectively requires private landowners, whenever such a species is present, to protect its critical habitat, thus potentially limiting the development or use of the affected lands. ${ }^{282}$ However, landowners can relieve themselves of Section 9 liability by preparing a federally approved habitat conservation plan ("HCP") and then using their land consistent with the plan. ${ }^{283}$ By 2016, the federal government had approved $682 \mathrm{HCPs}$ covering millions of acres and protecting more than 1448 animal species and 944 plant species. ${ }^{284}$ In recent years, HCPs are being designed as expansive multi-species, landscape-level conservation plans, as reflected in the Plum Creek Timber Company's Native Fish Habitat Conservation Plan that extends

278. 26 U.S.C. $\S 170(\mathrm{~h})(4)(2012)$.

279. 26 U.S.C. $\S 2055(\mathrm{f})(2012)$.

280. See, e.g., Colo. Rev. Stat. § 39-22-522 (2017); Wash. Rev. Code Ann. § 11.98 .070 (West 2015).

281. In most instances, an easement will limit the uses to which the encumbered property may be put, thus reducing its market valuation for property tax assessment purposes. See, e.g., Colo. Rev. Stat. § 38-30.5-109 (2017); see also Robert H. Levin, Land Tr. All., A Guided Tour of the Conservation Easement Enabling Statutes 44 (2014), https://perma .cc/4JJB-ZDEB (explaining the tax implications of conservation easements).

282. 16 U.S.C. § 1538(a)(1)(B) (2012); Babbitt v. Sweet Home Chapter, 515 U.S. 687, 687 (1995).

283. 16 U.S.C. §1539(a)(1)(B) (2012); 50 C.F.R. § 17.32(b) (2016); see Karin P. Sheldon, Habitat Conservation Planning: Addressing the Achilles Heel of the Endangered Species Act, 6 N.Y.U. ENVTL. L.J. 295 (1998).

284. ECOS Habitat Conservation Plans, U.S. Fish \& Wildlife Serv., https://perma.cc/ MB4M-E2S4. By late 2017, 670 HCPs had been approved. Most of the earlier HCPs involved planning areas of less than 1000 acres. The HCPs now exceed 500,000 acres, and several are larger than 1,000,000 acres. Endangered Species Permit Facts Sheet: Habitat Conservation Plans, U.S. FISH \& WILdlife SERV., https://perma.cc/QZ2Y-8FBX. 
across three states and covers 1.6 million acres. ${ }^{285}$ Even when species are not "listed" under the ESA, the FWS has engaged states and private landowners in Candidate Conservation Agreements ("CCAs"), ${ }^{286}$ as exemplified by the vast sage grouse initiative that represents an unprecedented landscape conservation effort stretching across eleven states and 165 million acres of public and privately-owned land. ${ }^{287}$

The Clean Water Act extends federal legal protection to ecologically critical wetlands, ${ }^{288}$ many of which are found on private lands. Wetlands are particularly important for conservation purposes in the arid West where the early settlers claimed the lower elevation river valleys and nearby riparian areas, which provide key wildlife habitat and vital connective corridors. Section 404 of the Clean Water Act regulates development opportunities for landowners in wetland areas, who can obtain a dredge and fill permit by adopting acceptable mitigation measures designed to protect, restore, or replace the affected wetlands. ${ }^{289}$ Although neither the ESA nor the Clean Water Act extend permanent protection to private lands, these federal laws nonetheless promote private nature conservation efforts that can be linked to similar efforts on nearby public lands.

An assortment of state laws, including zoning, open space, and, in some states, endangered species laws, also regulate private land uses and can be employed to advance nature conservation goals on private lands. ${ }^{290}$ One prominent

285. Plum Creek Timber Company, Native Fish Habitat Conservation Plan, U.S. FISH \& WILDLIFE SERV. (2000), https://perma.cc/9ZQG-RQ4M.

286. 50 C.F.R. $§ 17.32$ (d) (2016). See Defs. of Wildlife v. Jewell, 70 F.Supp.3d 183, 186 (D.D.C. 2014), aff d sub nom, Defs. of Wildlife \& Ctr. for Biological Diversity v. Jewell, 815 F.3d 1, 6 (D.C. Cir. 2016) (finding that the CCAs and CCAAs in place effectively eliminated threats to the lizard species previously proposed for listing under the ESA).

287. Bureau of Land Mgmt., Sage Grouse and Sage-Brush Conservation (2015), https://perma.cc/WQM5-MB4L. Although the Trump Administration has revisited the Obama Administration's sage grouse conservation strategy, the recommended changes do not anticipate altering the landscape-level approach to this conservation effort; rather, the recommendations are to provide the states with additional flexibility in shaping their conservation strategies. Sec'y of the Interior, Order No. 3353 (June 7, 2017); Report in Response to Secretarial Order 3353 (Aug. 4, 2017).

288. 33 U.S.C. §1341(a) (2012) (prohibiting the discharge of any pollutant); § 1362(6) (2012) (defining "pollutant" to include dredge and fill material); § 1344(a), (d) (2012) (authorizing the Army Corps of Engineers to issue permits for the discharge of dredge or fill materials); see Rapanos v. United States, 547 U.S. 715, 722-24 (2006) (describing the interplay between these Clean Water Act statutory provisions). See generally James Salzman et al., Protecting Ecosystem Services: Science, Economics, and Law, 20 Stan. EnvTL. L.J. 309 (2001).

289. 40 C.F.R. $§ 230$ (2016); see Royal C. Gardner et al., Compensating for Wetland Losses Under the Clean Water Act (Redux): Evaluating Federal Compensatory Mitigation Regulation, 38 Stetson L. Rev. 213 (2009); Michael Keller, Look Before You Fill! Dredge and Fill Permitting Under \$ 404 of the Clean Water Act, 17 UTAH B.J. 26 (2004).

290. See James M. McElfish Jr., Nature Friendly Ordinances 23-26, 31-32 (2004); James D. Brown, Biophilic Laws: Planning for Cities with Nature, 34 VA. EnVTL. L.J. 52 
example is California's Natural Community Conservation Planning Act, ${ }^{291}$ which takes a broad, proactive approach to species conservation by promoting landscape-scale planning, including new nature reserve designations and adaptive management requirements, on both public and private lands to avoid endangered species listings. Alternatively, fact-based local land use plans are being developed in some states and can be used to identify common nature conservation goals and to collaborate with federal land managers. ${ }^{292}$

To be sure, the foregoing recitation of federal and state laws available to promote nature conservation goals among private landowners covers only part of the legal landscape. Other laws, like the Fifth Amendment's prohibition against the governmental taking of property without just compensation, provide substantial legal protection to private landowners that can enable them to resist public conservation initiatives. ${ }^{293}$ The important point, however, is that the law does selectively facilitate nature conservation on private lands where the owner is motivated to do so or where endangered species or other important conservation values are at stake. Consequently, these federal and state laws present an additional opportunity to promote ecosystem-scale planning and management with an eye toward knitting public and private lands together to advance national nature conservation efforts directed toward protecting ecological resources and processes.

\section{Constructing a Landscape Conservation Network}

The convergence of the science and law underlying nature conservation on the public lands has given rise to numerous large-scale conservation initiatives, ${ }^{294}$ especially on the western public lands. An abbreviated inventory reveals an impressive assortment of protected complexes extending across jurisdictional

(2016); see, e.g., Griepenburg v. Twp. of Ocean, 105 A.3d 1082, 1083 (2015) (finding town zoning ordinances designating an environmental conservation district valid).

291. See Cal. Fish \& Game Code 2800-2840 (West 2016); see also Craig Manson, Natural Communities Conservation Planning: California's New Ecosystem Approach to Biodiversity, 24 ENVTL. L. 603 (1994).

292. See Michelle Bryan, Cause for Rebellion?: Examining How Federal Land Management Agencies and Local Governments Collaborate on Land Use Planning, 6 J. Energy \& EnvTL. L. 1 (2015).

293. See, e.g., Lucas v. S.C. Coastal Council, 505 U.S. 1003 (1992); Joseph L. Sax, Property Rights and the Economy of Nature: Understanding Lucas v. South Carolina Coastal Council, 45 STAN. L. Rev. 1433 (1993).

294. See generally Matthew McKinney et al., Regionalism in the West: An Inventory and Assessment, 23 Pub. Land \& Resources L. Rev. 101 (2002). See also David M. Theobald et al., Connecting Natural Landscapes Using a Landscape Permeability Model to Prioritize Conservation Activities in the United States, 5 Conservation Letters 123, 127 (2012) (arguing that the interior portions of the West are "among the most connected natural landscapes in the United States"). 
boundaries. How this has come to pass differs from place to place, as does the level of protection provided. This ad hoc approach to landscape-scale conservation, however, does not ensure any level of formal coordination among the responsible agencies, nor does it provide federal land managers with clear incentives to expand existing conservation efforts by protecting connective corridors or restoring degraded ecosystems. To address these shortcomings, Congress should adopt a new landscape conservation network law that would legitimize what is occurring on the ground and promote a more coordinated and connected approach to these farsighted nature conservation efforts.

\section{A. De Facto Landscape Conservation: The Current Ad Hoc Approach}

It would be elegant and tidy were it possible to lump together the nation's diverse de facto nature conservation complexes, both in terms of their origins and protections, but that is plainly not the case. The underlying political and legal origins of these areas are quite different in most cases, and that is also true for the level of protection that each enjoys. The common theme, however, is that each protected land complex extends across jurisdictional boundaries to safeguard important wildlife species and ecological processes as well as scenic settings and recreational opportunities. ${ }^{295}$ The ecosystem concept provides something like a general organizing principle, often with a major national park or other substantial protected area at the core. ${ }^{296}$ Several examples follow with a brief description of the origins and type of protection for each. This sampling of cross-boundary protected complexes is illustrative of what is happening on the landscape, even in the absence of more formal arrangements or a comprehensive plan.

\section{Greater Yellowstone Ecosystem}

When one imagines a large protected landscape dedicated primarily to nature, the Greater Yellowstone Ecosystem ("GYE") comes immediately to mind. Containing two world-renowned national parks, seven national forests, two national wildlife refuges, several large wilderness areas, and an array of charismatic wildlife species, ${ }^{297}$ the roughly 20 -million-acre GYE rose to prominence during the 1980s when a congressional committee determined that the area's iconic grizzly bear population was in steep decline and called for more coordinated management to protect against the bear's demise. ${ }^{298}$ Conservation groups seized

295. McKinney et al., supra note 294, at 102.

296. Keiter, To Conserve Unimpaired, supra note 28, at 203-30.

297. For an overview of the GYE and its extraordinary wildlife resources, see David Quammen, Yellowstone: America's Wild Idea, 229 Nat'L Geographic 54 (May 2016).

298. See Greater Yellowstone Ecosystem: Oversight Hearing Before the Subcomm. on Public Lands and the Subcomm. on National Parks, House Comm. on Interior and Insular Affairs, 99th Cong., 
upon grizzly bear habitats to define the GYE, while the responsible federal and state agencies, faced with recovering the bear population under the ESA, formed an interagency grizzly bear committee to oversee the recovery effort. ${ }^{299}$ At the same time, the Greater Yellowstone Coordinating Committee launched a federal interagency vision process designed to promote more coordinated management across the ecosystem, ${ }^{300}$ but it ultimately failed to produce a meaningful plan. ${ }^{301}$ This left the Park Service, Forest Service, and the FWS to pursue their respective missions without any formal commitment to a common conservation agenda other than collaborating to recover the bear.

The GYE, with more than 6.5 million acres in designated national park, wilderness, or refuge lands, already enjoyed substantial legal protection, which has plainly abetted nature conservation efforts over the ensuing years. Driven in large part by the grizzly bear recovery effort, the region has seen a marked

94-103 (1985); Cong. Research Serv., Greater Yellowstone Ecosystem: An Analysis of Data Submitted by Federal and State Agencies 19, 177-79 (1986); Paul Schullery, Searching for Yellowstone: Ecology and Wonder in the Last Wilderness 197-207 (1997). See generally Robert B. Keiter \& Mark S. Boyce, Greater Yellowstone's Future: Ecosystem Management in a Wilderness Environment, in THE Greater Yellowstone Ecosystem: Redefining America's Wilderness Heritage 392-95 (Robert B. Keiter \& Mark S. Boyce eds., 1991); Susan G. Clark, Ensuring Greater Yellowstone's Future: Choices for Leaders and Citizens 123-26 (2008).

299. See Interagency Grizzly Bear Comm., https://perma.cc/QMQ6-XSFN. For a comprehensive overview of the Yellowstone grizzly bear population, including reproductive rates, mortality threats, habitat needs, and management options, see FrANK C. CRAIGHEAD, JR., et al., The Grizzly Bears of Yellowstone: Their Ecology in the Greater Yellowstone Ecosystem (1995); see also Brian L. Kuehl, Conservation Obligations under the Endangered Species Act: A Case Study of the Yellowstone Grizzly Bear, 64 U. CoLO. L. Rev. 607, 613-18 (1993) (summarizing the threats to the Yellowstone grizzly bear population).

300. The so-called "Vision" exercise was overseen by the Greater Yellowstone Coordinating Committee ("GYCC"), which consisted of Yellowstone area federal land managers who had been formally meeting together since the 1960s as the GYCC. Most observers, however, were and remain critical of the GYCC as unable to reach or implement meaningful ecosystem-scale resource management decisions. CLARK, supra note 298, at 29-65; Ronald D. Brunner \& Tim W. Clark, A Practice Based Approach to Ecosystem Management, 11 ConserVATION Biology 48, 49 (1997).

301. See Greater Yellowstone Coordinating Comm., Nat'l Park Serv. \& U.S. Forest Serv., Visions for the Future: A Framework for Coordination in the Greater Yellowstone Area (1990); Greater Yellowstone Coordinating Comm., Nat'l Park Serv. \& U.S. Forest Serv., A Framework for Coordination in the Greater Yellowstone Area (1991). For an analysis of this ecosystem coordination effort, see Bruce Goldstein, Can Ecosystem Management Turn an Administrative Patchwork into a Greater Yellowstone Ecosystem?, 8 Nw. ENVTL. J. 285 (1992); Pamela Lichtman \& Tim W. Clark, Rethinking the "Vision" Exercise in the Greater Yellowstone Ecosystem, 7 Soc'y \& Nat. Resources 459 (1994); John Freemuth \& R. McGreggor Cawley, Science, Expertise and the Public: The Politics of Ecosystem Management in the Greater Yellowstone Ecosystem, 40 Landscape \& Urban Plan. 211, 212-17 (1998). 
decline in timber harvesting, new roads, mineral development, and livestock grazing on the area's multiple-use federal lands. ${ }^{302}$ Congress has added new protections to the area by designating two wild and scenic river segments in Wyoming, ${ }^{303}$ by approving a major land exchange on the Gallatin National Forest, ${ }^{304}$ and by authorizing a buyout of mineral leases in the Wyoming Range on the Bridger-Teton National Forest. ${ }^{305}$ At the agency level, the Forest Service has dramatically altered its regional priorities in its second generation forest plans to emphasize wildlife and recreational values, ${ }^{306}$ the FWS has restored wolves to the area, ${ }^{307}$ and Yellowstone's bison have gained access to important winter habitat outside the park boundary. ${ }^{308}$ Further, the Park Service, Forest Service, the BLM, state of Wyoming, and several private landowners have collaborated to establish the Path of the Pronghorn migration corridor that facilitates the 150-mile seasonal antelope migration between Grand Teton National Park and southerly, lower elevation lands in Wyoming's Red Desert. ${ }^{309}$

Despite these conservation achievements and the GYE's international renown as a wildlife stronghold, the region faces several ongoing challenges. The FWS's recent decision removing the Yellowstone grizzly bear population from

302. Shafer, supra note 35, at 270; ScHULLERY, supra note 298, at 210-16. Perhaps most notably, the proposed New World Mine on Yellowstone National Park's northeastern flank was blocked following presidential intervention in the controversy. See William J. Lockhart, External Threats to Our National Parks: An Argument for Substantive Protection, 16 STAN. ENVTL. L.J. 3, 5-11 (1997).

303. 16 U.S.C. § 1276(a)(33) (2012) (Clarks Fork); id. § 1276(a)(50) (Snake River).

304. Gallatin Range Consolidation and Protection Act of 1993, Pub. L. No. 103-91, 107 Stat. 987 (1993); Gallatin Land Consolidation Act of 1998, Pub. L. No. 105-267, 112 Stat. 2371 (1998).

305. Wyoming Range Legacy Act, Omnibus Public Land Management Act of 2009, Pub. L. No. 111-11, 123 Stat. 1991, § 3201 (2009); Jeff Gearino, A 'Green’ Victory: Wyoming Range Gains Protection from Further Energy Development, CASPER STAR TRIB., (Dec. 29, 2009), https:// perma.cc/52NQ-YBBX.

306. See, e.g., U.S. Forest Serv., Bridger-Teton National Forest Land and Resource Management Plan 140-45 (2015), https://perma.cc/5T3E-UGAH; U.S. Forest Serv., Shoshone National Forest Land management Plan 2015 Revision 9-22 (2015).

307. See U.S. Fish \& Wildlife Serv., The Reintroduction of Gray Wolves to Yellowstone National Park and Central Idaho: Final Environmental Impact Statement iii (1994); Hank Fischer, Wolf Wars (1995); Thomas McNamee, The Return of the Wolf to Yellowstone 92-95, 216, 315-23 (1998).

308. Bison Ecology, Nat'L Park Serv. (Oct. 5, 2017), https://perma.cc/H3FX-B8BX. See generally Bison Management, NAT'L Park Serv. (Nov. 30, 2017), https://perma.cc/25KM8WZV; Ronald D. Brunner et al., Finding Common Ground: Governance and Natural Resources in the American West (2002).

309. See David N. Cherney, Securing the Free Movement of Wildlife: Lessons from the American West's Longest Land Mammal Migration, 41 EnvTL. L. 599 (2011); Joel Burger et al., Optimism and Challenge for Science-Based Conservation of Migratory Species in and out of U.S. National Parks, 28 Conservation Biology 4, 9 (2014); P.J. White et al., Partial Migration and Philopatry of Yellowstone Pronghorn, 135 Biological Conservation 502 (2007). 
the federal endangered species list eliminates a key legal mandate that has compelled the federal and state agencies to work cooperatively on an ecosystem basis to restore the bear population. ${ }^{310}$ Ongoing subdivision and private land development continues to fragment portions of the GYE with noticeable adverse impacts on wildlife habitat and movement patterns. ${ }^{311}$ The Pinedale Anticline oil field in the region's southern reaches ${ }^{312}$ and the potash mining complex in southeastern Idaho's Caribou National Forest have industrialized these areas with adverse effects on area fish and wildlife. ${ }^{313}$ Yet, despite the absence of formal legal recognition, the GYE concept has achieved legitimacy on the landscape, and myriad efforts continue throughout the region to protect its natural values.

\section{Crown of the Continent Ecosystem}

To the north, the Crown of the Continent Ecosystem concept has taken hold with Glacier and Waterton national parks at its core along with Montana's expansive Bob Marshall wilderness complex. Extending across the U.S.-Canadian border, the Crown Ecosystem covers roughly 18 million acres in northwestern Montana, southwestern Alberta, and southeastern British Columbia. It includes the two national parks, the Flathead and the Lewis \& Clark national forests, three major wilderness areas, portions of the Blackfeet Indian Reservation, and several Wild and Scenic River segments on the Flathead River system that sustains Flathead Lake in western Montana. ${ }^{314}$ This remote area is home to

310. U.S. Fish \& Wildlife Serv., Endangered and Threatened Wildlife and Plants; Removing the Greater Yellowstone Ecosystem Population of Grizzly Bears From the Federal List of Endangered and Threatened Wildlife, 82 Fed. Reg. 30,502 (June 30, 2017) (to be codified at 50 C.F.R. pt. 17); see Grizzly Bears \& the Endangered Species Act, NAT'L ParK SerV., https:/ /perma.cc/R2ZW-AMKF.

311. Shafer, supra note 35, at 257-58, 270; Patricia H. Gude et al., Biodiversity Consequences of Alternative Future Land Use Scenarios in Greater Yellowstone, 17 Ecological ApPlicATiOns 1004 (2007); Patricia H. Gude et al., Rates and Drivers of Rural Residential Development in the Greater Yellowstone, 77 Landscape \& URban Plan. 131 (2006).

312. Bureau of Land Mgmt., Final Supplemental Environmental Impact Statement, Pinedale Anticline Oil and Gas Exploration and Development ProJECT (2008), https://perma.cc/4E7J-22ZV. Theodore Roosevelt Conservation P'ship v. Salazar, 661 F.3d 66 (D.C. Cir. 2011); W. Watersheds Project v. Salazar, No. 4:08-CV516-BLW, 2012 WL 5880658 (D. Idaho Nov. 20, 2012).

313. Greater Yellowstone Coal. v. Larson, 641 F. Supp. 2d 1120, 1141 (D. Idaho 2009), aff d sub nom. Greater Yellowstone Coal. v. Lewis, 628 F.3d 1143 (9th Cir. 2010), as amended (Jan. 25, 2011).

314. See Ben Long, The Crown of the Continent Ecosystem: Profile of a Treasured Landscape, in Sustaining Rocky Mountain Landscapes 17, 28-33 (Tony Prato \& Dan Fagre eds., 2007); Lara D. Guercio \& Timothy P. Duane, Grizzly Bears, Gray Wolves, and Federalism, Ob My! The Role of the Endangered Species Act in De Facto Ecosystem-Based Management in the Greater Glacier Region of Northwest Montana, 24 J. EnVTL. L. \& LiTIG. 285, 299 (2009); 
grizzly bears, wolves, elk, and other charismatic wildlife species, testifying to its general wilderness-like character. That said, the region has endured considerable conflict over open pit mining, timber harvesting, oil and gas drilling, road construction, and motorized recreation, while the social-economic profile of the region surrounding Glacier National Park is changing as newcomers are attracted to the area's beauty and recreational opportunities. ${ }^{315}$

Significant efforts are afoot to preserve the Crown region's natural attributes and character. Following several high-profile cross-border confrontations over proposed mining activity in the Canadian North Fork area, the principal land managers on both sides of the border have come together as the Crown Managers Partnership, ${ }^{316}$ acknowledging the unique landscape that they share and looking for opportunities to better coordinate management across jurisdictional boundaries. Meantime, the Flathead and the Lewis \& Clark national forests have ramped down timber harvesting, seen the sensitive North Fork and Rocky Mountain Front areas withdrawn from mining and mineral leasing, and adopted travel management plans aimed at limiting motorized recreational activity. ${ }^{317}$ In 2014, Congress established a new 195,000 acre Rocky Mountain Front Conservation Management Area along with several new wilderness additions adjacent to the Bob Marshall wilderness complex, ${ }^{318}$ further acknowledging the conservation values attached to this rugged area. After intense negotiations between the state of Montana and British Columbia, the province agreed to forego development in the Canadian North Fork country, ${ }^{319}$ while Congress, through the North Fork Watershed Protection Act of 2014, ${ }^{320}$ withdrew 362,000 acres of Flathead National Forest lands abutting the North Fork of the Flathead River from any future mining or energy exploration activity to protect water quality and the area's natural values. The net result is an expansive

Dena Pedynowski, Prospects for Ecosystem Management in the Crown of the Continent Ecosystem, Canada-United States: Survey and Recommendations, 17 Conservation Biology 1261, 1262 (2003); see also UM Crown of the Continent and Greater YellowSTONE INITIATIVE, https://perma.cc/8JU8-JGKZ (providing a periodic overview of developments in the Crown of the Continent ecosystem).

315. See Joseph L. Sax \& Robert B. Keiter, The Realities of Regional Resource Management: Glacier National Park and Its Neighbors Revisited, 33 Ecology L.Q. 233 (2006); Joseph L. Sax \& Robert B. Keiter, Glacier National Park and Its Neighbors: A Study of Federal Interagency Relations, 14 Ecology L.Q. 207 (1987).

316. Sax \& Keiter, Realities, supra note 315, at 302-04. For current information about the Crown Managers Partnership, see Vision Statement: Managing Together for Ecological Integrity at a Large Landscape Scale, Crown Managers P'ship (2011), https://perma.cc/Q9TM-P5LW.

317. Sax \& Keiter, Realities, supra note 315 , at 246-58, 267-85.

318. Pub. L. No. 113-291, § 3065, 128 Stat. 3833 (2014) (codified at 16 U.S.C. § 539r (2012)).

319. Jack Tuholske \& Mark Foster, Solving Transboundary Pollution Disputes Locally: Success in the Crown of the Continent, 92 Or. L. Rev. 649 (2014).

320. Pub. L. No. 113-291, 128 Stat. 3292 (2014). 
array of public lands on both sides of the border where nature conservation has assumed a priority position. ${ }^{321}$

\section{The California Desert Area}

A ten-million-acre conglomeration of protected public lands has emerged in California's Mojave Desert, attributable to a combination of congressional legislation, presidential edict, and private philanthropic efforts. In the 1976 FLPMA, with Death Valley and Joshua Tree national monuments already on the books, Congress designated the California Desert Conservation Area, finding that "the California desert environment is a total ecosystem that is extremely fragile, easily scarred, and slowly healed" and calling on the BLM to manage the area for "multiple use and sustained yield, and the maintenance of environmental quality." 322 In 1994, Congress adopted the California Desert Protection Act, which converted Death Valley to a national park and added 1.2 million acres to it (making Death Valley at 3.4 million acres the largest national park in the continental U.S.), converted Joshua Tree to national park status and added 234,000 acres to it, established a new 1.6 million acre Mojave National Preserve, and designated 3.5 million acres of BLM-administered lands as wilderness areas. ${ }^{323}$ The area also contains six large military installations used for defense training purposes that remain largely undeveloped and thus offer potential conservation opportunities. ${ }^{324}$ In 2005 , to better coordinate management across this vast 20 -million-acre landscape, the various federal and state agencies responsible for the area created the Desert Managers Group, which has committed to conserving and restoring desert resources. ${ }^{325}$

Recently, executive-level actions have expanded the area's protected lands and promoted better coordinated planning. In late 2015, after Congress repeatedly failed to act on legislative proposals to further increase the region's pro-

321. This emergent commitment to wildland conservation, however, has not stopped the rapid decline of Glacier National Park's namesake glaciers-a result of the warming climate, which also speaks to the need for a landscape-level approach to conservation. See Myrna H.P. Hall \& Daniel B. Fagre, Modeled Climate-Induced Glacier Change in Glacier National Park, 1850-2100, 53 BioSci. 131, 131-32 (2003); Dan Fagre, Photo Evidence: Glacier National Park is Melting Away, NAT'L GeograPhic (Oct. 21, 2015), https://perma.cc/9AD7ANQF.

322. 43 U.S.C. § 1781(a)(2), (b) (2012).

323. 16 U.S.C. $\S \S 410$ aaa to $410 a a a-83$ (2012). See generally Frank Wheat, California DeSert Miracle: The Fight for Desert Parks and Wilderness (1999).

324. See Desert Managers Grp., Working Together to Conserve Our Desert Lands: FY06 Accomplishments Report \& FY07 Five Year Plan 2 (2007) https:// perma.cc/5VJ2-KE9H; see also supra notes 125-132 and accompanying text (providing additional information about conservation on military lands).

325. See Memorandum of Understanding to Participate in the Desert Managers Group (2005), https://perma.cc/GNB2-V7F2. 
tected areas, ${ }^{326}$ President Obama invoked the Antiquities Act to create three new national monuments: a 921,000-acre Mojave Trails National Monument that abuts the expansive Mojave National Preserve and links with several existing wilderness areas; a 135,000-acre Sand to Snow National Monument that protects critical wildlife corridors connecting the desert and alpine ecosystems; and the Castle Mountains National Monument, an area of 21,000 acres adjacent to the Mojave National Preserve. ${ }^{327}$ Still pending from the earlier congressional bill are proposals to designate 248,000 acres as BLM wilderness lands and to protect 74 miles as new Wild and Scenic River segments. ${ }^{328}$ Moreover, the federal land management agencies, working with California state agencies, have completed a comprehensive Desert Renewable Energy Conservation Plan designed to open less sensitive areas across the Mojave Desert to renewable energy projects, taking account of endangered species, wildlife corridors, and recreational concerns. ${ }^{329}$ And pursuant to a 2009 court decision, ${ }^{330}$ the BLM is completing a new off-highway vehicle plan that proposes to limit motorized recreational activity in deference to the region's sensitive environmental values. ${ }^{331}$ The region, which now boasts 10 million acres of protected lands, is a prime example of landscape-scale conservation on federal lands that seeks to balance preservation and environmentally sensitive development.

\section{Greater Grand Canyon Region}

The world renowned Grand Canyon National Park spans the Colorado River as it snakes through a striking southwestern desert landscape encompassing extensive federal and Indian lands. Over time, the park has been substan-

326. See, e.g., California Desert Protection Act of 2011, S. 138, 112th Cong. (2011); Forest Jobs and Recreation Act of 2011, S. 268, 112th Cong. (2011); Devil's Staircase Wilderness Act of 2011, H.R. 1413, 112th Cong. (2011).

327. Establishment of the Mojave Trails National Monument, 81 Fed. Reg. 8371 (Feb. 12, 2016); Establishment of the Sand to Snow National Monument, 81 Fed. Reg. 8379 (Feb. 12, 2016); Establishment of the Castle Mountains National Monument, 81 Fed. Reg. 8363 (Feb. 12, 2016); see Obama Strikes Again with Monuments; This Time in California, 41 Pub. Land News 1 (Feb. 19, 2016).

328. California Desert Protection and Recreation Act, S. 32, 115th Cong. (2017).

329. Bureau of Land Mgmt., Record of Decision for the Land Use Plan Amendment to the California Desert Conservation Plan, Bishop Resource Management Plan and Bakersfield Resource Management Plan (2016), https:/per ma.cc/DP9N-NCUY.

330. Ctr. for Biological Diversity v. Bureau of Land Mgmt., 746 F.Supp.2d 1055 (N.D. Cal. 2009); Ctr. for Biological Diversity v. Bureau of Land Mgmt., 2011 WL 337364 (N.D. Cal. Jan. 29, 2011) (remedy order).

331. Bureau of Land Mgmt., West Mojave Route Network Project Draft California Desert Conservation Plan Amendment and Supplemental Environmental Impact Statement for the California Desert District (2015), https://perma .cc/7EYH-EAFM. 
tially enlarged, first in 1919 when Congress transformed it from a presidentially decreed national monument to national park status, and then again in 1975 by the Grand Canyon Enlargement Act, ${ }^{332}$ which added nearly 400,000 more acres. Bisected by the Colorado River corridor, the park now encompasses 1.2 million acres and is bordered by two large national monuments. In 2000, President Clinton proclaimed the 1,048,325-acre Grand Canyon-Parashant National Monument on the park's northwestern flank and the 293,689-acre Vermillion Cliffs National Monument on the park's eastern extremity. ${ }^{333}$ Upriver in southern Utah lies the 1.25-million-acre Glen Canyon National Recreation Area abutted by the 1-million-acre Grand Staircase-Escalante National Monument, ${ }^{334}$ while the 1.5-million-acre Lake Mead National Recreation Area sits just downriver from the park. The Kaibab National Forest adjoins the park on the north, while the lightly populated Navajo, Hualapai, and Havasupai Indian reservations also flank the park. In short, much of the land abutting the park is either protected or mostly undeveloped, creating an expansive serpentine network along the Colorado River corridor where nature conservation largely prevails.

Although these various designations do not fully protect the area's natural values, other efforts have forestalled potentially damaging proposals and activities. In 2012, faced with a frenzy of uranium exploration on the park's flanks, Secretary of the Interior Salazar withdrew 1 million acres of public land from mining activity, ${ }^{335}$ a decision that has been judicially sustained. ${ }^{336}$ In 2005 , the

332. Pub. L. No. 93-620, 88 Stat 2089 (1975) (codified at 16 U.S.C. § 228a-j (2012)). See generally Michael F. Anderson, Polishing the Jewel: An Administrative History of Grand Canyon National Park (2000), https://perma.cc/23BZ-X26V.

333. Establishment of the Grand Canyon-Parashant National Monument, 65 Fed. Reg. 2825 (Jan. 11, 2000); Vermillion Cliffs National Monument, 65 Fed. Reg. 69,227 (Nov. 9, 2000).

334. Established in 1996 as a 1.7 -million-acre national monument following a congressionally authorized land exchange, the Grand Staircase-Escalante National Monument was reduced in size to nearly one million acres and reformulated as three separate smaller national monuments by President Trump in early December 2017. Presidential Proclamation No. 9682, Modifying the Grand Staircase-Escalante National Monument, 82 Fed. Reg. 58,089 (Dec. 4, 2017). The Trump boundary adjustments have mostly detached the original monument from Capitol Reef National Park, Bryce Canyon National Park, and Glen Canyon National Recreation Area, thus fragmenting what was a large, integrated landscape under the original 1996 monument proclamation. These recent boundary adjustments have been challenged in court. Associated Press, President Trump's National Monument Cuts Draw 5th Lawsuit, Wash. Post (Dec. 7, 2017), https://perma.cc/TX6X-AL6V.

335. Press Release, U.S. Dep't of the Interior, Secretary Salazar Announces Decision to Withdraw Public Lands near Grand Canyon from New Mining Claims, (Jan. 9, 2012), https:// perma.cc/FLV9-6DF6.

336. Yount v. Salazar, 2014 WL 4904423 (D. Ariz. Sept. 30, 2014); Yount v. Salazar, 933 F.Supp.2d 1215 (D. Ariz. 2013). Conservation groups and local Indian tribes pressed the Obama Administration for an expansive Greater Grand Canyon Heritage National Monument designation to permanently preclude mining on national forest and BLM lands near 
Grand Canyon Trust, a regional conservation organization, acquired 1200 acres of private ranchland along with grazing permits that extend across 900,000 acres of public land on the park's northern border. Since then, the Trust has been working with federal land managers to protect and restore the area's ecological values while running a scaled-down ranching operation. ${ }^{337}$ With concern mounting over the impact the upstream Glen Canyon Dam has on the Colorado River's ecology as it flows through the park, Congress was persuaded in 1992 to adopt the Grand Canyon Protection Act in an effort to restore more natural flows through the canyon. ${ }^{338}$ And fearful about water availability, the Forest Service recently denied permits to construct a small tourist city on the canyon's South Rim, keeping this still mostly natural area free from additional development. ${ }^{339}$ Though the park experiences poor air quality on many days as well as intrusive air tour overflights, and though a tramway proposal on Navajo lands could mar the river corridor, these concerns are also being addressed in an ongoing effort to protect the park and the surrounding landscape. ${ }^{340}$

\section{Colorado's San Luis Valley}

In southern Colorado's rural San Luis Valley, the Great Sand Dunes National Park and Preserve and three national wildlife refuges anchor a growing complex of protected public and private lands that extends across several million acres and embraces a diverse set of ecosystems. In 2000, with federal acquisition of the 97,000-acre Baca Ranch pending, Congress quadrupled the size of the Great Sand Dunes National Monument and upgraded it to national park and

the park, but the President chose not to make the designation. Grand Canyon Tr., Proposal Brief: The Greater Grand Canyon Heritage National Monument (2016), https://perma.cc/F6PL-C425.

337. Associated Press, Grand Canyon Trust Preserves Habitat, Grazing Land, Daily Herald (Sept. 30, 2005), https://perma.cc/4QP3-U36R; see Stewart v. Kempthorne, 554 F.3d 1245 (10th Cir. 2009); John D. Leshy \& Molly Mcusic, Where's the Beef: Facilitation Voluntary Retirement of Livestock Grazing from Federal Lands, 17 N.Y.U. EnVTL. L.J. 368 (2008).

338. Pub. L. No. 102-575, §§ 1801-09 (1992); see Robert W. Adler, Restoring ColoRado River Ecosystems: A Troubled Sense of Immensity 145-46 (2007); see also Michael Connor, Extracting the Monkey Wrench from Glen Canyon Dam: The Grand Canyon Protection Act: An Attempt at Balance, 15 Pub. Land L. Rev. 135, 136 (1994) (explaining that the Act directs the Secretary of the Interior to "operate Glen Canyon Dam ... in such a manner as to protect, mitigate adverse impacts to, and improve the values for which Grand Canyon National Park and Glen Canyon National Recreation Area were established") (quoting Pub. L. No. 102-575, § 1802(a) (1992)).

339. William Yardley, Federal Authorities Reject Plan for Development with 2200 Homes Near Grand Canyon, L.A. Times (Mar. 4, 2016), https://perma.cc/59K5-KHM9.

340. See Keiter, To Conserve Unimpaired, supra note 28, at 32-36; Bobby Magill, This Is Big: Giant Grand Canyon Polluter May Close, Adventure J. (Jan. 27, 2017), https://perma .cc/L24M-YG9V; Stopping Grand Canyon Escalade, Grand Canyon Tr. (2017), https:// perma.cc/NC8C-V9ED. 
preserve status, while also adding acreage to the nearby Rio Grande National Forest and establishing the 54,000-acre Baca National Wildlife Refuge. ${ }^{341}$ To facilitate creation of this adjoining array of federal protected areas, TNC originally purchased the Baca Ranch as part of a broader San Luis Valley conservation strategy and then held it awaiting congressional action to buy out the ranch. ${ }^{342}$ The nearby Monte Vista and Alamosa national wildlife refuges provide safe haven for migratory birds dependent on the valley's wetlands that are threatened due to water diversions and related agricultural activities. Other nearby national forest, BLM, and state lands contribute to the area's conservation acreage and value. These federal landholdings are complemented by TNC's neighboring 100,000-acre Medano-Zapata Ranch, the recently denominated 170,000-acre Sangre de Cristo Conservation Area, which includes the Trinchera and Blanca ranches now overlaid with TNC conservation easements, and other easement-protected ranchlands. ${ }^{343}$

These protective actions are helping to preserve a stunningly diverse landscape that includes wetlands, riparian areas, unique sand dunes, and forested lands topping more than 14,000 feet in elevation. ${ }^{344}$ The FWS has assumed a leadership role and adopted a San Luis Valley Conservation Area Land Protection Plan that covers more than 4 million acres. The Plan sets a goal of acquiring interests in nearly 300,000 acres of ranchland to protect more fully the valley's fragile ecosystems and at-risk species. ${ }^{345}$ Working in tandem, the different federal land management agencies, with help from Congress and various land trusts, are stitching together the diverse San Luis Valley landscape to reflect a growing and farsighted commitment to nature conservation.

\section{American Prairie Reserve}

In northeastern Montana, the American Prairie Reserve represents an innovative private conservation initiative that is making substantial progress toward its vision for a 3.5-million-acre public-private grassland conservation area

341. Great Sand Dunes National Park and Preserve Act of 2000, 16 U.S.C. $\S \$ 410 h h h-410 h h$ 9 (2012); see also Michael M. Geary, Sea of Sand: A History of Great Sand Dunes National Park And Preserve 176-202 (2016) (describing the lead-up to passage of the Act and the ensuing process of converting the monument to a park).

342. Frederick Reimers, Shifting Ground, Nature Conservancy Mag. (May/June 2013), https://perma.cc/5AM4-VRS4.

343. See U.S. Fish \& Wildlife Serv., Land Protection Plan: Sangre De Cristo ConSERVATION Area 2-4, 7 (2012), https://perma.cc/6DLP-2DDE.

344. Id. See generally GEARY, supra note 341, at 104-30.

345. See U.S. Fish \& Wildlife Serv., Land Protection Plan: San Luis Valley ConserVATION AREa 43-44 (2015), https://perma.cc/G7HM-JJ9S; see also U.S. Fish \& WiLdLIFE Serv., Comprehensive Conservation Plan: San Luis Valley National Wildlife Refuge Complex 14-15, 35-36 (2015), https://perma.cc/GGY4-D6HJ (establishing management goals for the wildlife refuges and identifying partnership opportunities). 
to restore plains buffalo and other native species. ${ }^{346}$ The Reserve is engaged in acquiring 500,000 acres of privately owned ranchland nearby the Missouri River in order to encumber these lands with protective conservation easements. Already the Reserve has purchased or leased more than 274,000 acres abutting the 1.1-million-acre Charles M. Russell National Wildlife Refuge and the 378,000-acre Upper Missouri River Breaks National Monument. The BLM and the state of Montana own more than half the other nearby lands, and two large Indian reservations-Fort Belknap and Rocky Boy-are located proximate to the targeted project area, which has been referred to by National Geographic as the "American Serengeti." 347

The Reserve aims "to create and manage a prairie-based wildlife reserve that, when combined with public lands already devoted to wildlife, will protect a unique natural habitat, provide lasting economic benefits, and improve public access to and enjoyment of the prairie landscape." 348 Although industrial activity is prohibited on the acquired private lands, the Reserve promotes and subsidizes wildlife-friendly agricultural practices, seeking to demonstrate how conservation and ranching activities can co-exist in this expansive grassland environment, where very little plowing has ever occurred. ${ }^{349}$ The Reserve's specific management objectives include reintroducing free ranging bison, restoring riparian areas, natural fire regimes, and extirpated prairie dog communities, and maintaining pronghorn and cougar populations. ${ }^{350}$ In short, the American Prairie Reserve initiative represents a pioneering privately funded conservation effort geared toward stitching together public and private lands to promote a bold landscape conservation experiment, designed to sustain and restore this unique prairie grassland ecosystem.

\section{Northwest Forest Plan}

The Northwest Forest Plan, regularly touted as the first major federal foray into the realm of ecosystem management, ${ }^{351}$ represents a significant landscape-level conservation initiative. In late 1991, after years of litigation and

346. For an overview of the American Prairie Reserve and its conservation vision, strategies, and purchases, see American Prairie Reserve, https://perma.cc/Z99K-8NU8.

347. See Dan L. Flores, American Serengeti: The Last Big Animals of the Great Plains 179-82 (2016); Jake Bullinger, Montana Refuge Divides Tribes and Ranchers, HigH Country News (May 29, 2017), https://perma.cc/B35C-Z9DP.

348. Cynthia Logan, American Prairie Reserve, Distinctly Mont. (Mar. 15, 2014), https://per ma.cc/3VLZ-NJQR; Restoring the Prairie, American Prairie Reserve, https://perma.cc/ 4N2D-7728.

349. Todd Wilkinson, A Quiet Revolution Is Sweeping Across the West, Forging a New Approach to Conservation in the 21st Century, 34 PROP. \& ENv'T REs. CTR. ReP. 23 (2015), https://per ma.cc/WUY9-SY6E.

350. See Restoring, supra note 348.

351. See Keiter, supra note 10, at 80; Skillen, supra note 10, at 183. 
congressional intervention, federal courts enjoined timber harvesting across the Oregon, Washington, and northern California federal forest lands in order to protect the northern spotted owl, throwing the region's powerful and economically important timber industry into a crisis. ${ }^{352}$ To resolve this rancorous controversy, President Clinton directed a group of federal scientists to devise an ecosystem management plan for the affected nineteen national forests and seven BLM resource districts, an area encompassing 24 million acres. ${ }^{353}$ The result was the Northwest Forest Plan, which created 18.8 million acres of protected reserves and left only 5.6 million acres open to timber harvesting subject to substantial environmental constraints. ${ }^{354}$ The Plan also established an Aquatic Conservation Strategy designed to restore and maintain the ecological health of the region's watersheds and aquatic ecosystems, which included several overlaying protective designations to safeguard salmon habitat. ${ }^{355}$ Though challenged in the courts, the Plan passed legal muster, ${ }^{356}$ and it has endured for nearly twenty five years, also surviving efforts during the George W. Bush Administration to amend it in order to facilitate more timber sales by reducing its environmental protections. ${ }^{357}$

352. See Seattle Audubon Soc'y v. Robertson, 771 F.Supp. 1081, 1096 (W.D. Wash. 1991), affd sub nom Seattle Audubon Soc'y v. Evans, 952 F.2d 297, 304-05 (9th Cir. 1991); Seattle Audubon Soc'y v. Moseley, 798 F.Supp. 1473, 1484 (W.D. Wash. 1992), affd sub nom Seattle Audubon Soc'y v. Espy, 998 F.2d 699, 705 (9th Cir. 1993); Portland Audubon Soc'y v. Lujan, 795 F.Supp. 1489, 1510-11 (D. Or. 1992), affd sub nom Portland Audubon Soc'y v. Babbitt, 998 F.2d 705, 709-10 (9th Cir. 1993); see also KeITER, supra note 10, at 93-95.

353. On the President's role in addressing the Northwest timber/spotted owl controversy, see Kathie Durbin, Tree Huggers: Victory, Defeat and Renewal in the Northwest Ancient Forest Campaign 199-200 (1996); Stephen Yaffee, The Wisdom of the Spotted Owl: Lessons for a New Century 140-43 (1994).

354. Approximately $30 \%$ of the acreage included in the Northwest Forest Plan was already protected by Congress as a national park ( 6 parks totaling 2.2 million acres), wilderness area, or another protective designation. The Plan allocated the remaining $70 \%$ of the covered acreage as follows: late successional reserves (30\%); matrix (16\%); riparian reserves (11\%); administratively withdrawn areas (6\%); adaptive management areas (6\%); and managed late successional areas (1\%). See Sec'y of Agric. \& Sec'y of the Interior, Record of Decision for Amendments to Forest Service and Bureau of Land Management Planning Documents within the Range of the Northern Spotted Owl 2 (1994).

355. See Sec'y of Agric. \& Sec'y of the Interior, Record of Decision for Amendments to Forest Service and Bureau of Land Management Planning Documents within the Range of the Northern Spotted Owl, supra note 354, at 9.

356. Seattle Audubon Soc'y v. Lyons, 871 F.Supp. 1291 (W.D. Wash. 1994), affd sub nom. Seattle Audubon Soc'y v. Moseley, 80 F.3d 1401 (9th Cir. 1996).

357. See, e.g., Conservation Nw. v. Sherman, 715 F.3d 1181 (9th Cir. 2013); Conservation Nw. v. Rey, 674 F.Supp.2d 1232 (W.D. Wash. 2009); Pac. Coast Fed. of Fishermen's Ass'ns v. Nat'l Marine Fisheries Serv., 482 F.Supp.2d 1248 (W.D. Wash. 2007); Nw. Ecosystem All. v. Rey, 380 F. Supp.2d 1175 (W.D. Wash. 2005). For an overview of the Bush Administration's efforts to revise the Northwest Forest Plan and the ensuing litigation, see Robert B. Keiter, Breaking Faith with Nature: The Bush Administration and Public Land Policy, $27 \mathrm{~J}$. 
Driven by science and law, the Northwest Forest Plan represents an expansive, landscape-scale, administrative initiative designed to sustain the northern spotted owl population, ${ }^{358}$ other at-risk species, and the region's old-growth ecosystems. Although its protections are less secure than a congressional designation, the Plan serves as a model for interagency, ecosystem-based management. With the blessing of existing law, it has transformed the region's federal forest lands into a major species-based experiment in large-scale nature conservation.

\section{Sierra Nevada Ecosystem}

The Sierra Nevada mountain range extends nearly the length of California and covers more than 24,000 square miles, representing an exceptional natural setting in the nation's most populated state. Though originally viewed as a cornucopia of commercial resources-gold, silver, timber, water, and grasslandsthe Sierras have come to be valued more for their natural attributes, particularly as a life-sustaining water source and as a recreation and tourism amenity. Several large national parks, including Yosemite, Sequoia, Kings Canyon, and Lassen, cover more than 1.6 million acres in the Sierras, and more than twenty designated wilderness areas extend along the range, reflecting a strong commitment to nature conservation. During the early 1990s, noting that the Sierra range was in poor ecological health and fearing that a declining California spotted owl population might trigger an endangered species listing, Congress requested a "scientific review of the remaining old growth in the national forests of the Sierra Nevada in California, and for a study of the entire Sierra Nevada ecosystem by an independent panel of scientists, with expertise in diverse areas related to this issue." ${ }^{359}$ Dubbed the Sierra Nevada Ecosystem Project, the scientists found that the region's eleven national forests had been substantially

LAND, Resources \& EnvTL. L. 195, 224-29 (2007). In fact, timber sales have rarely met the Plan's original expectations, prompting numerous mill closures and industry-led efforts to promote more sales. Jack Ward Thomas et al., The Northwest Forest Plan: Origins, Components, Implementation Experience, and Suggestions for Change, 20 Conservation Biology 277, 284 (2006).

358. Despite the Forest Plan protections, the northern spotted owl population continues to decline, largely due to incursion by the more aggressive barred owl that is overtaking its habitat in the region's old growth forest ecosystems. U.S. Fish \& WildLife SERV., ExPERIMENtal Removal of Barred Owls to Benefit Threatened Northern Spotted Owls Final Environmental Impact Statement (2013); Craig Welch, The Spotted Owl's New Nemesis, Smithsonian Mag. (Jan. 2009), https://perma.cc/2MX2-T4VJ.

359. Don C. Erman \& The Sierra Nevada Ecosystem Project Team, Status of the Sierra Nevada: The Sierra Nevada Ecosystem Project, U.S. Geological Survey (1997), https://perma.cc/ 9U9A-P3HN. 
altered by historic logging, fire suppression, and grazing practices, putting species relying on old growth habitat at increased risk. ${ }^{360}$

In response, the Forest Service undertook a comprehensive EIS process resulting in a 2004 Framework document amending the existing forest plans. ${ }^{361}$ The Framework, having withstood a multi-faceted court challenge, ${ }^{362}$ reflects a federal commitment to manage the eleven Sierra Nevada national forests on an ecosystem scale to restore ecological sustainability by protecting old growth forest ecosystems and riparian areas, maintaining viable California spotted owl populations, and establishing an effective fuels treatment program. The resulting forest plan amendments have largely eliminated commercial timber harvesting across the Sierra range, while focusing the remaining cutting-mostly fuels treatment work-on the three northernmost forests, long the principal timber producers. ${ }^{363}$ To comply with a court order from the earlier litigation, ${ }^{364}$ the Forest Service is presently revising three forest plans under the Agency's new 2012 planning regulations, which has included a bioregional assessment that further highlights the expanded scale of the Agency's current resource management efforts. ${ }^{365}$ Much like the Northwest Forest Plan, the Sierra Nevada Forest Plan Amendments represent an expansive, administratively-driven, landscape-

360. See Status of the Sierra Nevada: The Sierra Nevada Ecosystem Project: Final Report to Congress (Don C. Erman ed., 1997), https://perma.cc/B4A3-6SXE. For background on the Sierra Nevada forest management controversy, see KEITER, supra note 10, at 274-84; Dave Owen, Prescriptive Laws, Uncertain Science, and Political Stories: Forest Management in the Sierra Nevada, 29 Ecology L.Q. 747 (2002); Lawrence Ruth, Conservation on the Cusp: The Reformation of National Forest Policy in the Sierra Nevada, 18 UCLA J. ENVTL. L. \& POL'Y 1 (1999/2000).

361. The EIS process actually involved two separate EISs, one completed in 2001 that substantially limited logging on the Sierra Nevada forests, and a supplemental EIS completed in 2004 that noticeably loosened the earlier logging restrictions. See U.S. Forest SerV., SIerra Nevada Forest Plan Amendment Final Supplemental Environmental Impact Statement Record of Decision (2001); U.S. Forest Serv., Sierra Nevada Forest Plan Amendment Final Supplemental Environmental Impact StATEMENT Record of Decision (2004), https://perma.cc/UJ5T-YWXP. For an overview of this forest plan amendment process, see Keiter, Breaking Faith with Nature, supra note 357 , at $229-33$.

362. The considerable litigation history involving the Sierra Nevada Service's forest plan amendment process is recounted in Pacific Rivers Council v. U.S. Forest Service, 942 F.Supp.2d 1014, 1016-17 (E.D. Cal. 2013), and Sierra Forest Legacy v. Sherman, 951 F.Supp.2d 1100, 1104-05 (E.D. Cal. 2013).

363. U.S. Forest Serv., U.S. Dep’t of Agric., Sierra Nevada Forest Plan Amendment: Management Review and Recommendations 10 (2003); Katie Schaefer, Ninth Circuit Cuts Down Sierra Nevada Forest Plan, 39 Ecology L.Q. 659, 660 (2012).

364. See Pac. Rivers Council, 942 F.Supp.2d at 1034; Sierra Forest Legacy, 951 F.Supp.2d at 1116.

365. See U.S. Forest Serv., U.S. Dep't of Agric., Final Sierra Nevada Bio-Regional Assessment 5-14 (2014); see also U.S. Forest Serv., U.S. Dep’t of Agric., PSWGTR-237, Managing Sierra Nevada Forests, (Malcolm North ed., 2012) (analyzing the application of ecosystem management principles to the Sierra Nevada forests). 
scale initiative that has effectively knitted together the eleven national forests of this world-renowned mountain range in a common commitment to promoting forest ecosystem health and nature conservation-a mission not too unlike the one pursued by the region's national parks and wilderness areas.

\section{Elsewhere on the Public Domain}

In addition to these extensively protected public land complexes, other predominantly federal landscapes in the West and elsewhere are also serving important nature conservation purposes. In north central New Mexico, with the recent designation of the Valles Caldera National Preserve alongside the Bandelier National Monument and the Santa Fe National Forest, ${ }^{366}$ a growing complex of national park and forest lands are now each being managed with an emphasis on wildlife habitat, ecological integrity, and public recreation. ${ }^{367}$ In southern Utah, Bryce Canyon National Park, Grand Staircase-Escalante National Monument, Glen Canyon National Recreation Area, and Capitol Reef National Park constitute a multi-million-acre complex of federally protected lands that contain manifold biological, scenic, cultural, historical, and recreational values. ${ }^{368}$ In southeastern Utah, the recent Bears Ears National Monument designation partially abuts Canyonlands National Park and Glen Canyon National Recreation Area, creating another large complex of federally protected lands. ${ }^{369}$ In northern Washington state, the 504,700 acre North Cascades National Park is flanked by two Park Service-administered national recreation areas, multiple wilderness areas, and extensive national forest lands, as well as provincial parks and recreation areas on the Canadian side of the international border, creating what has been referred to as the Greater North Cascades Ecosystem. ${ }^{370}$

366. See 16 U.S.C. $§ 698 \mathrm{v}-11$ (2012) (Valles Caldera National Preserve); 16 U.S.C. $§ 698 \mathrm{v}-2(\mathrm{~b})$ (2012) (Bandelier National Park). See generally Melinda Harm Benson, Shifting Public Land Paradigms: Lessons from the Valles Caldera National Preserve, 34 VA. ENVTL. L.J. 1 (2016).

367. See U.S. Forest Serv., U.S. Dep't of Agric., Findings from the Final Assessment: Twelve Focus Areas and Need for Change Statements (2016), https://perma.cc/ L8DY-9M6Z; U.S. Forest Serv., Santa Fe National Forest Plan Final AssessMENT REPORT (2016), https://perma.cc/RS7K-RUKB.

368. But see supra note 334 and accompanying text.

369. Proclamation No. 9558, Establishment of the Bears Ears National Monument, 82 Fed. Reg. 1139 (January 5, 2017). But see Proclamation No. 9681, Modifying the Bears Ears National Monument, 82 Fed. Reg. 58,081 (Dec. 4, 2017) (reducing the size of Bears Ears National Monument from 1.35 million acres to roughly 202,000 acres, establishing two small new units largely detached from Canyonlands National Park and Glen Canyon National Recreation Area, and thus fragmenting what had been an integrated protected landscape under the original national monument proclamation).

370. See generally North Cascades, North Cascades Inst., https://perma.cc/442T-MTWZ; R. Edward Grumbine, Ghost Bears: Exploring the Biodiversity Crisis 58-59 (1992). 
Elsewhere, south Florida's expansive Everglades ecosystem, which includes Everglades National Park, Biscayne Bay National Park, Big Cypress National Preserve, and several National Wildlife Refuge units, is the target of a massive federal-state ecological restoration effort designed to restore natural stream flows and to sustain the region's native vegetation and wildlife populations. ${ }^{371}$ The southern Appalachian Mountains, home to two large national parks, several national forests, wilderness areas, and national wildlife refuges, provide an opportunity to engage in landscape-scale planning in order to protect the region's rich biodiversity and important watersheds, while also meeting recreational and other needs of this heavily populated region. ${ }^{372}$ In central Maine, establishment of the 87,500-acre Katahdin Woods and Waters $\mathrm{Na}$ tional Monument adjacent to Baxter State Park protects critical lower elevation lands and enhances the area's wilderness character. ${ }^{373}$ Although the list could go on, these mounting examples of legally protected federal land complexes further illustrate the broader trend toward landscape-scale conservation across the nation. ${ }^{374}$

$* * * * *$

These diverse protected public land complexes, despite the ad hoc character of their origins and legal designations, share an indisputable common attribute: Each represents an emergent federal commitment to large-scale nature conservation. In a world increasingly beset by climate change impacts and ecological wounds, there is an evident and compelling need to connect these complexes into a more formal network to coordinate an innovative, landscape-scale national conservation effort that also addresses connectivity concerns and resto-

371. On the Everglades ecosystem restoration, see for example, Michael Grunwald, The Swamp: The Everglades, Florida, and the Politics of Paradise (2007); William R. Lowry, Repairing Paradise: The Restoration of Nature in America's National Parks (2009); Kelly F. Taylor, Note: A Trickle of Cash for the River of Grass: Federal Funding of Comprehensive Everglades Restoration, A Critique and a Proposal, 64 U. Miami L. Rev. 1407 (2010).

372. See Appalachian Landscape Conservation Coop., 2014 Annual Report (2014), https://perma.cc/MM86-R4JX; Hugh Irwin et al., S. Appalachian Forest Coal., Return the Great Forest: A Conservation Vision for the Southern Appalachians (2002); Brownie Newman et al., Southern Appalachian Wildlands Proposal, Wild EARTH (Special Issue) 46 (1992); see also supra notes 122-24 and accompanying text (describing the Appalachian National Trail and its potential role as a connective corridor).

373. Proclamation No. 9476, 81 Fed. Reg. 59,121 (Aug. 24, 2016); Richard Perez-Pena, Obama Designates National Monument in Maine, to Dismay of Some, N.Y. Times (Aug. 24, 2016), https://perma.cc/YR64-EVFS.

374. To be sure, several large-scale conservation initiatives, including the Interior Columbia Basin Ecosystem Management Project and the Northern Rockies Ecosystem Protection Act, have not materialized due to agency recalcitrance and congressional resistance. See KeITER, supra note 10, at 162-69, 191-92. Other initiatives, like the Yellowstone to Yukon project, have enjoyed some limited success. See id. at 191-92. 
ration opportunities. It is, in other words, time to consider a comprehensive legislative approach to nature conservation at the federal level, one that weaves these diverse protected land complexes into a coherent network of protected areas that also embraces the many innovative private conservation efforts that have sprouted across the nation.

\section{B. A National Conservation Network: Conceiving a Statutory Framework}

A National Conservation Network Act ("NCN Act") would not only formalize these manifold nature conservation initiatives, but it would better enable the land management agencies to coordinate these efforts across the landscape. It would highlight the considerable progress already underway in myriad locations as outlined above, reinforcing the vital concept of landscape-scale conservation and thus further breaking down the prevailing yet inadequate enclave model of nature conservation. It would also promote a further shift in agency culture to ensure that resource management decisions were fully sensitive to conservation science and related concerns. As we have seen, the notion of a formal national conservation system is not a new idea, ${ }^{375}$ nor is the notion of landscape conservation. ${ }^{376}$ In fact, Congress has already given the nation several different nature conservation systems, plainly recognizing the value of formally incorporating our national parks, wilderness areas, and wildlife refuges into coherent albeit separate systems. An NCN law represents the next logical step in our ongoing efforts to safeguard the nation's natural heritage.

The basic framework for an NCN Act is straightforward and need not involve placing additional federal acreage in a protected status. ${ }^{377}$ In brief, the proposed NCN law would operate as an overlay on existing designations, assembling national parks, wilderness areas, and the like into a new NCN, but without altering the responsible managing agency or the legal mandates presently governing each area. ${ }^{378}$ Applying across all federally protected lands, the

375. See supra notes $191-258$ and accompanying text.

376. See supra notes 191-197 and accompanying text.

377. The 2009 congressional legislation establishing the BLM's NLCS provides a partial model for the legislative proposal put forth here. 16 U.S.C. $§ 7202$ (2012). Like the NLCS legislation, the proposed NCN law is intentionally rather modest, recognizing the political realities surrounding any legislative proposal that might be perceived as expanding the protected acreage on the federal public lands-always a "hot button" issue when Congress is considering wilderness or other legislation that would foreclose industrial activities on multiple-use public lands. See, e.g., Allin, supra note 7, at 113-16 (describing political opposition to passage of the Wilderness Act). See generally Thomas M. Rickart, Wilderness Land Preservation: The Uneasy Reconciliation of Multiple and Single Land Management Policies, 8 B.C. Envtl. Aff. L. Rev. 873 (1980).

378. As a statutory overlay, the proposed law would basically function like a "wilderness" designation under the Wilderness Act. 16 U.S.C. § 1133(a) (2012) ("the purposes of this Act are ... supplemental to the purposes for which national forests and units of the national park 
NCN law would direct the federal agencies to identify and define individual protected area complexes ("PACs") for conservation management purposes. Recognizing that each PAC (or landscape) is unique, the law would direct the responsible agencies to develop locally tailored management arrangements, institutions, and strategies for each complex. To realize the full conservation value of a designated PAC, the law would include coordination, public participation, and perhaps advisory committee requirements for resource planning and management decisions among the responsible agencies. It would afford nonfederal landowners and conservation easement owners the opportunity to voluntarily "affiliate" with the federal conservation network, thus potentially encompassing both public and private lands in the landscape conservation effort. Other features include the opportunity to identify and designate wildlife corridors as part of the network and new "national restoration areas" to reclaim degraded public lands that have potential conservation value. The goal is not to standardize management of any particular landscape, but to enhance and institutionalize federal nature conservation efforts by formally extending them to the landscape level and by empowering the federal agencies and other landowners to work together with an eye on the larger landscape.

As is true with any systemic law governing the public lands, the proposed NCN Act should contain a purpose statement, scope provision, and management standards. The statutory purpose can be stated succinctly: To conserve, protect, and restore, through coordinated landscape-level planning and management, the nation's invaluable natural heritage as represented by its formally protected lands, including the outstanding ecological, wildlife, scientific, recreational, and cultural values represented therein, for the benefit of current and future generations. The components of the network would include national park system units, designated wilderness areas, national wildlife refuges, the BLM's NLCS lands, wild and scenic river corridors, the national trail system, and national forest roadless areas, ${ }^{379}$ as well as voluntarily affiliated non-federal (state, tribal, and private) lands dedicated to nature conservation. For management standards, the law should specify that the lands included in the network will be managed in accordance with applicable laws relating to that particular component and to achieve the purposes underlying the NCN. In short, the proposed NCN Act would explain the rationale for establishing a new national network for federally protected lands, create a new PAC designation, endorse existing management standards, promote coordinated landscape-scale planning and management among the responsible agencies, and enable non-federal lands

and national wildlife refuge systems are established and administered”); $i d$. § 1133(b) ("each agency administering any area designated as wilderness shall be responsible for preserving the wilderness character of the area").

379. Some Department of Defense lands also might merit inclusion in the NCN, but that should be left to the discretion of military officials, whose first duty is to ensure military preparedness. 16 U.S.C. $§ 670 \mathrm{a}(\mathrm{a})(3)(\mathrm{A})(2012)$; see supra notes $125-132$ and accompanying text. 
devoted to nature conservation to affiliate with the network to expand the conservation effort.

To promote landscape scale management, the NCN law should direct the federal land management agencies to identify individual PACs and then collaboratively manage them. ${ }^{380}$ For the lands included within the network, the responsible agencies would be required, through a public process, to identify manageable landscape-scale PACs, such as the GYE, the California Desert Conservation Area, or the Crown of the Continent Ecosystem. ${ }^{381}$ Given that local conditions will vary among the different PACs, the agencies should be empowered to devise interagency management arrangements best-suited to promoting landscape planning and decision-making for each PAC. Congress, generally limited in its knowledge about resource conditions and conservation strategies, should delegate the responsibility for identifying the PAC landscapes to the agencies, who can draw upon their knowledge, experience, and interested constituencies to target appropriate areas for inclusion in the PACs. The existing interagency LCCs as well as other established multi-agency arrangements, such as the Greater Yellowstone Coordinating Committee and the Crown Managers' Partnership, ${ }^{382}$ suggest that the agencies can be entrusted with this responsibility. If Congress believes some additional guidance is necessary, it could establish a national advisory committee to oversee the PAC designation process and provide for public input. Or it can just set forth examples of potential PACs in the relevant committee reports and legislative history.

Meaningful interagency coordination is essential to effective landscapelevel planning and management of the identified PACs. The NCN law should thus include a rigorous and enforceable coordination provision requiring the responsible agencies to work together toward common conservation objectives on the PAC landscapes. ${ }^{383}$ Such an interagency coordination provision should not be particularly contentious; the federal land management agencies already have an independent legal responsibility to safeguard these protected lands, ${ }^{384}$ and each agency also has general coordination obligations under existing law or

380. Alternatively, as in the Wilderness Act of 1964, Congress could identify initial NCN complexes, such as the GYE or Crown of the Continent Ecosystem, and direct the land management agencies to identify other potential areas with similar characteristics for inclusion in the network. See 16 U.S.C. § 1132(a) (2012) (designating national forest lands classified as "wilderness," "wild," or "canoe" as wilderness areas).

381. Once identified by the agency as a protected NCN complex or landscape, that designation would be formalized either in agency land use plans or through formal rulemaking to establish the NCN complex or landscape. The Forest Service's roadless area rule provides an example of how this might work. See supra notes 94-107 and accompanying text.

382. See supra notes 300-301, 316 and accompanying text.

383. See Robert L. Fischman, Leveraging Federal Land Plans into Landscape Conservation, 6 GeO. WASH. J. ENERGy \& ENVTL. L. 46, 54 (2016) (recommending inclusion of landscape-scale collaboration and integration in individual federal land-use planning processes).

384. See supra notes 18, 49-53, 60-62, 88-89, 101-107 and accompanying text. 
policy. ${ }^{385}$ But the coordination provisions found in the NFMA, FLPMA, and other public land planning laws have not always proven effective in generating conservation-sensitive land management plans, as evidenced by the BLM's decision to initiate a Master Lease Plan process to ensure, among other things, that agency managers take account of nearby national parks and other preserved lands when making oil and gas leasing decisions. ${ }^{386}$ More often than not, adjacent land managers will comment on a neighboring agency's land management plan, and that comment marks the beginning and end of any serious coordination effort. ${ }^{387}$ In some instances, though, neighboring land managers have been included under NEPA regulations in a sister agency's planning process as a cooperating agency, giving that manager a more substantial and ongoing role in the decision process. ${ }^{388}$ The challenge is to devise an effective and efficient landscape network coordination provision, one that will enable managers to fully understand how the affected landscape — or PAC—is connected together for conservation purposes and to develop resource management plans that address conservation concerns at this scale.

Several options merit consideration as a means to promote harmonious, interagency planning for NCN lands. One option is to require the land managers responsible for each PAC to jointly prepare a regional or landscape-level plan, one that would overlay existing resource management plans and then guide resource management decisions when addressing cross-boundary issues

385. See supra notes 233-235 and accompanying text.

386. Bureau of Land Mgmt., Instruction Memorandum 2010-117, Oil and Gas Leasing Reform - Land Use Planning and Lease Parcel Reviews (2010), http:// perma.cc/T3CS-X635.

387. See Bureau of Land Management's Planning 2.0 Initiative: Hearing Before the Subcomm. on Public Lands, Forests, and Mining of the S. Comm. on Energy and Natural Resources, 114th Cong. 2nd Sess. 39 (2016) (statement of Prof. Mark Squillace). See generally Michael C. Blumm \& Marla Nelson, Pluralism and the Environment Revisited: The Role of Comment Agencies in NEPA Litigation, 37 VT. L. REv. 5 (2012) (examining how courts treat other agencies' comments in NEPA-based litigation); Michael C. Blumm \& Stephen R. Brown, Pluralism and the Environment: The Role of Comment Agencies in NEPA Litigation, 14 HaRV. ENVTL. L. Rev. 277 (1990) (examining the impact comments from other agencies have in NEPA-based litigation).

388. See 40 C.F.R. $\S \S 1501.6,1508.5$ (2016). NEPA also requires federal agencies preparing an EIS to "consult with and obtain the comments of any Federal agency which has jurisdiction by law or special expertise with respect to any environmental impact involved. 42 U.S.C. § 4332(C) (2012); see also Bureau of Land Mgmt., A Desk Guide to Cooperating Agency Relationships (2005), https://perma.cc/4HT8-7ZJG (explaining cooperating agency status, opportunities, and practices); Helen Leanne Serassio, Legislative and Executive Efforts to Modernize NEPA and Create Efficiencies in Environmental Review, 45 Tex. ENVTL. L.J. 317, 341-42 (2015) (assessing the role of cooperating agencies). 
involving these protected lands. ${ }^{389}$ Alternatively, the agencies could individually prepare landscape conservation plans at the unit level, much like they currently prepare separate travel management plans, energy leasing plans, wilderness management plans, and the like. ${ }^{390}$ To ensure that these unit-level landscape conservation plans are coordinated across the PAC, the law should require the affected neighboring land managers to review and "sign off" on each plan, giving them a meaningful consultation role that would require the planning agency to respond to any objections that were raised. ${ }^{391}$ Another option is to require that a "landscape coordination statement" accompany agency planning and management decisions, documenting the agency's PAC coordination efforts and responding to any concerns raised during the decision process. Further, the landscape coordination effort can be advanced through joint interdisciplinary teams composed of representatives from the affected federal land management agencies as well as state, tribal, and local officials with resource management responsibilities in the designated PAC landscape. Final decision authority, of course, must remain with the responsible agency, ${ }^{392}$ but only after it has documented its coordination efforts, explained how it has taken account of landscape-level conservation concerns raised by its counterparts, and responded directly to any concerns voiced by adjacent land managers or others. Whichever option is selected, the coordination process should be mandatory and enforceable through administrative appeal processes and judicial review to ensure accountability among the responsible agencies.

Given the important role communities, conservation organizations, motivated individuals, and scientists have long played in establishing and safeguarding our diverse protected lands, the proposed NCN law should afford them a role in the various PACs that make up the larger conservation network. The $\mathrm{NCN}$ law should therefore require public participation in the PAC identifica-

389. Several examples of regional land use plans already exist, including the Northwest Forest Plan and the Sierra Nevada Forest Plan Amendments. See supra notes 351, 352-365 and accompanying text.

390. See Norton v. S. Utah Wilderness All., 542 U.S. 55, 67-72 (2004) (describing the multilevel BLM resource management planning process); 2 George C. Coggins \& Robert L. Glicksman, Public Natural Resources Law § 17:26 (BLM “tiering”) (2d ed. 2012); § 17:35 ("tiering" and cumulative impacts); Robert L. Glicksman, Wilderness Management by the Multiple Use Agencies: What Makes the Forest Service and the Bureau of Land Management Different?, 44 EnvTL. L. 447, 479-84 (2014) (describing the Forest Service and the BLM planning processes).

391. Cf. 43 U.S.C. $§ 1712(c)(9)$ (2012) (establishing detailed coordination procedures for BLM resource management plans that includes "resolving, to the extent practical, inconsistencies between Federal and non-Federal Government plans").

392. U.S. Telecom Ass'n v. FCC, 359 F.3d 554, 565-66 (D.C. Cir. 2004); see Nat'l Parks \& Conservation Ass'n v. Stanton, 54 F.Supp.2d 7, 20 (D.D.C. 1999). 
tion process, ${ }^{393}$ which could also include a provision enabling individuals or organizations to petition for establishment of a PAC. ${ }^{394}$ The PAC landscape planning process, consistent with NEPA requirements, ${ }^{395}$ would ensure public involvement opportunities, enabling interested parties to comment on the plans and interagency coordination efforts. The proposed NCN law could also provide for advisory committees to participate in the establishment and management of individual PACs, ${ }^{396}$ though such committees must be carefully structured to represent an array of interests, local and national as well as economic and environmental. It should also include one or more professional scientists who would bring ecological and other expertise into the PAC identification, planning, and management processes. ${ }^{397}$ Incorporating specific public involvement and advisory committee provisions into the NCN law would not only help to instill landscape conservation perspectives within the responsible agencies, but would also promote accountability among the multiple agencies responsible for individual PACs.

Private and other nonfederal lands often have substantial conservation value, especially in the West where so much riparian habitat is in private hands due to early settlement patterns. The land trust movement has recognized these values as well as the necessity for landscape-scale conservation efforts. ${ }^{398} \mathrm{Be}$ cause nonfederal lands can offer important conservation opportunities, especially when linked with nearby protected public lands, the NCN law should provide state, tribal, and private landowners as well as land trusts an opportunity to "affiliate" with the NCN to advance conservation benefits across each PAC landscape. An "affiliation" decision, given the powerful sentiments surrounding any federal regulatory efforts involving privately owned lands, ${ }^{399}$

393. Such a public participation process could also help to attract private landowners to the landscape conservation effort and perhaps prompt them to "affiliate" with the NCN. See supra notes 379-385 and accompanying text.

394. Cf. 5 U.S.C. $§ 553$ (c) (2012) (enabling individuals to petition for rulemaking under the Administrative Procedures Act); 16 U.S.C. § 1533(b)(3)(A) (2012) (empowering individuals to petition for listing or delisting species under the Endangered Species Act).

395. See 40 C.F.R. $\S 1506.6$ (2017) (requiring public involvement in NEPA processes).

396. For examples of advisory committees established to participate in managing federal protected lands, see 16 U.S.C. § 460nnn-51 (2012) (Steens Mountain Cooperative Management and Protection Area), 16 U.S.C. § 460ddd(j) (2012) (Gila Box Riparian National Conservation Area).

397. Cf. 16 U.S.C. $§ 460 n n n-53$ (2012) (authorizing appointment of a science committee for the Steens Mountain Cooperative Management and Protection Area). See also supra notes 154-181 and accompanying text (explaining the important role scientists are playing in developing nature reserve design and landscape conservation principles).

398. See supra notes 341-350 and accompanying text describing the joint federal-private conservation initiatives afoot in Colorado's San Luis Valley and Montana's Missouri Breaks country.

399. Laurie A. Wayburn, Conservation Easements as Tools to Achieve Regulatory Environmental Goals, 74 Law \& Contemp. Probs. 175, 180-82 (2011), https://perma.cc/6LS3-V2X3; 
would be voluntary. The "affiliate" status, however, would guarantee the landowner an opportunity to participate in the PAC planning and coordination process, and perhaps eligibility for federal funding or technical assistance to facilitate habitat maintenance, ecosystem restoration, or related conservation work. To be eligible for "affiliate" status in the NCN, the property owner must be legally obligated to maintain or restore the affected lands to meet conservation standards comparable to those prevailing on the federally protected lands. Lands encumbered with a conservation easement and state or tribal lands protected by law would readily qualify; other nonfederal lands might qualify depending on the degree of protection they enjoyed. The goal is to augment the federal PAC lands with similarly protected nonfederal lands to enhance landscape-level conservation efforts across the network.

Another essential step toward landscape-scale conservation is to identify and protect connective corridors that would enable wildlife to move safely within the PACs and from one PAC to another. The process of incorporating federally protected lands into PACs should enable agency officials to better understand the larger landscape, including where it is advisable and feasible to link PACs and other protected lands together. State wildlife agencies can-and should-play a role in any wildlife corridor protection effort; they have considerable technical knowledge about population trends, habitat requirements, and migration patterns, much of which has already been captured in State Wildlife Action Plans. ${ }^{400}$ The proposed Wildlife Corridors Conservation Act of 2016 provides a model for identifying, protecting, and managing wildlife corridors on federal and nonfederal lands, including critical coordination, consultation, and funding provisions. ${ }^{401}$ The National Trail System Act, ${ }^{402}$ which has enabled us to stitch together lengthy trail corridors for recreational purposes ${ }^{403}$ offers an-

Julie Ann Gustanski \& John B. Wright, Exploring Net Benefit Maximization: Conservation Easements and the Public-Private Interface, 74 Law \& ConTemp. Probs. 109, 119 (2011); Thompson Jr., supra note 266, at 362-65.

400. See supra note 137 and accompanying text; see also W. Governors' Ass'n, Protecting Wildlife Corridors and Crucial Wildlife Habitat in the West, Policy ResoLUTION (Feb. 27, 2007) (endorsing the establishment of wildlife corridors); W. GoverNORs' Ass'n, Wildlife CorRidors Initiative RePort (2008), https://perma.cc/UG69VWBL (reviewing the establishment and use of wildlife corridors).

401. H.R. 6448, 114th Cong. (2016); see also Robert L. Fischman \& Jeffrey B. Hyman, The Legal Challenge of Protecting Animal Migrations as Phenomena of Abundance, 28 VA. EnVTL. L.J. 173 (2010) (identifying the shortcomings of current legal approaches to protecting wildlife migratory corridors and describing key elements of an effective corridor conservation legal strategy).

402. 16 U.S.C. §§ 1241-1249 (2012).

403. Major, long distance trail corridors include the Appalachian National Scenic Trail, Pacific Crest National Scenic Trail, and Continental Divide National Scenic Trail. See supra notes 117-124 and accompanying text for additional discussion of national trails and their potential role in landscape conservation efforts. 
other model for this wildlife corridor provision. Where a connective corridor opportunity is identified on federal lands, the PAC planning process should consider designating a formal wildlife corridor and adjust management requirements accordingly. Instituting a corridor designation on federally owned lands does not involve acquiring additional public lands; rather, it only entails revising the existing land management plan, as the Bridger-Teton National Forest in Wyoming did when it incorporated a Path of the Pronghorn migration corridor into its forest plan. ${ }^{404}$ Where an identified connective corridor touches upon nonfederal lands, the question will be whether the landowner is amenable to accommodating a wildlife corridor on her property..$^{405}$ If so, then the landowner might seek network "affiliate" status as part of the PAC; if not, then she can simply decline to affiliate, which might prompt a conservation easement purchase proposal for the affected lands. ${ }^{406}$ By offering nonfederal landowners this voluntary "affiliate" status option, the proposed NCN law respects private property rights while enabling sympathetic landowners to engage in a larger landscape conservation effort.

To further advance the nation's nature conservation efforts, the NCN law should also include a provision creating a new "national restoration area" designation option as part of the landscape planning process. Over the years, portions of the public domain have been heavily degraded from previous logging, mining, road construction, or grazing practices, but some of these lands may be situated in ecologically important areas that represent potential wildlife habitat, new ecosystem types, or connective corridors between protected areas. The idea of restoring degraded public lands for conservation purposes is not a new idea. ${ }^{407}$ Several national parks, including Great Smoky Mountains, Shenandoah, and Redwood, were created or expanded from degraded lands, ${ }^{408}$ and

404. See David N. Cherney, Securing the Free Movement of Wildlife: Lessons from the American West's Longest Land Mammal Migration, 41 EnVTL. L. 599, 610-11 (2011).

405. See id. at 611-12; Fischman \& Hyman, supra note 402, at 217-21; see, e.g., U.S. FisH \& Wildlife Serv., Lower Rio Grande Valley: National Wildlife Refuge, https:// perma.cc/GH2B-4UQX (describing the Lower Rio Grande Valley National Wildlife Refuge as a corridor refuge designed to link private lands to facilitate movement of wildlife along a stretch of the Rio Grande River).

406. Of course, the land management agency would also have the option of exercising its eminent domain authority, which would probably only occur if the identified corridor lands were regarded as essential to the conservation effort, and then the landowner would be entitled to compensation.

407. See generally Anthony David Bradshaw \& Michael J. Chadwick, The Restoration of Land: The Ecology and Reclamation of Derelict and Degraded Lands 10 (1980); Bruce Babbitt, Cities in the Wilderness: A New Vision of Land Use in America (2005).

408. See Keiter, To Conserve Unimpaired, supra note 28, at 249-52; see also Runte, supra note 14, at 147-54 (describing the establishment of Redwood National Park); JoHN IsE, Our National Park Policy: A Critical History 248-70 (1961) (describing the origin of eastern national parks). 
most of the eastern and Midwestern national forests were acquired through the Weeks Act after being depleted by timber overharvesting and then restored during the past century to provide important conservation and recreational values. ${ }^{409}$ Under the proposed NCN Act, the landscape planning process for individual PACs affords an ideal opportunity to consider whether impacted multiple-use lands harbor important conservation values, whether they might be restored to an ecologically functional condition, and what role, if any, they might play over time in the NCN. Once identified as a potential "national restoration area," the managing agency would assume responsibility for restoring the area and then integrating it into a nearby PAC. ${ }^{410}$ As an incentive to identify such areas, Congress should make funding available for restoration work, perhaps through an additional fee or royalty on the industries currently engaged in similar extractive or development activities elsewhere on the public lands. ${ }^{411}$ Properly implemented, the national restoration area concept could expand landscape-level conservation opportunities by including heavily impacted lands in the mix, at least when they have broader ecological value and can be returned to an ecologically functional condition.

To be sure, the proposed NCN legislation would be a heavy political lift at any time. Some degree of congressional opposition can be expected to any proposal perceived to be endorsing or expanding federal land protection, ${ }^{412}$ and the current Trump Administration is plainly more intent on promoting energy development on public lands than endorsing new protective designations. ${ }^{413}$ Even

409. See Weeks Act of 1911, 16 U.S.C. §§ 515-21 (2012); Dana \& FAirfaX, supra note 56, at 111-14; William E. Shands \& Robert G. Healy, The Lands Nobody Wanted xii, 120-21 (Conservation Found., 1977).

410. Cf. Keiter, To Conserve Unimpaired, supra note 28, at 249-52 (proposing the national restoration area concept as a means to expand the national park system).

411. See, e.g., Hazardous Substance Superfund, 26 U.S.C. § 9507 (2012); Abandoned Mine Reclamation Fund, 30 U.S.C. $\$ 1231$ (2012); Bart Lounsbury, Digging Out of the Holes We've Made: Hardrock Mining, Good Samaritans, and the Need for Comprehensive Action, 32 Harv. EnvTL. L. Rev. 149, 190-212 (2008).

412. See Ensuring Public Involvement in the Creation of National Monuments Act, H.R. 1459, 113th Cong., 2d Sess. (2014) (proposed legislation that would have effectively prevented the president from designating new national monuments); Jenny Rowland, The Rise to Power of the Congressional Anti-Parks Caucus, CTr. FOR AM. Progress (April 11, 2016), https://per ma.cc/4KWS-QKH5; Conservation Lands Found., Press Release-House Bill Seeks to Prevent New Parks, Land Protections, Conservation Lands, https://perma.cc/37AX-RK4L. Moreover, the Trump Administration has clearly signaled that its agenda is focused on promoting energy development on the public lands and not preserving them. Exec. Order No. 13,783, Promoting Energy Independence and Economic Growth (March 28, 2017); Exec. Order No. 13,792, Review of Designations under the Antiquities Act (April 26, 2017); Sec'y of Interior, Order No. 3348, Concerning the Federal Coal Moratorium (March 29, 2017).

413. Exec. Order No. 13,783, Promoting Energy Independence and Economic Growth, 82 Fed. Reg. 16,093 (proposed Mar. 28, 2017); Exec. Order No. 13,792, Review of Designations Under the Antiquities Act, 82 Fed. Reg. 20,429 (proposed Apr. 26, 2017); see also supra 
proponents of greater federal land protection efforts might balk at the proposal, reluctant to shine light on the extensive acreage now in some form of protected status. They also might note that the proposal, by not seeking to expand existing protected land systems, leaves currently unrepresented or under-represented ecosystems without additional protection. ${ }^{414}$ That said, the case for formalizing the preservationist legacy that has taken shape across the public lands is compelling, tied as it is to contemporary scientific research and deep public support for land protection and nature conservation. Absent some measure akin to the NCN proposal outlined here, the nation is not fully capitalizing on its substantial investment in nature conservation, and it is risking additional federal endangered species listings along with accompanying regulatory restrictions that might be avoided through the coordinated, landscape-scale management approach contemplated here.

Because the proposal does not alter existing designations, land ownership, or management standards, it should not generate internecine conflict within the federal family. The federal land management agencies have all endorsed the principle of landscape conservation, including wildlife corridors and ecological restoration programs, in one form or another. Private landowners can voluntarily "affiliate" with the network, or they can choose not to affiliate without incurring additional obligations. And the proposal should strike a responsive chord with the land trust movement, which regularly coordinates conservation purchases with the federal land management agencies and has strongly supported landscape conservation principles. Moreover, the economic costs associated with the NCN proposal are quite modest, consisting mainly of the expenses attached to the new interagency coordination responsibilities, which could reduce expenditures if the agencies pool their resources to prepare the requisite landscape conservation plans. Whether Congress can be persuaded to endorse the legislative proposal set forth here, the current landscape conservation efforts extending across and beyond the federal estate will not abate, nor will the need for a more structured effort to reap the full benefits of these ad hoc nature conservation initiatives.

notes 84, 144 and accompanying text (explaining that President Trump has substantially reduced the size of two major national monuments).

414. See, e.g., Foreman, Rewilding North America, supra note 177. Because considerable opposition regularly surfaces in Congress to any expansive new protected area proposal involving the public lands, the NCN Act would rely upon the statutory landscape-scale planning requirements to identify potential additions to the existing protected land systems, which might then be formally designated and added to the network when the political situation changes. Rather than bogging down the NCN Act proposal in a protected acreage debate, the goal is to capitalize on the existing systems and to institutionalize landscape-scale planning strategies. 


\section{CONCLUSION}

In sum, a National Conservation Network ("NCN") law represents the next logical step in our ongoing efforts to safeguard the nation's natural heritage in light of the extant threats to our existing protected areas and current scientific knowledge. Long an international leader in nature conservation, the United States has made a substantial commitment to protecting its natural wonders and wildlife resources as reflected in our national park, wildlife refuge, wilderness, and landscape conservation systems, along with other protective designations and the growing land trust movement. With more than 350 million acres of public and private land now enjoying some form of legal protection and with much of that acreage concentrated in de facto protected land complexes, the question is how to fully realize and enhance this national commitment to nature conservation. The answer, according to most knowledgeable observers, is through landscape-scale conservation efforts that connect our ad hoc protected areas together at the ecosystem level and beyond.

The NCN law outlined here would significantly advance our national commitment to nature conservation without prompting radical changes in the agencies, policies, or practices currently in place across the public lands. It acknowledges the dynamic nature of ecological processes and the likely impacts a warming climate will have on the earth's natural systems, both of which transcend the conventional boundaries we have imposed on the landscape. It addresses the need for coordinated landscape-scale conservation in a measured manner that respects existing institutional arrangements and ownership expectations, but would nonetheless capitalize on the extensive conservation accomplishments already in place. Indeed, it relies upon strategies-landscape planning, interagency coordination, voluntary landowner participation, connective corridors, and ecological restoration-that have achieved considerable acceptance and have proven workable at diverse locations across the public domain.

Adoption of the proposed NCN Act would formally legitimize the ad hoc landscape-level conservation initiatives highlighted here, which already enjoy considerable national and local support. Anything less, given the daunting realities of climate change, continued population growth, and unrelenting development pressures, places the nation's existing nature conservation accomplishments at unnecessary risk. It is time, therefore, to transform the country's extensive protected land systems into a new national conservation network that fully capitalizes on its extraordinary conservation legacy. 
Appendix A 415

Federal Land Ownership and Protected Areas

\section{Federal Lands - by Agency \\ (millions of acres)}

\begin{tabular}{|l|c|c|}
\hline \multicolumn{1}{|c|}{ Agency } & Total & Protected Lands \\
\hline U.S. Forest Service & 193 & 95 \\
\hline National Park Service & 84 & 84 \\
\hline U.S. Fish \& Wildlife Service & 95 & 95 \\
\hline Bureau of Land Management & 247 & 36 \\
\hline TOTAL & $\mathbf{6 1 9}$ & $\mathbf{3 1 0}$ \\
\hline
\end{tabular}

\section{Protected Federal Lands - by Designation}

(millions of acres)

\begin{tabular}{|l|c|c|}
\hline \multicolumn{1}{|c|}{ Protected Lands } & Total & Excluding Alaska \\
\hline Wilderness (USFS) & 36.5 & 30.8 \\
\hline National Park System & 84 & 27.8 \\
\hline National Wildlife Refuges* & 95 & 14.4 \\
\hline National Landscape Conservation System (BLM) & 36 & 29.6 \\
\hline Inventoried Roadless Areas (USFS) & 58.5 & 43.85 \\
\hline TOTAL & $\mathbf{3 1 0}$ & $\mathbf{1 4 6 . 4}$ \\
\hline
\end{tabular}

${ }^{*}$ NWRs do not include recent marine reserves.

\section{Protected Federal Lands - Summary* \\ (millions of acres)}

\begin{tabular}{|l|c|c|}
\hline \multicolumn{1}{|c|}{ Federal Land Summary } & United States & Excluding Alaska \\
\hline Federal Land & 629.0 & 387.5 \\
\hline Protected Federal Land & 310.0 & 146 \\
\hline \% of Federal Land Protected & $\mathbf{4 9 . 3 \%}$ & $\mathbf{3 7 . 6 \%}$ \\
\hline
\end{tabular}

* Total acreage can vary between different sources; includes Department of Defense lands. 